\title{
Caracol, Belize, and Changing Perceptions of Ancient Maya Society
}

\author{
Diane Z. Chase ${ }^{1} \cdot$ Arlen F. Chase $^{2}$
}

Published online: 30 December 2016

(C) The Author(s) 2016. This article is published with open access at Springerlink.com

\begin{abstract}
Archaeological research at Caracol, an ancient Maya site that was rediscovered in 1937, has become a major resource in the interpretation and understanding of the ancient Maya. Caracol, in west-central Belize, is situated in a subtropical region once characterized as being unsuitable for the development or maintenance of complex societies, yet it is one of the largest, if not the largest Classic period Maya site in the southern Maya Lowlands, home to over 100,000 people at its height between $\mathrm{AD} 600$ and 700. The investigations at Caracol underscore the utility of long-term archaeological projects incorporating large-scale settlement study that combine excavation with varied research designs and the use of a contextual approach. By employing Maya epigraphic history, traditional archaeology, and modern technology like LiDAR, research at Caracol details the rise, maintenance, and fall of an ancient Maya city, affording a large window into ancient Maya lifeways. Archaeological work provides evidence of sustainable agriculture, a market economy, city planning that included a road system, the impact of warfare on the site's inhabitants, the sociopolitical status of women, the role that archaeology can play in refining written history, and the significance of commemorating the cyclical passage of time to the ancient Maya. This article
\end{abstract}

$\triangle$ Diane Z. Chase

diane.chase@unlv.edu;

http://www.caracol.org

Arlen F. Chase

arlen.chase@unlv.edu;

http://www.caracol.org

1 Office of the Executive Vice President and Provost, University of Nevada, Las Vegas, Box 451002, 4505 S. Maryland Parkway, Las Vegas, NV 89154-1002, USA

2 Department of Anthropology, University of Nevada, Las Vegas, Box 455003, 4505 S. Maryland Parkway, Las Vegas, NV 89154-5003, USA 
summarizes archaeological research efforts at the site by the Caracol Archaeological Project over the last three decades.

Keywords Urbanism · Maya · Mesoamerica · Epigraphy $\cdot$ Classic period

\section{Introduction}

The city of Caracol is one of the largest known ancient Maya archaeological sites. Located in the currently unpopulated Chiquibul Reserve in the western portion of Belize and bordering on Guatemala, Caracol's rediscovery in 1937 was relatively late for the Maya area, especially compared to long-known Maya archaeological sites like Copan (reported in the mid-1500s), Palenque (reported in the mid-1700s), and Tikal (reported in the mid-1800s). Caracol was initially neither well known nor well studied and was largely absent from discussions of Maya prehistory until the late 20th century. However, archaeological research undertaken over the course of the last several decades demonstrates that Caracol was a key Maya city that impacted broader political dynamics during the Classic period (AD 250-900). Likewise, investigations at Caracol have impacted how we think about and research the ancient Maya.

From archaeological data recovered at Caracol, we now know that Maya sites were not merely small centers controlled by the elaborate ritual of a local elite (e.g., Mathews 1991) but rather could be complex urban centers with city planning and heterogeneous populations (e.g., Dahlin et al. 2005; Hutson 2016; Hutson et al. 2008). City size and population numbers at Caracol exceed traditional expectations for a Maya city; the Classic period site was home to at least 100,000 people, with contiguous settlement covering $200 \mathrm{~km}^{2}$ that was integrated through a dendritic causeway system (A. Chase and D. Chase 1994, 1996a, b, 2001a; A. Chase et al. 2011). The size of the city's population has been arrived at through a variety of methods. Traditional settlement pattern work would count the number of structures at a site, multiply these by a factor of five, and then reduce the number for structures deemed to have other uses (e.g., Culbert and Rice 1990). Given the mapped density parameters for the site and its documented spatial extent, as early as 1994 careful calculations that examined the differential distribution of structures and residential units based on mapping and distance from the site epicenter estimated a conservative population of over 100,000 people (A. Chase and D. Chase 1994, p. 5). LiDAR (Light Distance and Ranging) data collected in 2009 were used to document 4,732 elevated residential groups in approximately $160 \mathrm{~km}^{2}$ and estimated an equal number of nonelevated residential groups, confirming the conservative estimate of at least 100,000 people (A. Chase et al. 2011, p. 395). A second LiDAR campaign in 2013 added an additional $40 \mathrm{~km}^{2}$ of more residential groups in the eastern part of the site; the western limit of Caracol remains undefined as settlement continues over the border into Guatemala. While cognizant of other methods for estimating ancient Maya populations that lower traditional estimates (e.g., supplementary material in Scarborough et al. 2012b), we accept the conservative estimate of 100,000 people living at Caracol at its height. 
The inhabitants of Caracol sustained themselves through widespread agricultural terracing interspersed between households (Fig. 1) — techniques that could be used today to enhance agricultural productivity. Community integration of this large population was achieved in a variety of ways visible through settlement and
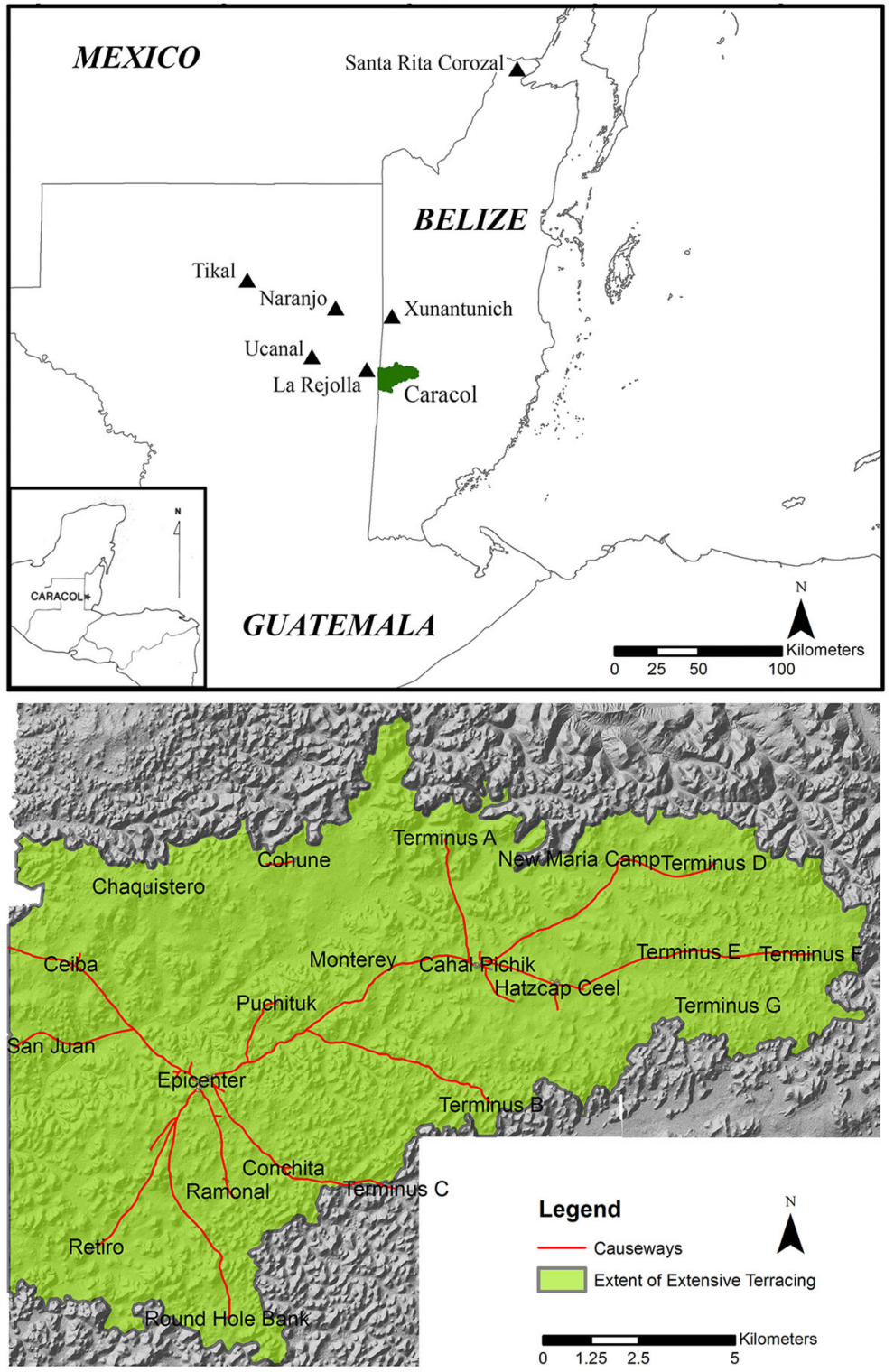

Fig. 1 Location of Caracol in southern Maya Lowlands relative to neighboring sites and the extent of Caracol the city as indicated by road system and the area of continuous terracing and settlement, derived from the 2009 and 2013 LiDAR campaigns 
landscape analysis. Besides the capital investment in agricultural terraces throughout the city (A. Chase and D. Chase 1998a), Caracol's landscape is infilled with regularly spaced residential groups and a series of dendritic roads that integrated the continuously distributed population with the epicenter of the site; the roads also connected the site's inhabitants to an economic system focused on strategically located marketplace plazas where both foreign and local goods were available (A. Chase and D. Chase 2001a, 2015a; A. Chase et al. 2015; D. Chase and A. Chase 2014a). The general settlement pattern consisted of independently situated residential plazuela groups, 50-200 m apart, located within terraced agricultural fields (A. Chase and D. Chase 2007a, 2015a). Although occupied by individual extended families, these residential groups participated in a site-wide shared identity that was manifest in their mortuary ritual: the inhabitants of most residential groups constructed tombs in their eastern mortuary shrines (A. Chase and D. Chase 1996c, 2014; D. Chase and A. Chase 1998, 2004b, 2011), stocked these tombs with imported vessels, and cached specially manufactured pottery vessels in association with these structures (A. Chase 1994, p. 174). Group inhabitants also engaged in personal adornment or beautification in the form of dental modifications (jadeite and hematite inlays, filing), practices that were far more common at Caracol than at its largest neighbor, Tikal, and in many other parts of the Maya area. The widespread distribution of imported goods among the Caracol populace could be viewed as manifestations of wealth (e.g., Smith 1987) and was likely the result of a purposeful management strategy by the elite that focused on symbolic egalitarianism (A. Chase and D. Chase 2009; D. Chase and A. Chase 2006; Pfeffer 1994), in which most Caracol inhabitants had access to the same resources and ritual items, derived at least in part from a functioning market economy (A. Chase and D. Chase 2015a, b; D. Chase and A. Chase 2014a).

Research at Caracol has resulted in the recognition of the positive and negative impacts of warfare on a Maya community. Caracol's population boom and associated prosperity followed its successful wars against Tikal (AD 562) and Naranjo (AD 631) at the beginning of the Late Classic period (A. Chase and D. Chase 1989; D. Chase and A. Chase 2002, 2003a). The negative impact is evident in the archaeological records of the losers; both Tikal and Naranjo evince a loss of their monumental records (Houston 1987), and Tikal's elite mimicked the traditions of dental inlaying found at Caracol; Coe (1990, p. 539) specifically queried "whether people at Tikal with such cultivated dentition may not have been foreigners"; we believe that some were, in fact, from Caracol. Carved stone monuments containing hieroglyphic records at Naranjo were rearranged and dispersed to other sites following Caracol's star-war defeat by that site (Helmke and Awe 2016a, b). While both warfare and environmental change may have played a role in the ultimate collapse of Caracol, research suggests that the situation was far more complicated than these single causal factors (D. Chase and A. Chase 2000; Iannone et al. 2014; Turner and Sabloff 2012); the Terminal Classic social changes at Caracol may provide lessons for our own future.

The Late Classic Maya in the southern lowlands had an interdependent economy in which different sites and zones produced a variety of items and scores of sites were economically cross-linked to one another, most clearly seen in imported 
goods. At the end of the Classic period, however, there was a resurgence of a segregationist ruling dynasty at Caracol that was not community focused. Although the iconography of stone monuments (A. Chase 1985; A. Chase and D. Chase 2015b; A. Chase et al. 1991) and imported ceramics (A. Chase and D. Chase 2004) show they were politically linked to other centers, the Terminal Classic period elite do not appear to have shared imported goods with the broader populace, thus disrupting Caracol's traditional practice of shared identity and symbolic egalitarianism (A. Chase and D. Chase 2007b, 2009). In fact, the site's Terminal Classic ceramics form two status-linked subassemblages, one restricted to the elite and the other used by the bulk of the site's inhabitants (A. Chase and D. Chase 2004). In essence, the $1 \%$ power elite excluded the bulk of Caracol's population from goods and services to which they had previously had access, leading to a breakdown in what had been a functioning socioeconomic system that ultimately resulted in depopulation of the site.

We draw from over 30 years of investigations by the Caracol Archaeological Project, the Belize Institute of Archaeology (IOA), and the Belize governmentsupported Tourism Development Project directed by Jaime Awe. We also build on earlier works by Thompson (1931) at sites in the "Mountain Cow" region of Belize that are within the larger Caracol urban system based on documented causeway connections, Satterthwaite (1951, 1954; Beetz and Satterthwaite 1981) and Anderson $(1952,1958,1959)$ at the site epicenter to gain carved monuments for the University Museum in Philadelphia, and Healy of Trent University (Healy et al. 1983) who documented agricultural terraces within the immediate Caracol site center. We wrote earlier summaries of Caracol shortly after the beginning of the project (A. Chase and D. Chase 1987; D. Chase and A. Chase 1994); additional years of research and data collection have expanded our understanding of Caracol substantially since that time.

\section{History of Work at the Site}

Excavated before epicentral Caracol had ever been reported, the first archaeological investigations in "greater" Caracol were carried out at two intrasite causeway terminus groups during the Classic period. Hatzcap Ceel and Cahal Pichik were early independent centers in the Vaca Plateau that were later incorporated into metropolitan Caracol (see Fig. 1). Thompson (1931; see also J. Morris 2004) investigated both sites in 1928 and 1929, with the collections shipped to the Field Museum of Natural History in Chicago. Hatzcap Ceel and Cahal Pichik entered the literature as independent sites with no direct connection to Caracol proper because of the distance separating the public architectural units. It was not until 1991 for Cahal Pichik and 1995 for Hatzcap Ceel that settlement study made clear that both sites had been incorporated into urban Caracol by the Early Classic period. LiDAR data obtained in 2009 (A. Chase et al. 2011) confirmed that the agricultural terraces and residential groups are continuous and dense between the Caracol epicenter and Cahal Pichik and Hatzcap Ceel and that all three nodes are linked together by 12 m-wide causeways. 
The epicenter of Caracol was completely engulfed by the Chiquibul forest when it was rediscovered in 1937 by a woodcutter who noted standing stone monuments (stelae) and reported them to A. Hamilton Anderson, the Commissioner of Archaeology in what was then British Honduras. Anderson visited the site in 1938 and found eight carved stone monuments as well as sizable mounds and standing architecture. In 1950, Satterthwaite spent three weeks at the site and found 32 monuments, two causeways, and five large plaza areas. As an epigrapher, Satterthwaite was interested in the new inscriptions and returned to Caracol in 1951 and 1953 to record these carved monuments and to map the site, focusing on the 78 structures in the site epicenter where the monuments had been found; at the same time, he and Anderson also excavated two tombs. Anderson (1958, 1959) returned to Caracol in 1955 and 1958, eventually excavating and recording three other tombs. The drawings of Caracol's monuments created by Satterthwaite were published some 30 years later (Beetz and Satterthwaite 1981). A preliminary list of rulers from the Caracol dynasty and their associated deeds, especially pertaining to warfare, were derived from Satterthwaite's drawings, as well as speculation over whether certain Caracol monuments portrayed women or men (Beetz 1980; Beetz and Satterthwaite 1981; Riese 1984; Soza and Reents 1980; Stone et al. 1985).

Healy excavated terraces and residential groups just outside the site epicenter in 1980, providing the first glimpses of the massive investment in agricultural sustainability at the site by the ancient Maya and the settlement density of Caracol. He calculated a population density between 400 (at 25\% occupation) and 1600 (at $100 \%$ occupation rate) per square kilometer in the area in which he worked, approximately $1 \mathrm{~km}$ from the site epicenter (Healy et al. 1983, p. 409), presaging later interpretations. The site did not see extensive or continued research until the onset of the Caracol Archaeological Project (CAP) in 1985.

Current CAP investigations began with a reconnaissance of the site in August 1983 with then Belize Archaeological Commissioner Harriot Topsey (see Pendergast et al. 1995), followed by a more extensive trip in December 1983/January 1984 with the present Director of the Belize Institute of Archaeology, John Morris. The first full season of investigation at Caracol was carried out from January through May 1985 under the auspices of the University of Central Florida. Every year thereafter, we have undertaken a full eight to 20 week season of archaeological investigation at Caracol. CAP investigations have had various foci over the course of the last 30-plus seasons with funding from various agencies (see acknowledgments); these foci include warfare, collapse, settlement, sustainability, neighborhoods, ritual, and status variation. Efforts have focused on understanding both the extent of the site and of ancient Maya land modifications, while also unraveling the history of Caracol's Maya occupation. We have incorporated traditional techniques-excavation, survey, artifact, and hieroglyphic analysis-and modern technology such as LiDAR to better understand Maya adaptation and Caracol's occupation.

CAP investigations have focused both on buildings in the site epicenter and on residential groups that are dispersed over the landscape. The Caracol epicenter is definable by topography and by the spatial demarcations imposed by the Maya themselves (Fig. 2). The western and northern portions of the epicenter are situated 


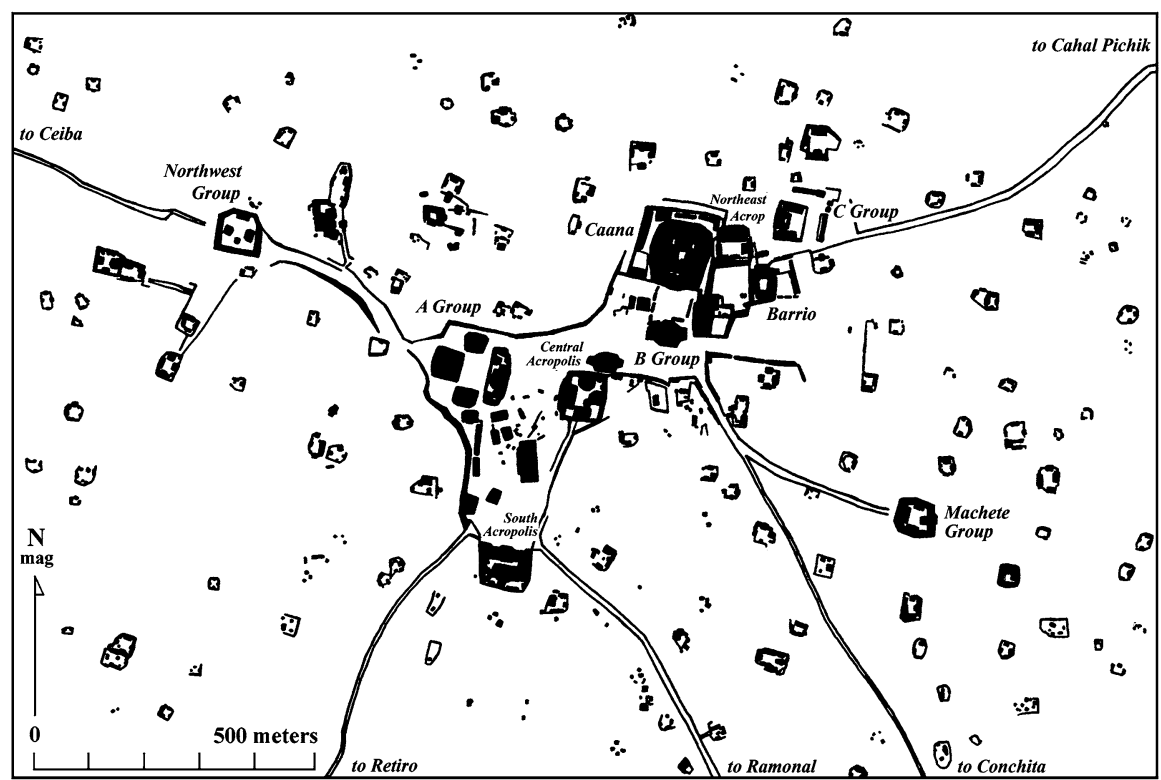

Fig. 2 Map of the constructed architecture (buildings, platforms, roads) in the vicinity of the Caracol epicenter

on high ground that drops off into valleys. The epicenter rests on a platform that is artificially raised $5 \mathrm{~m}$ on average above the surrounding landscape to the north and to the west and that is defined to the east and south by a constructed wall. The northern part of the epicenter, known as the B Group, is dominated by Caana (Ballay 1994), a massive raised architectural complex that served both as the royal palace and for administrative purposes (A. Chase and D. Chase 2001b) (Fig. 3); Caana is unique within the broader Caracol landscape (A. Chase et al. 2011, p. 393) and anchors the northern side of a formal public plaza. The Caracol A Group, west of Caana and also situated around a formal plaza, originally served as an E-Group or horizon-based astronomical observatory; unlike the B Group and Canna, the A Plaza represents nonresidential space. The South Acropolis in the southwestern portion of the epicenter also represents combined residential and nonresidential space. Another major combined residential and nonresidential plaza area exists in the northeastern part of the epicenter, anchored by Structure B64, and is referred to as the C Group; it represents one of the latest public constructions in the epicenter. The South Acropolis and the $\mathrm{C}$ Group may have had sleeping areas, but they do not appear to have housed typical family groups; rather the buildings in these areas were probably used largely for nondomestic purposes having to do with governance and administration. Two residential groups that must have housed long-standing family units also are located within the epicenter: the Central Acropolis and the Northeast Acropolis. A final enclosed plaza unit on the eastern side of the epicenter, named Barrio, contained finely constructed stone buildings on three sides with a northern pyramid that was undergoing construction (but overlay an earlier stone building); 


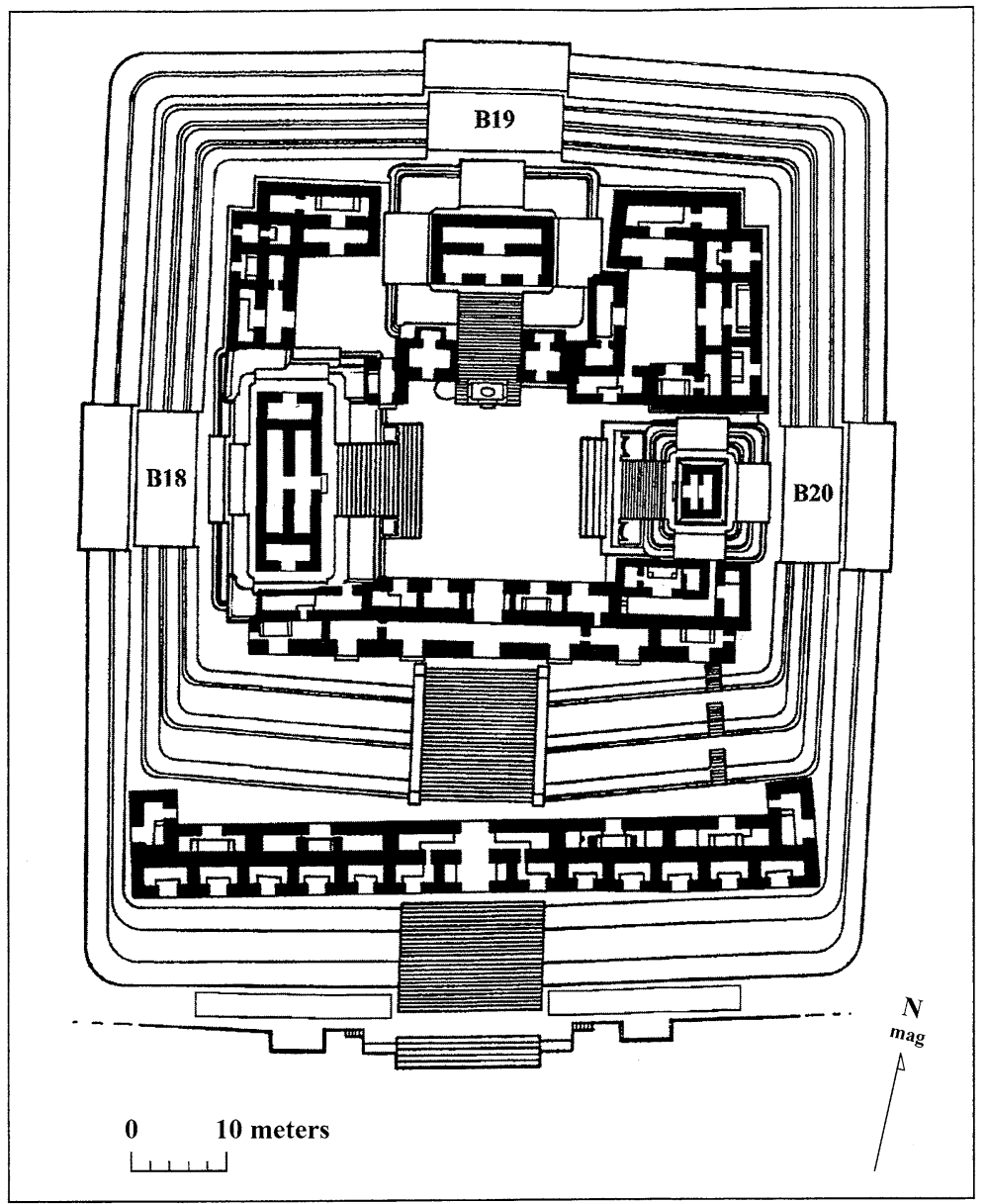

Fig. 3 Plan of Caana, showing the configuration of the vaulted buildings comprising the Late Classic version of this complex

based on the lack of a mortuary structure associated with this group, it is likely that this bounded plaza area was predominantly nonresidential in function and not occupied by a typical extended family household group. The epicenter is also associated with two large, monumental constructed reservoirs, one of which continues to hold water today.

Excavations in the epicentral area have been extensive, with abundant latest-use remains recovered on building floors and numerous buried constructions-tombs, burials, and caches-recovered in association with most of the site's epicentral architecture. Superstructure and substructure building preservation at Caracol is variable; most vaulted roofs have completely collapsed along with the upper walls and roofs of most buildings; likewise, no roof-combs are preserved. However, fallen stucco provides some evidence of external ornamentation that once existed on the majority of these structures. On-floor remains in epicentral buildings include paired 
incense burners (censers) associated with temples (potentially reflecting calendric ritual, similar to paired Postclassic incense burners at Santa Rita Corozal [D. Chase 1985a, b, 1988]); serving vessels, manufacturing debris, and weapons associated with many palace and range buildings (potentially reflecting rapid abandonment); and interior burning in many of Caracol's epicentral buildings at the time of abandonment (potentially reflecting either purposeful destruction or ritual cleansing).

In addition to other interments, 28 Classic period tombs have been excavated in the epicenter; several buildings contain multiple chambers either aligned on a structure axis (e.g., Structure B20 [Fig. 4]) or across the base (e.g., Structure B19 [Fig. 5]). Stable isotope tests on skeletal remains in tombs have shown that elite epicentral residents enjoyed a "palace diet" that was high in maize and meat that differed from the majority of the site's population (A. Chase et al. 2001). Perhaps the most unusual burial in the epicenter was the one sealed deep within the center of the Northeast Acropolis; it likely represents the remains of an individual from Teotihuacan and highlights the importance of Caracol in a broader Mesoamerican context during the Early Classic period; the burial placement, shape, goods, and treatment all mimic the highest elite interments from that central Mexican city (A. Chase and D. Chase 2011). The prominence of women in the site's epicentral tombs reflects their potential importance in the political and social arenas of the Late Classic period (e.g., A. Chase et al. 2008b).

Many epicentral structures also have yielded elaborate ritual caches (see D. Chase and A. Chase 1998); especially intensive caching activities occurred in Structure B19 on Caana and in the plaza in front of Structure B34 in the Northeast Acropolis. Caches placed in public buildings in the site epicenter are of three types:

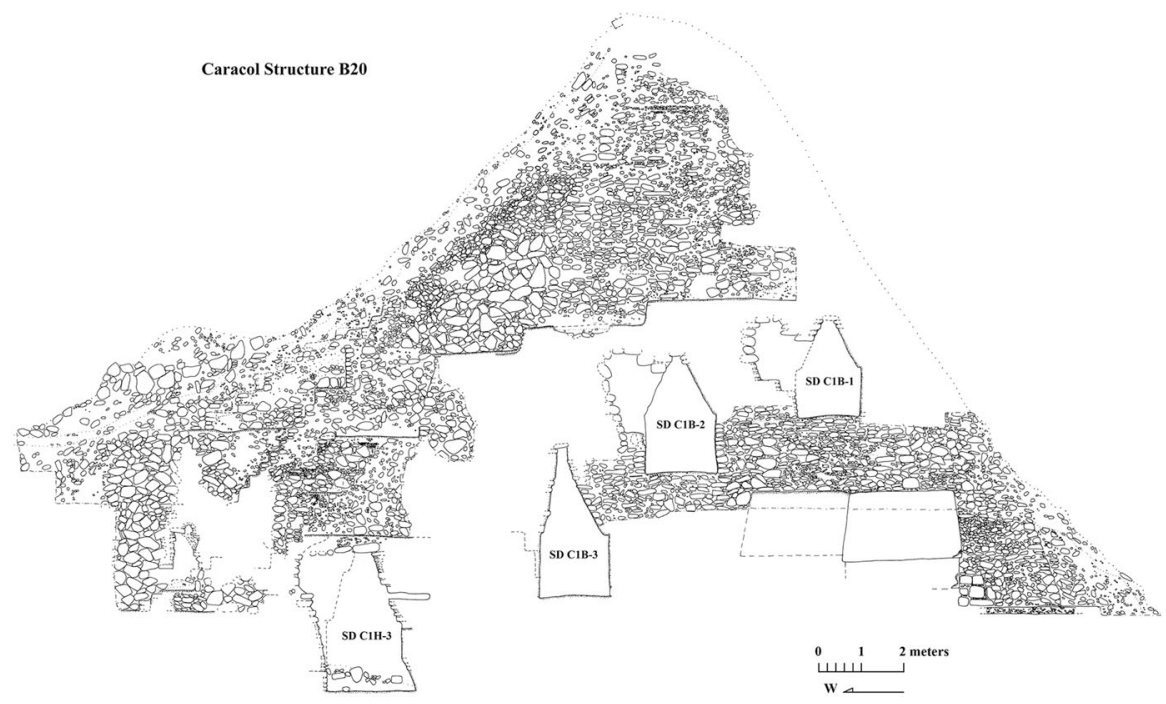

Fig. 4 Section through Structure B20 on the summit of Caana, showing four axial tombs, the earliest of which dates to AD 537 


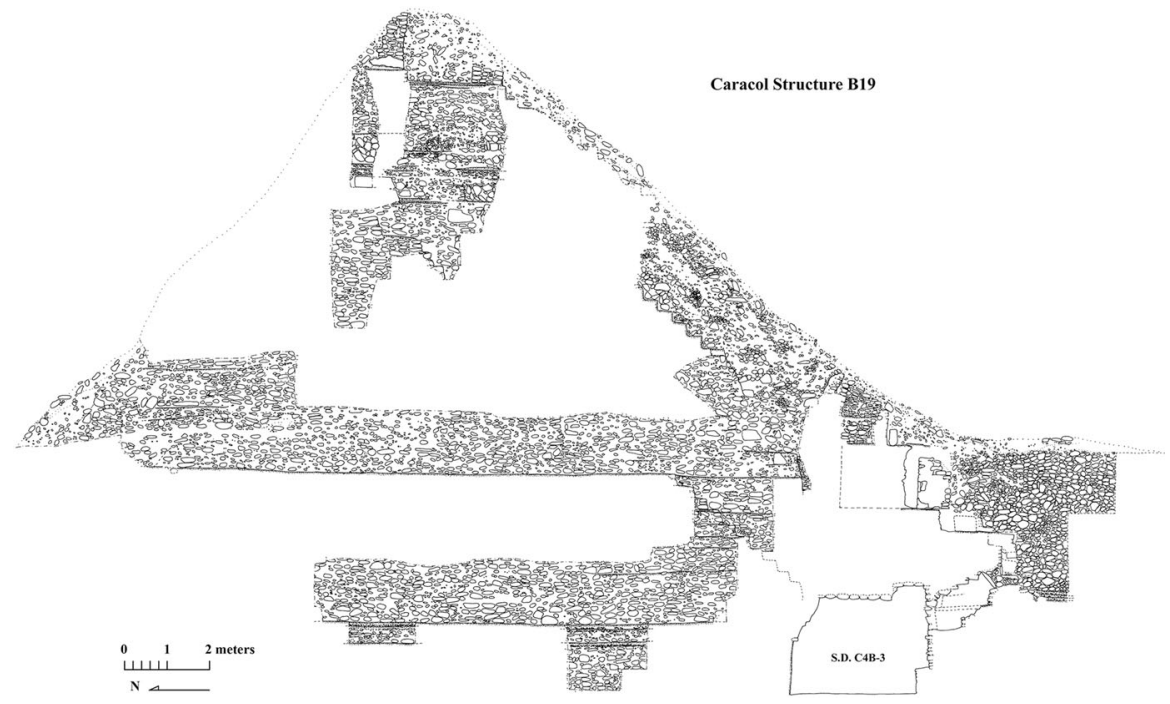

Fig. 5 Section through Structure B19 on the summit of Caana, showing the basal tomb, which dates to AD 614; episodic caching is associated with the deeply buried floors for an earlier version of the latest building on the summit of the substructure

larger pottery or stone containers that house multiple objects; small lip-to-lip bowls that contain human fingers; and objects like Spondylus shells placed directly into structural fill. Epicentral and residential caches likely served slightly varied functions, although all were important in terms of site unification and identity (D. Chase and A. Chase 2004b). Residential groups in the epicenter and in the outlying settlement evince both finger bowl caches and pottery urns, often modeled with a human or bird face, that are sometimes accompanied by obsidian eccentrics or other objects.

Settlement survey has revealed that the site epicenter is directly connected to other public architecture at the site at a distance of 3 to $8 \mathrm{~km}$ from the epicenter; mapping and LiDAR have demonstrated that the settlement is continuously distributed between these hubs or nodes. Some of these outlying architectural entities are connected by causeways to other nodes that extend even farther into Caracol's settlement area; again the residential settlement is continuous. These causeways, residential settlement distribution, and extant agricultural terraces define the city limits of Caracol as extending east almost to the Macal River (see Fig. 1). For example, Cahal Pichik is linked to New Maria Camp, $5 \mathrm{~km}$ to the northeast, and to two other smaller terminus groups to the north and south. New Maria Camp is linked to a small terminus group $2.5 \mathrm{~km}$ to its east; Hatzcap Ceel is linked by road to two eastern terminus groups that fall on the same causeway and that almost runs the limit of the Vaca Plateau to the Macal River. The western extent of Caracol has yet to be fully defined, although it has been demonstrated that the Ceiba terminus is linked by causeway to the Guatemalan site of La Rejolla. Almost all of these hubs or nodes are associated with sizable plaza areas that would have functioned both as 
markets and for administrative purposes (A. Chase et al. 2015). Some are also associated with large constructed reservoirs.

The outlying public architecture that is part of Caracol's urban environment can be categorized into two distinct forms: preexisting and newly constructed. Preexisting sites were incorporated into the city of Caracol during the Classic period. Based on archaeological data recovered from Cahal Pichik and Hatzcap Ceel by Thompson (1931), it is likely that these Late Preclassic centers were among the first sites joined by roads to the Caracol epicenter. It would appear that the $12-\mathrm{m}$ wide causeway connecting the Caracol epicenter and Cahal Pichik was built outward from each of these areas at the same time; from the awkward angles of the causeway joining, it appears that the surveyors made a mistake that had to be corrected to link the road together (Fig. 6). Site plans and archaeological data from both Retiro and Ceiba indicate that market areas were constructed at the juncture of causeways and the main plazas of these preexisting sites when they were incorporated into metropolitan Caracol. Public plazas in an inner ring (Puchituk, Conchita, and Ramonal) were connected by causeways at a distance of 3 to $3.5 \mathrm{~km}$ from the Caracol epicenter. These public spaces were newly constructed at the very beginning of the Late Classic period for economic and administrative purposes (A. Chase and D. Chase 2001a).

Between 1986 and 2003, transit mapping at Caracol recorded structures, residential groups, and approximately 100 residential reservoirs in a $23-\mathrm{km}^{2}$ area of
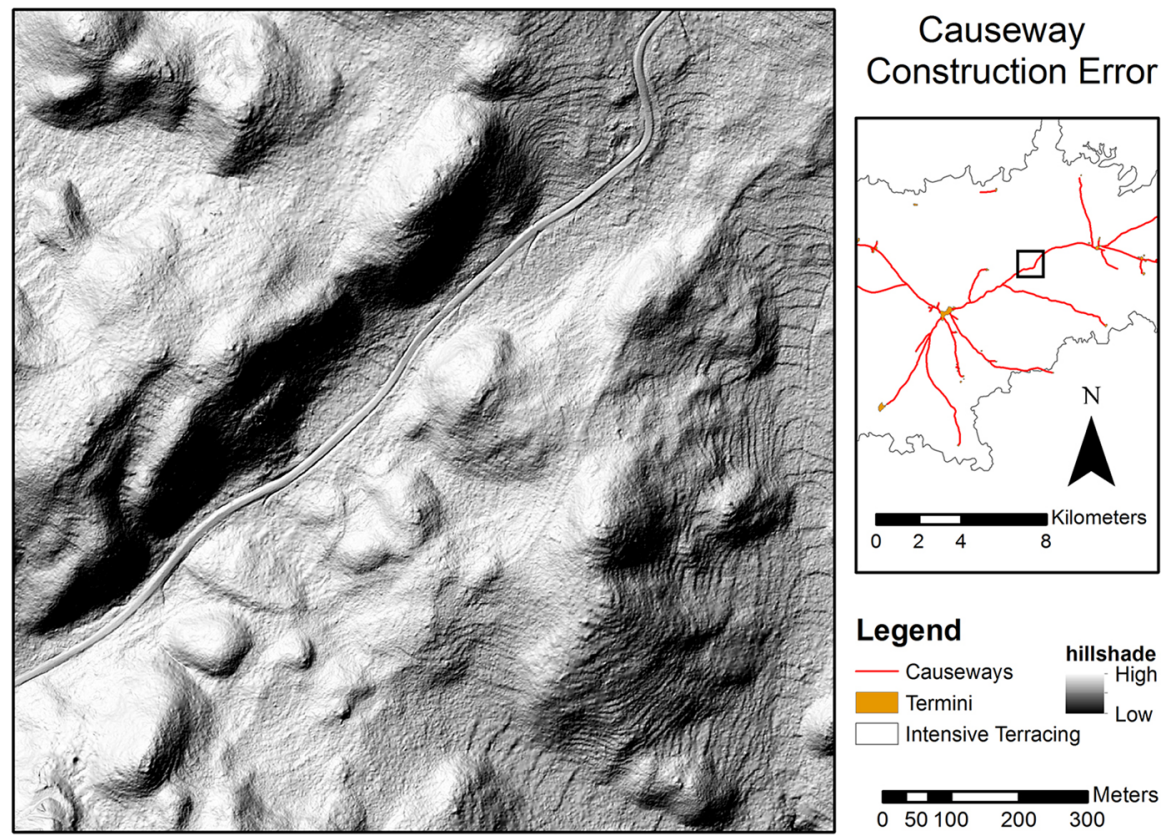

Fig. 6 The misalignment of the Caracol to Cahal Pichik Causeway, indicating two different construction efforts; also visible in the LiDAR image are some of Caracol's ubiquitous terraces and a modern road paralleling the ancient causeway (image by Adrian S. Z. Chase for the Caracol Archaeological Project) 
the site (Fig. 7). The mapping used a labor-intensive grid pattern (A. Chase 1988). Approximately $4 \mathrm{~km}^{2}$ of terracing also was recorded (A. Chase and D. Chase 1998a). In general, however, because the terraces were ubiquitous on the overgrown karst landscape, further documentation was needed. When LiDAR data were first acquired for Caracol in 2009 (A. Chase et al. 2011, 2012; D. Chase et al. 2011), it was finally possible to demonstrate effectively how intensively the landscape had been modified by the ancient Maya; terracing had become more dense in areas that had long-occupied, substantial residential settlement, and newer agricultural terracing extended farther and farther outward as Caracol developed (D. Chase and A. Chase 2014b).

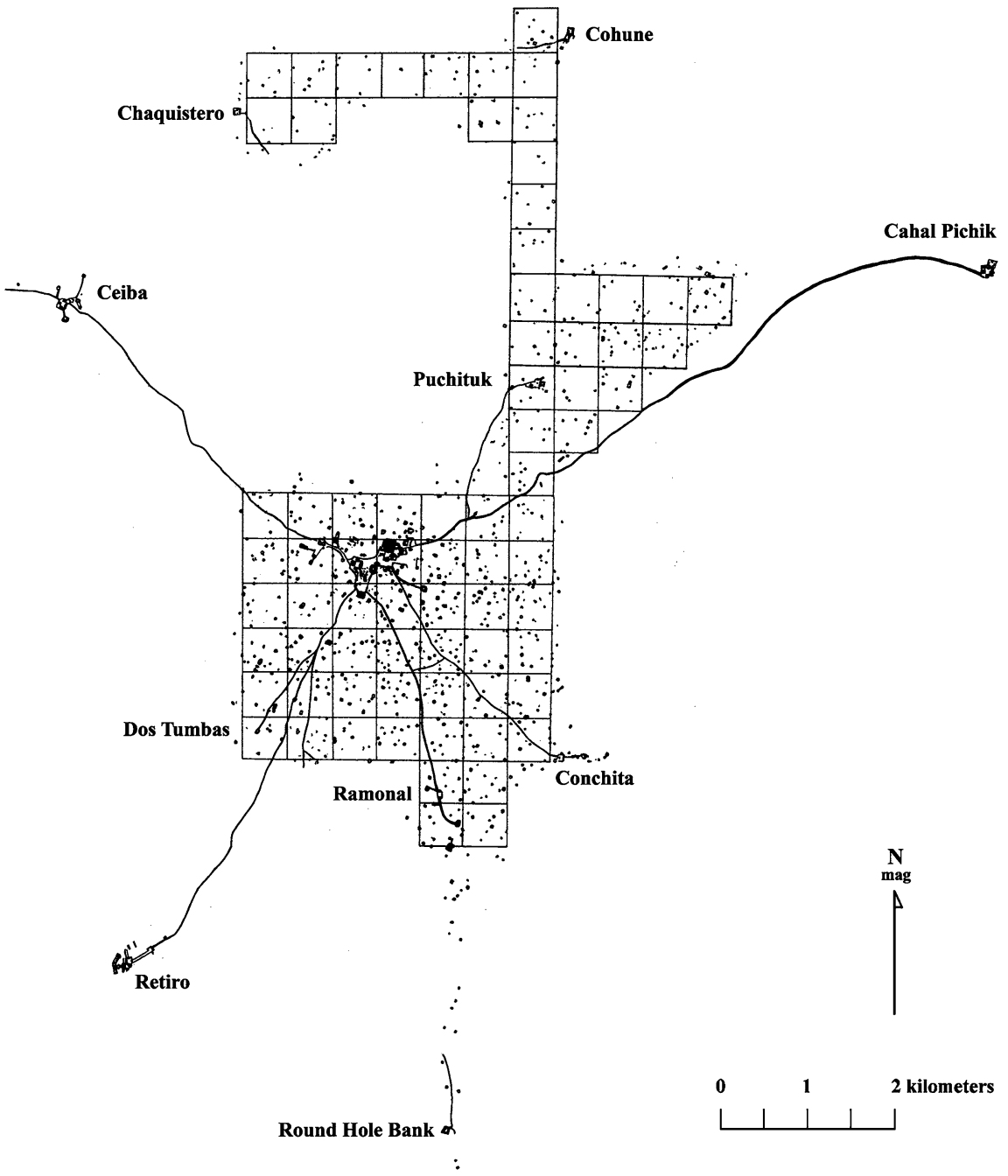

Fig. 7 The Caracol map showing $23 \mathrm{~km}^{2}$ of mapped settlement; each dot is a residential group 
Many CAP field seasons have focused exclusively on settlement investigations (both excavation and survey). Causeways running through settlements to outlying terminus groups were initially discovered through survey. Given the size of the site, these features proved instrumental by providing avenues for accessing distant settlements and a mechanism for sampling and mapping Caracol. The causeways to the Conchita Terminus and to the Ramonal Terminus were among the first followed from the epicenter into the outlying site core. These causeways defined a triangular, pie-sliced region of the site that extended out from the epicenter for $3.5 \mathrm{~km}$. A settlement program was designed to map and archaeologically excavate a sample of residential groups in this sector to determine whether settlement was correlated with the causeways (Jaeger 1987; Jaeger Liepins 1994) and what effect successful warfare had on a Maya site through construction and wealth indicators recovered in the archaeological record (A. Chase and D. Chase 1987, 1989). Excavation and mapping in this area were undertaken from 1987 through 1989, with excavations in 43 residential groups.

These excavations demonstrated that, while some residential groups were occupied earlier, all tested groups were occupied in the Late Classic period. Significantly, a large number of interments and caches were recovered in the residential groups as well as workshops associated with conch shells (Cobos 1994) and lithic drills (Pope 1994). The recovery of many formally constructed tombs in the residential groups showed that these features were not restricted to the elite; this finding set the stage for later investigations into prosperity and shared identity at the site. Most of the deposits were associated with ceramic material that could be dated (A. Chase 1994), resulting in the correlation of successful warfare stated in the hieroglyphic record with the rise of general prosperity at the site as represented by the widespread distribution in residential groups of eastern shrines, formal tombs, specially made ceramic cache vessels, polychrome ceramics, carved shell, and filed and/or inlaid dentition. The excavations undertaken in this initial settlement program also served to test the occupational histories of the investigated residential groups and indicated that there was a significant population increase at Caracol at the beginning of the Late Classic period (A. Chase and D. Chase 1989). Testing on the Conchita and Ramonal causeways also indicated that both had been plastered and, in some cases, were built over preexisting agricultural terraces.

A second settlement program-funded by the National Science Foundation between 1994 and 1996-focused on the northeast part of the site beyond the C Group and Northeast Acropolis. There a pie-slice sector was systematically mapped for settlement; $2 \mathrm{~km}^{2}$ of agricultural terraces were recorded, and 28 residential groups were archaeologically sampled. Again, the preponderance of residential groups dated to the Late Classic period, although early and later remains also were encountered. The results of this second settlement program supported previous findings; there was growth in population, general prosperity, and a shared identity following successful warfare. This second program also showcased potential differences among Caracol's site sectors in terms of residential status and available trade items (see D. Chase and A. Chase 2014a, p. 246).

Eight other seasons have focused on outlying residential groups: 9 groups in the northwest portion of the site, 11 groups in the southern portion, and 7 groups in the 
site center. Additionally, 18 groups in the immediate vicinity of the Machete Terminus were tested to examine the concept of neighborhood (after Smith 2010b; Smith and Novic 2012). These investigations highlighted variation in the groups relating to size, status, and length of occupation. Several cases of urban renewal also were encountered in which the Maya attempted to remove all earlier occupation from the landscape before new building efforts began. The wealth of items recovered in the investigations of the Caracol residential groups includes all manner of other artifactual materials (see field reports at www.caracol.org). Our examination of similarity and variation in proximate residential groups demonstrated not only that coeval residential groups of different statuses existed side-by-side, similar to other "walking cities" (Rothchild 2006; G. Storey 2006), but that even lowerstatus residential groups had access to prestige items. Other findings from these investigations were unusual. One cache, recovered in a plaza in front of a small residential building (Structure $\mathrm{C} 21$ ), yielded 3 eccentric cherts (the first found at Caracol after 24 seasons of excavation), 8 obsidian eccentrics, brain coral, 3 stingray spines, 52 stingray vertebrae, 138 slate mirror pieces, 747 jadeite chips, and 4751 Spondylus chips. When combined with epicentral data, the settlement work recovered substantial archaeological materials that provided the ability to fine tune the chronological dating throughout the site through the combination of hieroglyphic dates, radiocarbon dates, and ceramic seriation (A. Chase 1994; A. Chase and D. Chase 2013b). These data also could be used to answer questions about site development, integration, and abandonment.

In addition to the annual CAP investigations, there have been two larger-scale consolidation efforts at Caracol that permitted the excavation of room interiors and complete plazas. The first was sponsored by the U.S. Agency for International Development and the Government of Belize and run as a part of CAP from 1989 through 1993; it funded the excavation and subsequent consolidation of buildings throughout the site epicenter, meeting a government goal of attracting tourists to the site. The second effort was sponsored fully by the Government of Belize and directed by J. Awe, supported by a loan from the International Development Bank. Linked to the paving of the last 12 miles of road into the site so that tourists could access the site during the rainy season, the project ran from 2000 through 2003 and led to the consolidation of more buildings and many supporting platforms throughout the site epicenter. One focus of this effort was augmenting the earlier consolidation of the summit and front face of Caana, Caracol's largest architectural complex (Fig. 8).

\section{History of Ancient Maya Occupation at Caracol}

\section{Preclassic Period and the Initial Settlement of Caracol (600 BC AD 250)}

Caracol was first occupied in the Middle Preclassic period at about $600 \mathrm{BC}$; the presence of settlement distant from natural water sources indicates that the ancient Maya in the Caracol area were already capable of constructing water storage features like reservoirs. The earliest remains have thus far been found in outlying 


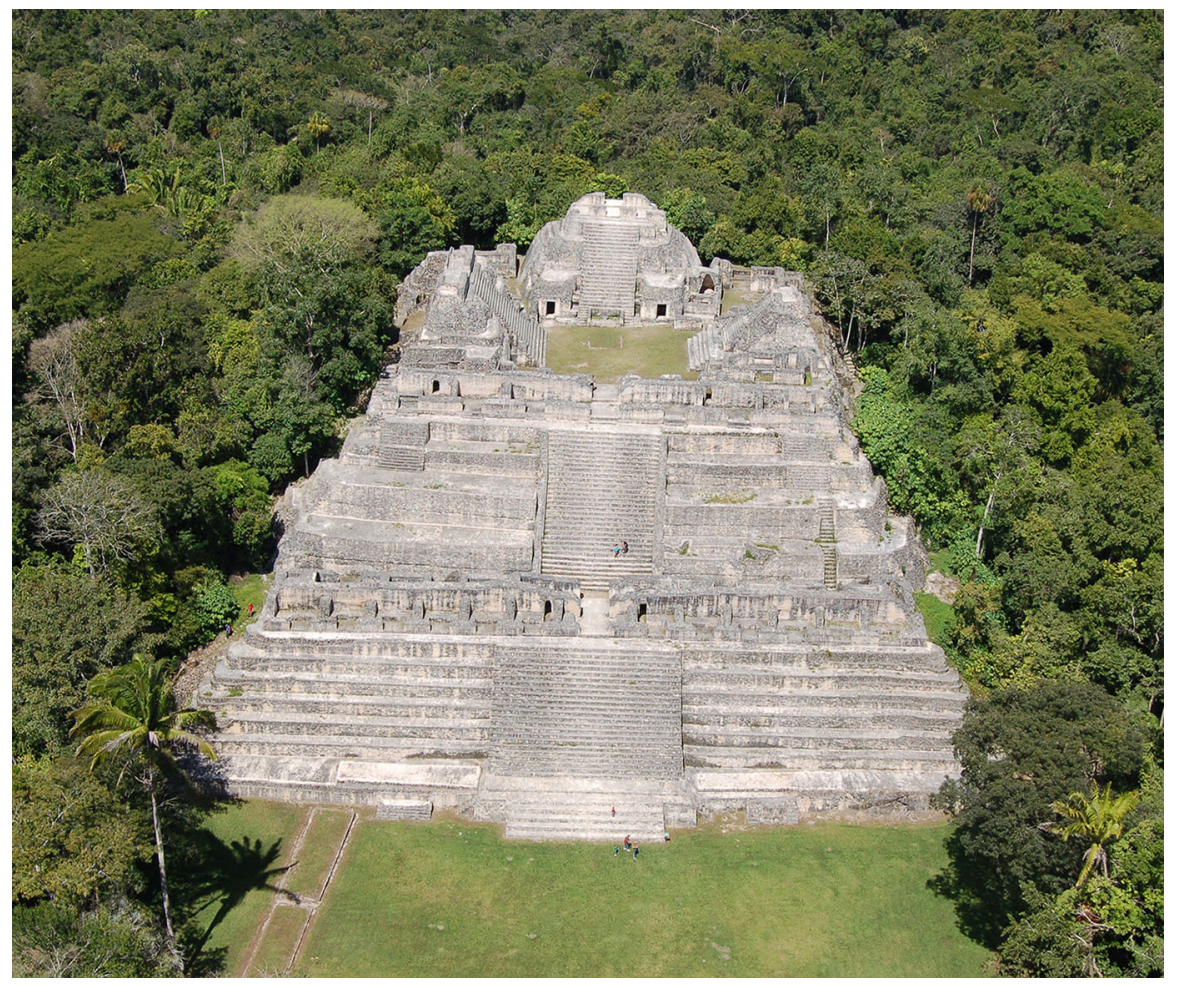

Fig. 8 Caana, looking north, after stabilization was completed by the Belize Government

residential settlement (A. Chase and D. Chase 2006, p. 43), although buried occupation dating to the Late Preclassic, perhaps as early as $300 \mathrm{BC}$, has been found beneath many of the epicentral platforms. Because this settlement is deeply buried below later monumental architecture, this earliest occupation has not been as fully excavated or studied as later time periods. Among the early burials recovered at Caracol is one in the bottom of a collapsed chultun in the Northwest Group, dating to approximately $200 \mathrm{BC}$; it contained two individuals. Artifacts indicate both a knowledge of standard status markers and participation in the wider sphere of Maya ritual practice. Associated materials include a jadeite pendant, a Spondylus shell, and a stingray spine as well as four ceramic vessels, including a spouted jar that was likely imported from the Belize Valley and demonstrates early, close connections with this area.

Caracol's location —off the beaten track in the 21 st century-was well situated in the ancient Maya world. It was proximate to key local resources that were exported throughout the Maya Lowlands, specifically hard stone for manos and metates and slate suitable for carving monuments and capstones (e.g., Graham 1987), something that was clearly exploited for trade (A. Chase et al. 2014a). In addition, the site was conveniently located relative to trade routes that extended from the Belize River to the Usumacinta River and along the western edge of the Maya Mountains running 
into southern Belize (A. Chase and D. Chase 2012, 2017) —even live fish could be imported into the site (Cunningham-Smith et al. 2014). That the Late Preclassic period population at Caracol was in communication with lowland Maya centers elsewhere is indicated by similarities in ceramics, monumental constructions, and ritual cache practices. Caana itself had reached a height of $38 \mathrm{~m}$ in the Late Preclassic period (A. Chase and D. Chase 2006, p. 47), and Late Preclassic occupation has been identified on both sides of Caana. Some of the more interesting finds dating to this time period are found in the A Group, specifically associated with Structure A6, the Temple of the Wooden Lintel, which formed the central building for an eastern E-Group platform (or horizon-based astronomical construction) that was ritually dedicated in $\mathrm{AD} 41$, presumably timed for the shift to baktun 8.0.0.0.0; the series of caches set in the core of this building (A. Chase and D. Chase 1995) served to center the site (D. Chase and A. Chase 1998), and the contents of the caches predate the elaborate caches found at Tikal by almost 300 years (A. Chase and D. Chase 2006, p. 53). Krejci and Culbert (1995, p. 113) note that most Preclassic period caches at Tikal contain very little until after AD 325.

Many of the earliest cache offerings from Caracol show directionality and layering that mirror Maya worldview (D. Chase 1988; D. Chase and A. Chase 1998; Mathews and Garber 2004); the most explicit examples are from the Late Preclassic caches (S.D. C8B-1 and S.D. C8B-3) within Structure A6, dating to circa AD 41. One of these caches contained a mirror, reflecting the heavens, set atop green-blue malachite chips representing the color of water and the entrance to the underworld; color-coded shells were set to the four directions with a single earflare in the center, representing the quincunx of Maya directionality and the surface of the earth (see D. Chase 1988; D. Chase and A. Chase 1998). They were surrounded by a set of shells carved in human form (called Charlie Chaplins) (e.g., Lomitola 2012; Moholy-Nagy 1985) and other small shell and jadeite figures; above all of this was a beehive representing flight and the sky of the upperworld. Another cache in a sealed geode contained $664.7 \mathrm{~g}$ of liquid mercury upon which had been placed malachite chips; above the chips were paired Spondylus shells containing a carved jadeite mask, then a single earflare assemblage (representing the axis mundi) and more malachite chips (A. Chase and D. Chase 1995, p. 96). The complexity of the contents, directionality, and layering in these caches not only demonstrates Caracol's long-distance connections and precociousness but also that the site's rulers were ritual innovators.

The Maya significantly transformed Caracol at several points in its history after its initial settlement in $600 \mathrm{BC}$. The ritual building complex in the A Group, although originally constructed prior to $300 \mathrm{BC}$, was apparently rebuilt and ritually reestablished to coincide with the beginning of the 8th baktun in $\mathrm{AD} 41$, providing an early indicator of Caracol's focus on marking the passage of time. And while there were members of the ruling elite at the site well before this time, the Caracol dynasty was not founded until the 4th century AD (Table 1). 
Table 1 Reconstruction of Caracol's history based on dated events in the hieroglyphic texts and the archaeological record

\begin{tabular}{|c|c|c|}
\hline Maya time periods & Date & Caracol events \\
\hline \multirow[t]{3}{*}{$\begin{array}{l}\text { Preclassic } 1200 \text { BC-AD } 250 \text { Small } \\
\text { sedentary villages followed by } \\
\text { development of monumental architecture, } \\
\text { palaces, and larger center }\end{array}$} & ca. $600 \mathrm{BC}$ & $\begin{array}{l}\text { Earliest known settlement at Caracol. } \\
\text { Occupation present in the settlement } \\
\text { area and buried below monumental } \\
\text { architecture }\end{array}$ \\
\hline & $\begin{array}{l}\text { ca. } \mathrm{AD} 41 \\
\text { celebration of } \\
\text { 8th Baktun }\end{array}$ & $\begin{array}{l}\text { Structure A6-1st, "Temple of the } \\
\text { Wooden Lintel," constructed and } \\
\text { consecrated with caches; full Maya } \\
\text { ritual complex present at Caracol }\end{array}$ \\
\hline & ca. $\mathrm{AD} 150$ & $\begin{array}{l}\text { Elaborate burial placed in NE } \\
\text { Acropolis Structure B34 locus }\end{array}$ \\
\hline \multirow[t]{19}{*}{$\begin{array}{l}\text { Classic AD } 250-900 \text { "Peak" of Maya } \\
\text { civilization; pyramids, tombs, inscriptions, } \\
\text { widespread trade; by AD } 800 \text { Maya } \\
\text { "collapse" underway }\end{array}$} & ca. $\mathrm{AD} 331$ & $\begin{array}{l}\text { Caracol royal dynasty "officially } \\
\text { founded (based on text from the B } \\
\text { Plaza ballcourt). Establishment of } \\
\text { the dynasty likely coincided with } \\
\text { formal incorporation of outlying } \\
\text { causeway termini into Caracol. } \\
\text { Teotihuacan related interment in NE } \\
\text { acropolis. Substantial ritual activity }\end{array}$ \\
\hline & ca. $\mathrm{AD} 480$ & $\begin{array}{l}\text { Unknown ruler's tomb placed in } \\
\text { Structure D16 }\end{array}$ \\
\hline & AD 531 & Accession of Lord Water's predecessor \\
\hline & AD 537 & $\begin{array}{l}\text { Use of initial tomb in Structure B20- } \\
\text { 3rd }\end{array}$ \\
\hline & AD 553 & $\begin{array}{l}\text { Accession of Caracol ruler Lord Water } \\
\text { as Ahau }\end{array}$ \\
\hline & AD 556 & "Axe Event" against Caracol by Tikal \\
\hline & AD 562 & "Star-War" defeat of Tikal by Caracol \\
\hline & AD 566 & Birth of Batz Ek \\
\hline & AD 575 & Birth of Smoke Ahau \\
\hline & AD 577 & Second tomb in Structure B20 used \\
\hline & AD 577 or 582 & $\begin{array}{l}\text { Lower tomb in Structure A34 } \\
\text { consecrated. Tomb placed in Central } \\
\text { Acropolis plaza }\end{array}$ \\
\hline & AD 588 & Birth of Caracol ruler K' an II \\
\hline & AD 599 & $\begin{array}{l}\text { Accession of Caracol Lord Smoke } \\
\text { Ahau to a ritual office }\end{array}$ \\
\hline & AD 614 & Tomb in Structure L3 covered \\
\hline & AD 618 & Accession of K'an II as Ahau \\
\hline & AD 626-636 & $\begin{array}{l}\text { Naranjo wars; major expansion of } \\
\text { Caracol followed }\end{array}$ \\
\hline & AD 634 & $\begin{array}{l}\text { Woman's tomb in Structure B19-2nd } \\
\text { closed }\end{array}$ \\
\hline & AD 658 & $\begin{array}{l}\text { Death of K'an II; accession of ruler } \\
\text { Smoke Skull }\end{array}$ \\
\hline & AD 680 & Naranjo's war of independence \\
\hline
\end{tabular}


Table 1 continued

\begin{tabular}{|c|c|c|}
\hline $\begin{array}{l}\text { Maya time } \\
\text { periods }\end{array}$ & Date & Caracol events \\
\hline & AD 696 & Tomb in Structure A3-1st covered \\
\hline & $\mathrm{AD} 702$ & Capture of Ixkun lord noted on Stela 21 \\
\hline & $\mathrm{AD} 798$ & Accession of Caracol ruler Hok K'awiil \\
\hline & $\mathrm{AD} 800$ & $\begin{array}{l}\text { Capture of } 2 \text { prisoners, including Ucanal lord, by Caracol Ruler Hok K'awiil } \\
\text { or his underlings (Altar 23) }\end{array}$ \\
\hline & $\mathrm{AD} 810$ & Bound prisoners depicted on Altar from Plaza of the Two Stelae \\
\hline & $\begin{array}{l}\mathrm{AD} \\
800-884\end{array}$ & Scenes of alliance on various Caracol Monuments \\
\hline & $\mathrm{AD} 884$ & Last recorded monument date \\
\hline & AD 900 & $\begin{array}{l}\text { Burning in Caracol epicentral buildings; last use of Structure A6; majority } \\
\text { of Caracol epicenter abandoned }\end{array}$ \\
\hline & & No known occupation of Caracol \\
\hline
\end{tabular}

\section{Protoclassic and Early Classic Period Caracol: The Beginnings of Dynasty (AD 250-550)}

While the existence of a pan-Maya Protoclassic phenomenon (representing either a time period or a precocious social development) is still in dispute (see Brady et al. 1998), the archaeological record of Caracol contains an identifiable segment of materials that is distinct from those of the Late Preclassic and those of the late Early Classic (one key component of which is the presence of cylinder tripods). Protoclassic period occupation at Caracol could just as well be called "early" Early Classic; its ceramics exhibit stylistically earlier design elements. The known contexts from the site, however, indicate that there is a conjunction of Late Preclassic and Protoclassic ceramic modes with earlier slips being used with later vessels forms. These materials are widespread at Caracol and are known from burials, fill, and trash dumps; when viewed together, they help to better contextualize this poorly understood time period elsewhere in the Maya Lowlands (see Callaghan 2013 for Holmul; Smith 1955 on Matzanel at Uaxactun). Within the Northeast Acropolis was a "Protoclassic" burial of a woman interred in costume as the Maya moon goddess (Rich 2003). Dated to approximately AD 150, she was accompanied by two figurines, 32 ceramic vessels, and a mantle fringed with dog teeth onto which were sewn over 7000 jadeite and shell beads (A. Chase and D. Chase 2005, p. 22). The white-slipped bowls with this interment are similar to Kaminaljuyu whiteware vessels from the Guatemalan highlands (Rice 1978; Weatherington 1978); ring bases are present on other bowls in this interment that also exhibit three colors (polychrome decoration). This burial indicates that Caracol had long-distance trade relationships with the highlands of Guatemala and that social stratification was already present at the site by this early date.

Early Classic period constructions are present in all of the major loci of the Caracol epicenter and throughout the settlement area. Conservative estimates are that more than 
30,000 people lived at the site prior to the beginning of the Late Classic period in AD 550 (D. Chase and A. Chase 2014b, p. 146). Early Classic period Caracol is likewise well known from ritual deposits, particularly from epicentral caches and tombs. The elaborate contents and layering of Early Classic caches both in the epicenter and its residential groups indicate the importance of temporal and cosmological ritual to the Caracol population. These caches contain carved shell, including Charlie Chaplin figures, as well as ritual items imported from both the Pacific and Atlantic Coasts. As noted above, a burial in the central plaza of the Northeast Acropolis indicates that Caracol had a relationship with Teotihuacan, Mexico (the early primate urban center in the Valley of Mexico); based on the form of the burial, its associated artifacts, and its plaza placement, it is likely that a Teotihuacan individual married into a Caracol elite family, enhancing a trade relationship between the two sites. From historic texts, we know that the date that later Caracol rulers mark as the beginning of their formal dynasty-AD 331 — corresponds with the dating of the Teotihuacan interment in the Northeast Acropolis (A. Chase and D. Chase 2011). However, rather than seeing the instillation of a foreigner king (e.g., Price et al. 2010), all indications are that the development at Caracol was a process of internal lowland Maya elaboration rather than the result of direct external influence and pressure from other cultures like Teotihuacan (e.g., Braswell 2003). By the late Early Classic period, causeways had already been built to join Caracol with what had earlier been two independent neighboring sites within the Vaca Plateau-Hatzcap Ceel and Cahal Pichik. The beginning of the Caracol dynasty likely coincided with a coagulation of these nearest-neighbor sites into a single polity under the control of Caracol proper, although the full incorporation of these centers into the city of Caracol may not have occurred until the Late Classic period.

\section{Hieroglyphs, Rulers, and Dynasty}

Much of Caracol's appeal to archaeologists and the public lies in the carved monuments and hieroglyphic record that provide insight into the site's history (Beetz 1980; Beetz and Satterthwaite 1981; A. Chase 1991; A. Chase and D. Chase 1987, 2015b; A. Chase et al. 1991, 2008a; D. Chase and A. Chase 2008; Grube 1994; Helmke et al. 2006; Houston 1987, 1991; Martin 2005; Martin and Grube 2000, 2008; Savage 2007). Although uneven, this historic record covers over 450 years. The 55 carved stone monuments known from the site constitute the largest hieroglyphic corpus in Belize. Besides the stone monuments (26 carved stelae and 29 carved altars), hieroglyphic writing occurs on a variety of other mediums at Caracol that include modeled stucco on buildings, painted tomb capstones and wall texts, painted and incised ceramic vessels, and carved bone. The earliest dated texts at the site come from the A Group and include a purely hieroglyphic fragment of an 8th cycle monument buried at the summit of Structure A2 and Stela 20 dating to 8.18.4.4.14 or AD 400 at the base of the eastern platform (Fig. 9). A retrospective text from a B Group ballcourt marker (dating to the Terminal Classic period) records the founding of the Caracol dynastic count in AD 331. The latest known text at Caracol, from the summit of Structure A13, is an altar that dates to $\mathrm{AD} 884$ and that portrays the interaction between two individuals, 
Fig. 9 Caracol Stela 20, dating to $\mathrm{AD} 400$; the monument is $0.75 \mathrm{~m}$ wide and approximately $3.20 \mathrm{~m}$ tall; the fragments of the monument appear to record a date of 8.18.4.4.12, but it is likely that the actual date was 8.18.4.4.14 as this agrees with the coefficient of the Tz'olkin and means that two dots have spalled off of the day sign

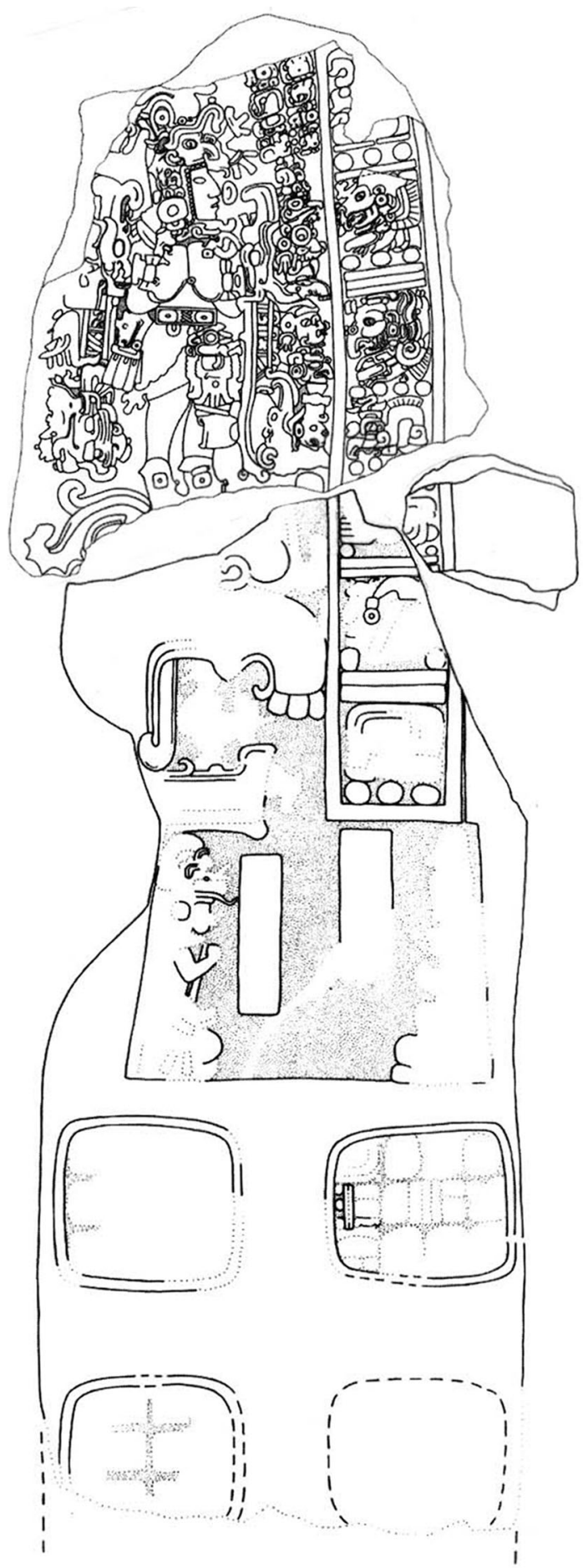




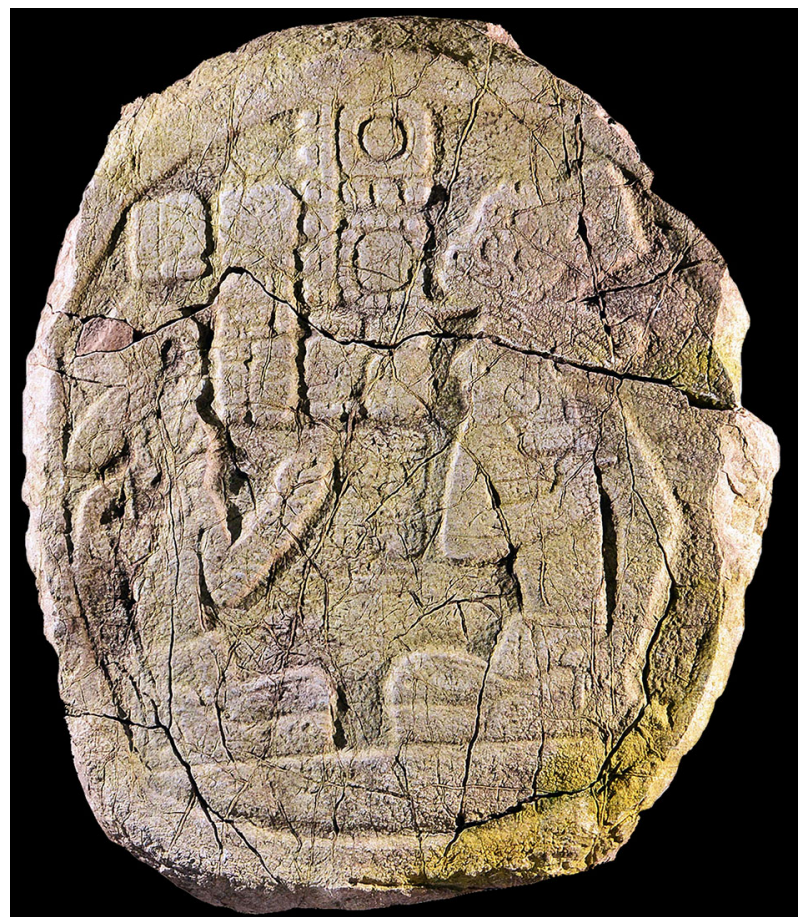

Fig. 10 Caracol Altar 26, dating to AD 884; the monument is $0.73 \mathrm{~m}$ tall and $0.63 \mathrm{~m}$ wide

potentially indicating an alliance with a foreign individual at this late date (Fig. 10; see also Chase and Chase 2015b).

A list of site rulers and key individuals and events can be derived from the stone monuments and the stucco façade texts (see Table 1). Caracol is associated with both an emblem glyph ("kan-cross" main sign) and a place name or toponym (the "3-stone place"). The emblem glyph is of variant style, as there is often no "ahau" (or "ajaw") prefix (read as "sun lord" or "ruler") (Houston 1986); the lack of this affix is consistent with what appears to be a more collective governing strategy at the site. The toponym is associated with a place of creation (e.g., Stuart 1998); it also occurs in a text at Copan, Honduras, and has been linked back to Caracol as potential support for a dynastic connection between the sites (Stuart 2007; Stuart and Houston 1994:23; see also Price et al. 2010). The sequence of rulers is not complete and, interestingly, does not currently correlate with the remains of any member of the royal family buried in dated tombs at the site (A. Chase and D. Chase 1996c; D. Chase and A. Chase 2008). Significantly, the elite burials in Caracol's major buildings that contain death dates or tomb closing dates all occur during time periods when the site's stone monuments record Caracol rulers as being alive, suggesting that the general tendency to automatically correlate elite tombs with rulers (e.g., Jones and Satterthwaite 1982 for Tikal; Valdes and Fahsen 1995 for Uaxactun) may be unwise. Perhaps the best-known Caracol rulers include Yajaw 
Te' K'inich II (Lord Water), who defeated Tikal in AD 562, and his son, K' an II, who ruled Caracol during the Naranjo wars from AD 626 to AD 636. Following their combined periods of rule, Caracol saw its greatest population boom, the crystallization of Caracol's shared identity and its system of symbolic egalitarianism, and the full implementation of the site's regional market system.

The earliest ruler at Caracol is retrospectively referred to as Te' $\mathrm{K}$ ' ab Chaak ("Branch Rain God"; Martin and Grube 2008) and is associated with a specific date in AD 331 that likely marks his accession. The next known monument (Stela 20) dates to $\mathrm{AD} \mathrm{400,} \mathrm{as} \mathrm{mentioned} \mathrm{above;} \mathrm{although} \mathrm{the} \mathrm{text} \mathrm{is} \mathrm{too} \mathrm{eroded} \mathrm{to} \mathrm{derive}$ detailed historical information, it contains a boxed initial series date similar to monuments from the Guatemalan highlands (e.g., Sharer and Sedat 1987), again reinforcing Caracol's early ties to the southern Maya area. A cache of buried stelae in front of Structure A4 (Beetz and Satterthwaite 1981) provides the bulk of the known information about Caracol's Early Classic rulers and, through names and emblem glyphs, hints at their relationships with Tikal and Copan (Grube 1994). Yajaw Te' K'inich II acceded in AD 553 and governed for at least 40 years; this ruler gained Caracol's independence from Tikal in AD 562 as a result of a successful "star-war" (so named after the glyphic elements and their association with warfare) recorded retrospectively on Caracol Altar 21 by his son K'an II. The death of Yajaw Te' K'inich I caused dynastic issues that are reflected in Caracol's textual record. On Caracol Stela 5, an individual named Knot Ajaw is recorded as acceding to a ritual office in AD 599 and carrying out some ceremonies for the deceased Yajaw Te' K'inich II. Yet, Caracol Stela 1 links Yajaw Te' K'inich II to his son, K'an II (born in AD 588), and Stela 3 provides a fuller history of K'an II and his protector, B' atz Ek (possibly a maternal uncle), who likely served as regent until his accession in AD 618. In K'an II's monuments, Knot Ajaw is never mentioned, although clearly all of these individuals coexisted.

K' an II carried out a series of three battles against Naranjo in AD 626 and 628 and then a "star-war" in AD 631; these events are recorded on several texts at Caracol and on monuments at both sites. Following the AD 631 star-war, K' an II likely made Naranjo a second capital and from this vantage point was better able to control Tikal territorially based on military marching distance (A. Chase and D. Chase 1998b; see also Schele and Freidel and 1990). K' an II died in AD 658, after having installed his successor K'ak' Ujol K'inich (literally "Fire is the Skull of the Sun God," shortened to "Smoke Skull"; Grube 1994), who also is named in texts at La Rejolla, Guatemala (a causeway terminus and part of metropolitan Caracol). According to a stucco text from Caana, Naranjo regained its independence from Caracol in $\mathrm{AD}$ 680, forcing a 168-day exodus of the current ruler at the site (Fig. 11). After this event, however, carved stone hieroglyph texts focused on K'an II, the Caracol ruler who carried out the earlier star-war at Naranjo, were reassembled out of order at Naranjo and also were placed at Ucanal, Guatemala, and Xunantunich, Belize (Helmke and Awe 2016a, b). Yet Caracol itself continued. The limited textual material from the end of the Late Classic suggests that Structure A3 was renovated in AD 696 and that the range building half way up the south face of Caana was built in the mid-700s. For the most part, however, records of strong dynastic rulers during the Late Classic are lacking, and there was a de-emphasis in 


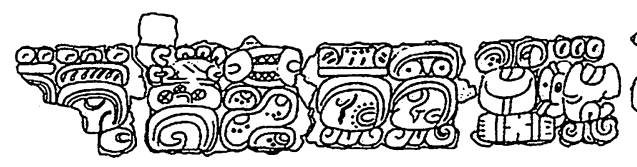
9.9.13.4.4
A.D. 626

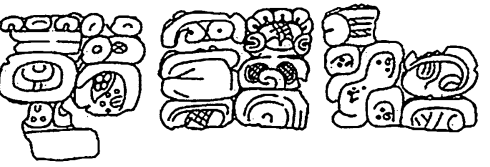

9.9.13.8.4 destroyed ko-3-cauac by him A.D. 626

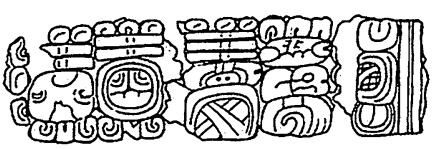

9.9.14.3.5

A.D. 627 destroyed

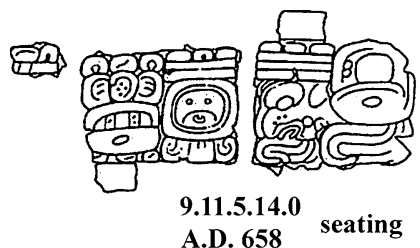

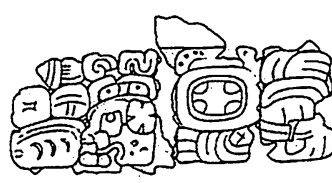

ahau Smoke Skull Caracol
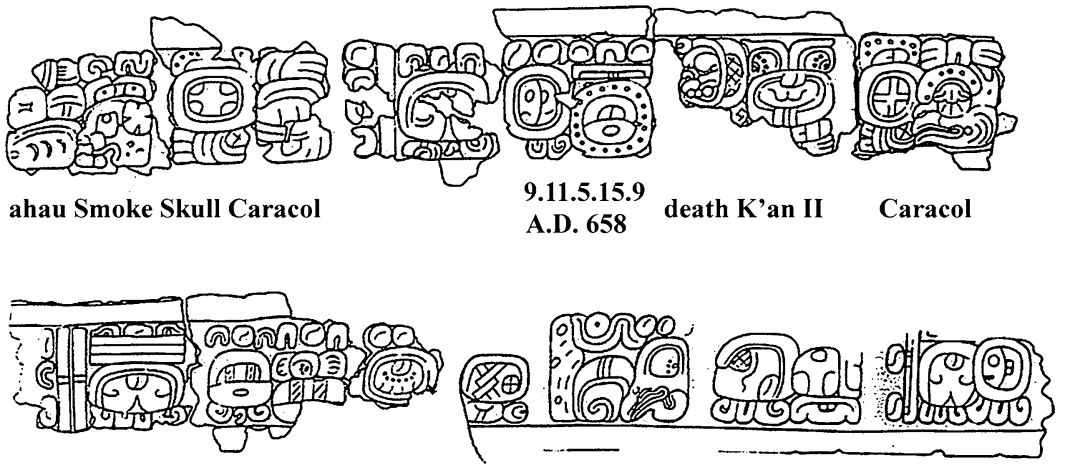

9.12.7.14.1

A.D. 680

9.11.5.15.9

A.D. 658
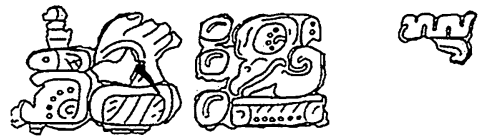

star-war 3-stone place by Naranjo

9.12.8.4.9
A.D. 680

Fig. 11 Stucco text from cornice of building buried beneath Structure B16 (glyph height $20 \mathrm{~cm}$ )

carving dynastic monuments until just before AD 800, even though the site reached its greatest population levels and achieved its greatest integration during this time.

Carved monuments were again prominent just before AD 800. The Terminal Classic Caracol ruler about whom we know the most is K'inich Joy K'awiil. His accession in AD 798 is recorded on a series of ballcourt markers associated with the B Plaza, where he is recorded as being the 27th ruler of the site (A. Chase et al. 1991; Helmke et al. 2006). There are archaeological and epigraphic indications of significant differences between the earlier and later rulership of the site, likely indicative of a dynastic break. Late Classic tombs on Caana were desecrated, and the earliest known Terminal Classic stela (Stela 18 dating to AD 810) shows a rearing serpent over a bound prisoner, suggesting the use of mythology and cosmology to reestablish dynastic rule. The Terminal Classic rulers may have 
changed on a fairly regular basis, perhaps in association with the passing of each katun, which has been taken to indicate that a "batabil" form of organizationwhere leadership was held for a set period of time by a selected individual in a form of collaboration governance not focused on a single ruling dynasty (and known from the northern lowlands; Restall 1997; Quezada 1993, 2014)_may have been instituted at Caracol (A. Chase et al. 2009, p. 181).

Many of Caracol's Terminal Classic monuments also portray two individuals of roughly equal stature, often with gestures of friendship or submission that suggest they were interacting with each other either in shared rituals or political alliances (A. Chase and D. Chase 2015b; A. Chase et al. 1991). Given Caracol's proclivity for the ritualization of temporal cycles (A. Chase and D. Chase 2013a), it may be that some of the paired individuals on the site's latest monuments literally were passing temporal authority from one to another at auspicious moments. Similar paired iconography also is known from both Sacul (Mayer 1990) and Ixkun (Laporte and Torres 1987), sites closely allied with Caracol during this era. Caracol, with its alliances and its relative longevity, provides a very different view of the Maya collapse (e.g., D. Chase and A. Chase 2006) than has been gained from the Usumacinta area, where a relatively early collapse is indicated in the archaeological record (Demarest 2006, 2013; Foias and Bishop 1997; Inomata 2003).

\section{Late Classic Period Caracol and Urban Expansion}

Toward the end of the Early Classic period and beginning of the Late Classic period, Caracol rulers were clearly engaged with other Maya centers. Epigraphers have identified Caracol as the likely origin point for the first ruler of Copan; stable isotope information from Copan's burials supports such an interpretation (Nichols 2016; Price et al. 2010). Not only did Caracol apparently solidify its position to its south, a point possibly emphasized in the textual materials at Caracol with eroded references to Copan (Grube 1990), but the site also embarked on a series of wars with neighboring polities to the north. Altar 21 from the A Group ballcourt notes the defeat of Tikal in AD 562 (A. Chase 1991; A. Chase and D. Chase 1987, 1989, 1998b; Houston 1991). A series of monuments and stucco texts describe a history of wars with neighboring Naranjo in the early 7th century (D. Chase and A. Chase 2002, 2003a; Schele and Freidel 1990); it was at this point early in the Late Classic period that Caracol's population boomed. The city itself expanded beyond the original incorporation of Cahal Pichik and Hatzcap Ceel with the addition of new, purposefully constructed causeway terminus groups at Puchituk, Conchita, and Ramonal. The formerly independent centers of Retiro and Ceiba also became directly linked to Caracol and its market system (A. Chase et al. 2015; D. Chase and A. Chase 2014a). The successes of Caracol in war, combined with some forward-looking management strategies, likely led to in-migration from elsewhere in the lowlands. By AD 700, additional causeways that eased transportation and communication into the surrounding countryside had been constructed, additional agricultural terraces had been built, and over $200 \mathrm{~km}^{2}$ of area was incorporated within a single continuously settled urban space that supported more than 100,000 people (A. Chase et al. 2014a). In spite of some resistance to the 
idea that the Maya would have maintained an administrative bureaucracy (e.g., Foias 2013, pp. 123-133), the sheer population mass at Caracol implies the existence of a substantial secondary elite or administrative bureaucracy to manage the necessary resources required by the residents of thousands of household groups (A. Chase and D. Chase 2015a); this bureaucracy operated in palace compounds in the site epicenter and at some of the terminus groups and is implied in hieroglyphic texts on epicentral buildings that refer to individuals who were not dynastic rulers (A. Chase and D. Chase 2001b, p. 123). Intriguingly, although AD 700-800 was the era of Caracol's greatest occupation and prosperity, as indicated above it corresponds to a period with relatively few dynastic texts; the little textual information that exists is not from carved stone monuments but from eroded stucco texts that fell off of Caana's buildings (Grube 1994). This lack of Late Classic stone monuments at Caracol may have been due to their purposeful destruction by the site's Terminal Classic elite (for which we have no direct evidence) or, alternatively, it may represent the replacement of an emphasis on elite dynastic monuments with the concerns of a secondary elite who were more focused on managing the site's huge population. Whatever the case, the Late Classic rulers and administrators of Caracol appear to have concentrated efforts on infrastructure, governance, and planned urban development.

\section{Late Classic Period Infrastructure and Planning}

\section{Roads}

Late Classic period Caracol is characterized by a radial causeway system that joined the settlement and epicenter into a single economic and administrative system (A. Chase and D. Chase 2001a) (Fig. 1). Market plazas were placed at the junctions of preexisting sites and causeway terminus groups (D. Chase and A. Chase 2014a). Newly constructed plaza areas were directly linked to high-status residential groups, implying a control network by secondary elite (A. Chase and D. Chase 2015b); some secondary elite had their own causeways that joined their residential groups directly into the road system. Caracol's causeway system not only eased access to important resources such as ground stone from areas along the Macal River but also fostered communication among the site's populace. It was possible to use these causeways to get to the far edges of urban Caracol and back to the epicenter in a single day, meaning that effective communication could be maintained. The construction and utilization of roads elsewhere has been linked to effective military strategy (Hassig 1991), and Caracol's road system would have permitted a more rapid mobilization of its inhabitants (although movement of a full complement of individuals would still have taken substantial time).

\section{Markets}

Using a combined configurational, distributional, and contextual approach, following Hirth (1998, pp. 453-454, 2009, pp. 89-90), as well as a frame of reference recognizing linkages between past and present economic systems (e.g., Feinman and 
Garraty 2010), we have previously documented Caracol's market economy and market locations (A. Chase and D. Chase 2001a, A. Chase et al. 2015; D. Chase and A. Chase 2014a). Multiple markets existed at Caracol. Generally, they took the form of large plaza areas. Not only were markets located in accessible plazas in epicentral Caracol, but they also were located at the terminus groups that ended the majority of Caracol's causeways (A. Chase and D. Chase 2015b). Significantly, no occupant of Caracol had to travel more than $5 \mathrm{~km}$ to access a market (A. S. Chase 2016a). Products available in the market likely included both locally produced and external items (commodities as well as food). Because most Caracol households used their agricultural terraces to produce at least some of their own food, it is likely that the markets focused on specialty foodstuffs along with items of personal adornment, ritual materials, and quotidian goods.

Because the road system radiated out from the epicenter, some central control was likely possible. And while goods were available in the site epicenter, there was variability in materials available in different parts of the site. For example, the northwest portion of the city (that closest to Guatemala) exhibits slightly more Peten-like pottery from Guatemala, and the distribution of other types and forms recovered in archaeological contexts strongly suggests different availabilities in the various parts of the site (D. Chase and A. Chase 2014a, p. 246).

\section{Settlement}

Because of the close articulation with agricultural terraces, Caracol's residential groups are relatively evenly spaced over the landscape, resulting in a settlement that could be characterized as low-density agricultural urbanism (Fletcher 2009, 2012). However, based on numbers of residential groups and structures, population densities across the site's landscape were in the neighborhood of $600 / \mathrm{km}^{2}$ (A. Chase and D. Chase 1994; A. Chase et al. 2011; D. Chase et al. 2011), and settlement was continuous across at least $200 \mathrm{~km}^{2}$ (A. Chase et al. 2014a). The regular spacing of Caracol's residential groups contrasts with the clustered settlement found at other Maya sites like Copan (Andrews and Fash 2005). This spacing not only allowed sufficient area close to housing for agricultural production (A. Chase and D. Chase $2014,2015 a)$ but also averted some of the public health issues that predominate in close urban quarters (as indicated at Teotihuacan; R. Storey 1992, 2006). The presence of sustainable agriculture within the urban landscape made Caracol a truly "green" city (e.g., A. Chase and D. Chase 1996a, 2016; Graham 1999; Scarborough et al. 2012a).

The highest elite lived in Caracol's epicentral palaces and enjoyed a diet that was higher in meat and maize than other parts of the site, possibly partaking from a central kitchen (A. Chase and D. Chase 2001b, 2014). Status levels within the settlement were mixed, however, and high-status households were not solely located within or in close proximity to the epicenter. The diet of the bulk of Caracol's residents also was high in protein and maize - just not as high as the palace diet - a byproduct of residential group access to their own agricultural products from nearby fields. Yet some individuals, particularly those who lived in immediate proximity to the epicenter and other public areas, but outside the palaces, ate less maize and 
variable amounts of protein, suggesting not only that their specific jobs and household locations did not permit them to have easy access to their own crops (A. Chase et al. 2001) but also that they did not have the ability to procure these crops through the site's markets. Thus, there does appear to be an association between basic resources in the form of diet and status at Caracol, supporting societal stratification (Fried 1967).

\section{Agricultural Terracing and Sustainable Agriculture}

Stone-lined and soil-filled agricultural terracing covers most of the area between households at Caracol. The construction of this terracing involved removing soil and stone to bedrock and then reconstructing the landscape with stone berms and soil fill (A. Chase and D. Chase 1998a). It is telling that only one surface quarry is currently known from Caracol (ca. $0.5 \mathrm{~km}$ south of the South Acropolis); the others have been covered over with terraced fields. Studies in the 1960s of terrace soils and the presence of riverine snails in the terraces suggested that the soils in the Mountain Cow area (a part of Caracol) had been brought in from other areas, and it is likely that stone and soil were transported within Caracol. The Caracol landscape is almost completely anthropogenic (D. Chase and A. Chase 2014b). Soils were enriched, and water flow was controlled (see below). The spacing of plazuela groups at Caracol resulted in household access to 2.2-2.6 ha of land for crops, which would have fostered long-term agricultural sufficiency (e.g., Murtha 2009). It is assumed that proximity to households facilitated tending crops and provided ready availability to fertilization through the use of household waste and human night soil.

\section{Water Control}

Although bounded by rivers to the east and west, most settlement at Caracol is located at some distance and elevation from naturally available water resources. Monumental reservoirs were constructed in the epicenter of the site and at many causeway terminus groups; these were filled directly by rainfall as well as by the runoff from plastered plaza surfaces, aided by features like the drain constructed to fill the main epicentral reservoir. Hundreds of smaller reservoirs were constructed in association with household plazuela groups throughout the site, often at the edges of plazas that could act to catch and channel rain. Yet some reservoirs also were located within field areas and may have provided water for crops (A. S. Chase 2012). No household group had to travel far to access water.

The data on constructed reservoirs from Caracol strongly suggest that these features may have played a more active role in providing water in the southern lowlands, at least at some sites, than has traditionally been suggested (e.g., Scarborough and Gallopin 1991 for Tikal), something also proposed for northern Belize (Weiss-Krejci and Sabbas 2002). Caracol likely has more than 1600 of these small constructed reservoirs associated with residential groups (A. S. Chase 2016b; A. S. Chase and Weishampel 2016); some still hold drinkable water through the dry season. Many of the smaller reservoirs were not recognized and recorded in previous settlement surveys, and even when they were, their potential importance in 
providing water could be easily overshadowed by the more impressive, large reservoir systems that involved overflow features and filtration (Crandall 2009; Scarborough et al. 2012b). Thus, Maya models of elite power based on control of water ritual and water in large central reservoirs (e.g., Lucero 1999a, 2006) now need to take into account these smaller features that likely supported the bulk of the population in a waterless environment (see A. S. Chase 2012, 2016b).

\section{Household Production}

There is evidence for production activities within the various household plazuela units at Caracol. Different households specialized in the manufacture of different commodities, likely for distribution through the site's economic system (A. Chase and D. Chase 1994; D. Chase and A. Chase 2014a). While residential production may have taken place outside elite control, it is likely that the finished products were distributed at markets that were administered by elites (A. Chase et al. 2015). In some cases, the process and resulting products are evident, as in the case of bone (Teeter 2001; Teeter and Chase 2004), shell (Cobos 1994), chert (Johnson 2008; Pope 1994, 1996), and probably obsidian (Johnson 2016) workshops. In other cases, the specialized tools used to make commodities were found, while the end products themselves (such as wood, textiles, or basketry), being perishable, are not preserved in the archaeological record (e.g., A. Chase et al. 2008b). The byproducts of this manufacturing process are often not readily evident; rather, the residue often has been purposefully buried within the fill of structures. This is especially true for lithic debris (Johnson 2008, 2014; Johnson et al. 2015b); it can be a matter of luck to locate these materials (see also Moholy-Nagy 1997 for a similar situation at Tikal). In other cases, residue from obsidian, jadeite, and Spondylus workshops have ritual value and are redeposited in special contexts (e.g., in caches or above tombs) associated with specific ceremonies (D. Chase and A. Chase 1998; see also Johnson 2016). Whatever the case, most materials were manufactured in household locations and are found in both fill and ritual contexts and on floors within the site's residential plazuela groups.

\section{Administered Economy}

While surplus production at Caracol appears to have been undertaken within households, distribution took place in markets located in plaza areas within the site center and in conjunction with causeway terminus groups (as noted above). These markets provided access to both local items and to goods that were brought into the site from some distance. The market locations, which also provided necessary administrative services, were likely the primary "revenue" generators for the state. Both transactions and access to market locations were likely "taxed" by local elites, with the central Caracol administration receiving a portion of the transactions (A. Chase et al. 2015), much as is described for the Aztec (Smith 2014). The density of settlement, its place-bound nature, and the dendritic roads all served to enhance the ability of the epicenter to both provision and control the city and its populace. 


\section{Commemoration of Cyclical Time}

The earliest caches at Caracol provide windows into quadripartite and layered aspects of Maya cosmology and worldview, where three-world "layers" and five directions (including a central apex) are replicated (D. Chase 1988; D. Chase and A. Chase 1998; Mathews and Garber 2004). Ancient Maya history derived from epigraphy and the long-studied Maya calendar system not only provide a framework for archaeological research at Caracol and other Maya sites but also provide a window into ancient Maya views of time (Rice 2004, 2013). Placing monuments on katun (20-year period of time) endings is typical of most polity centers throughout the Maya Lowlands, but apart from these stone markers the recognition of these temporal cycles is difficult to see in the archaeological record. Yet, it is possible to document that time was very important to the Caracol Maya and that both the baktun (roughly 400 years) and katun cycles were commemorated through architecture and ritual.

The ceremonies to commemorate the beginning of the 8th baktun (8.0.0.0.0 in Maya long count) at Caracol involved reconsecrating and rebuilding the Temple of the Wooden Lintel (Structure A6), suggesting the significance of marking both the completion and initiation of long periods of time (A. Chase and D. Chase 2006a). Classic period monuments from Caracol further highlight the importance of cyclical time (Beetz and Satterthwaite 1981). Not only were stelae erected at appropriate 20-year katun endings, but Caracol specifically created and placed katun-specific altars (Satterthwaite 1951). The site's Late Classic period caches and human interments provide an additional dimension to the commemoration of time in that both caches and burials also appear to be placed in accord with certain intervals of time, such as katuns (A. Chase and D. Chase 2013a; D. Chase and A. Chase 2004a) rather than solely in association with the death of specific individual. It fact, it would appear that the majority of Caracol ritual was directly linked to the commemoration of cyclical time.

\section{Shared Identity}

During the Late Classic period, all Caracol households had access to similar ritual and symbolic items and participated in the same cyclical commemorations of time. In essence, they had a shared identity (D. Chase and A. Chase 2004b). Virtually every household had an eastern mortuary shrine with associated caches (finger bowls and face caches) and accompanying mortuary ritual; these caches are distinct from Caracol's censers, which are sometimes included in burials and also are found as terminal deposits in both the site epicenter and in some residential groups (see Rice 1999 who incorporated Caracol data on censers in her work). Three kinds of ceramic cache vessels have been found at Caracol. Both the earliest and latest cache containers tend to be barrel-shaped, larger in the Late Preclassic and smaller in the Terminal Classic. By far the most common cache forms are containers referred to as "finger bowls" or "face caches" (Fig. 12). Finger bowls are generally small, unslipped dishes that are set lip-to-lip and, if they have contents, contain human fingers. Up to 34 finger bones have been recovered in a single cache, from adults 

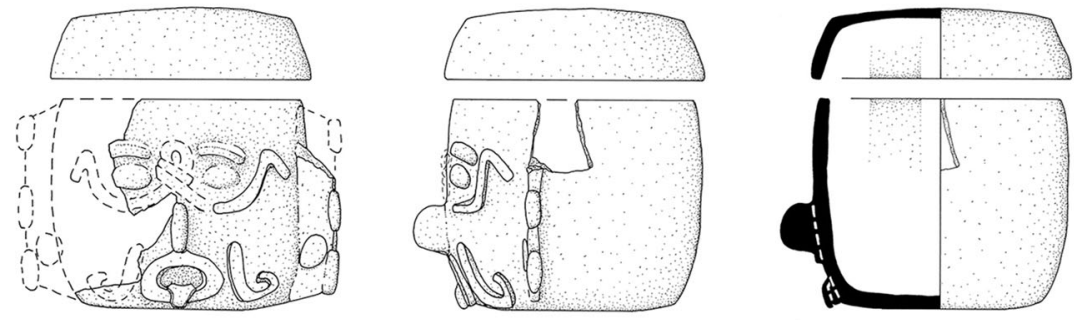

a
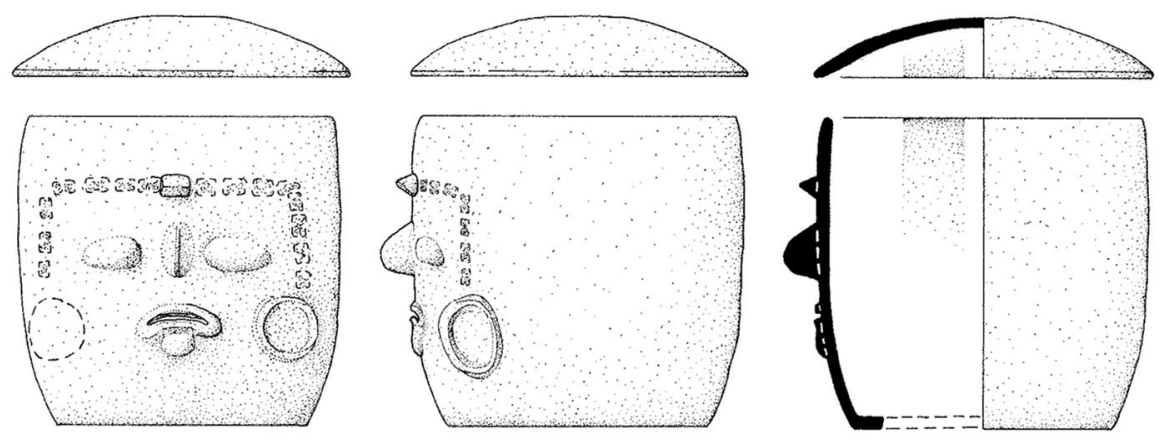

b

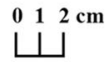

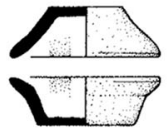

c

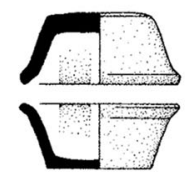

d

Fig. 12 Examples of residential "face" $(a, b)$ and "finger" (c, d) ceramic caches

and children. Face caches are generally larger ceramic urns, usually lidded, that exhibit a crude bird or, more often, human face sometime accompanied with modeled earrings. These caches are usually empty but sometimes contain a wide array of ritually significant materials (e.g., A. Chase and D. Chase 2010; D. Chase and A. Chase 1998; Johnson et al. 2015a). Given their stratigraphic associations, stylistic differences in the faces can be seriated into a cyclical katun sequence, showing that they were created and deposited on a 20 -year cycle.

Just as the ceramic caches are found throughout the site's settlement, so too is similar mortuary ritual that spanned status levels. Many Caracol residential groups contain formal tombs and burials that include multiple individuals (D. Chase 1994, 1997; D. Chase and A. Chase 1996, 2003b, 2011) who may have been deposited in accord with particular temporal cycles rather than immediately following the death of a particular individual; the remains from some of these individuals would have been curated for a period of time, possibly in the mortuary 
shrine, until an auspicious time for burial (D. Chase and A. Chase 2011). Also part of Caracol's shared identity was widespread personal adornment that included dental inlays and dental filing, both of which have been recovered in 71 out of 135 residential groups sampled archaeologically; overall (including individuals with no teeth and children), $15.8 \%(\mathrm{n}=116)$ of individuals display inlays and $14.2 \%$ $(\mathrm{n}=104)$ have filing. This compares to Tikal where six burials had inlaid teeth and 11 burials had filed teeth (out of 214 burials); Tikal's conservative percentages are $2.3 \%$ inlaid and $5.1 \%$ filed (Becker 1973, p. 401).

\section{Symbolic Egalitarianism}

Blanton and Fargher (2008; see also Carballo et al. 2014) have promoted the idea that governance in many societies focuses on collective action in which the will of the populace helps guide practical decisions; this is contrasted with a more hierarchical from of governance in which authoritative figures make decisions for the populace. Under collective action, people tend to receive more services from the government but more rules are required to maintain order. Blanton and Fargher (2008) see collective action as having the potential to be more democratic and not completely autocratic; we would argue that collective action also can be fostered by a hierarchical government as a management strategy. We have argued that Caracol's Late Classic society was governed and managed through a purposeful strategy of control that we have termed "symbolic egalitarianism" (A. Chase and D. Chase 2009; D. Chase and A. Chase 2006), a term borrowed from literature on business management strategies (Pfeffer 1994). In symbolic egalitarianism, outwardly visible differences in status (and compensation) are minimized and motivation to collaborate is increased. However, it is important to note that symbolic egalitarianism means that there are actual differences in wealth, status, and control. What appears to be collective action is actually a hierarchical strategy for societal control.

Not only did the people of Caracol share a ritual and symbolic identity, they also shared prosperity during the Late Classic period. While the quantity of items may have varied across status levels, all households at Caracol had access to imported obsidian, polychrome pottery, marine shell artifacts, and jadeite. Fueled by Caracol's market economy, this prosperity not only spurred Caracol's Late Classic period growth but also served as a viable management strategy for advancing the goals of the administrative elite. Caracol's inhabitants had access to materials that were restricted in other Maya polities, providing an incentive for population stability and/or growth and yielding a sufficient workforce to maintain the polity while also permitting the ruling elite to project little social, political, or economic inequality. Caracol's Late Classic market system fostered symbolic egalitarianism by providing the mechanism for all households to have access to the same goods and services, at least within their means. Because the markets were under centralized administration in terms of the distribution of goods and the taxing of transactions, tight control was actually maintained by the site's elite while giving the appearance of equality. This illusion of equality is also borne out in the widespread distribution of tombs, ritual vessels, and personal adornments such as earflares and dental inlays at Caracol. A breakdown in at least certain aspects of the market economy, 
including symbolic egalitarianism, is evident at the end of the Classic period and is a factor in Caracol's ultimate collapse.

\section{Terminal Classic Period and the Abandonment of Caracol}

The latest monument known from Caracol dates to AD 884. Within a decade, the epicenter of the site was abandoned and there was substantial burning on palace floors-whether from marauders or Caracol's own occupants is unknown-but depopulation of the epicenter was relatively rapid (D. Chase and A. Chase 2000). It is possible that populations continued to live in the surrounding settlement for some time; however, by AD 1000 there is no clear evidence of sustained occupation within the urban core.

Much speculation exists about the impact of extended drought combined with land exhaustion on the Classic Maya collapse (e.g., Aimers and Hodell 2011; Diamond 2005; Gill 2000; Haug et al. 2003; Iannone et al. 2014; Yaeger and Hodell 2008). Caracol provides an alternative view of this era in Maya prehistory. Caracol was abandoned during a time of increased rainfall and not drought (based on data in Kennett et al. 2012; also see Lachniet 2015 for possible issues with these data), although extremely wet and/or unpredictable conditions can impact agricultural sustainability as much as drought. Evidence at Caracol (as described below) is in accord with divergent scenarios that look at the broader context of the collapse (e.g., Turner and Sabloff 2012). For Caracol at least, it appears that other human-induced change led to site abandonment.

One hint to the collapse at Caracol lies in the site's Maya hieroglyphic texts. Toward the end of the Late Classic period, multiple changes occurred at Caracol, and the Terminal Classic period is characterized by marked differences from the preceding era. Just before AD 800, the hieroglyphic record, relatively silent during the preceding century, reappeared on stone monuments, providing a renewed focus on the Caracol dynasty (A. Chase and D. Chase 2007b). Many of the latest monuments at Caracol also differ from their predecessors in portraying two individuals rather than the ruler alone (A. Chase 1985; A. Chase and D. Chase 2015b; A. Chase et al. 1991; Grube 1994). Some show the presumed Caracol ruler in a scene of alliance with a lord from another site, while others show bound prisoners. To some extent, these scenes of collaboration, parlay, and subjugation mimic those found on modeled-carved ceramics of the Terminal Classic (A. Chase et al. 1991).

Even though the dynastic count continued into the Terminal Classic period with $\mathrm{K}$ 'an II being named as the 27 th ruler, it is very possible that there was a break in the sequence of rulers and a shift in the ruling dynasty. Two Late Classic tombs at the base of Structure B19 on Caana were desecrated at the beginning of the Terminal Classic, infilled with building materials, and then sealed beneath new plaster floors. A cache of Terminal Classic vessels was interred at the summit of the building. We would see these events as being linked to the political transition from one dynasty to a new one. 
These symbolic acts also foreshadowed a clear change in management style associated with Caracol's Terminal Classic power elite. The changes, however, are far more extensive. Not only did dynastic monuments reappear, but a greater separation developed between the elite and the rest of the population. Long-distance trade items, once available to all in at least limited quantities, were held only by the elite and not available to the population at large (A. Chase and D. Chase 2004), suggesting a breakdown in the market economy. No longer was there a shared identity, symbolic egalitarianism, or shared prosperity. Even ceramic traditions among Caracol's different status groups became segregated and distinct; the highstatus utilitarian and serving ceramics found on the floors of the latest palaces only rarely occurred in the surrounding residential groups (A. Chase and D. Chase 2004, 2007b). We would argue that just as socioeconomic changes that benefited the population at large helped support Caracol's rise, so too did socioeconomic changes that resulted in a great divide between the elite and the commoners incentivize its fall. Social tension was undoubtedly a factor in Caracol's final abandonment. Like all urban environments, Caracol was dependent on the existence of multiple complex organizational systems. A breakdown in one part of the system, as occurred to the site's economic system, would have had an impact on other parts of the system, presumably leading ultimately to unwanted consequences-in this case the abandonment of Caracol.

\section{How Research at Caracol Has Helped Change the Maya Paradigm}

To understand the impact of research at Caracol on Maya archaeology, we need to contextualize investigations within the changing field of Maya studies. When we started work at Caracol in 1983, there was a substantial database of archaeological research available to Maya scholars, but long-term work at a site using varied research designs was not common. The primary corpus of excavated materials available to Maya researchers was derived from the work of the Carnegie Institution of Washington at various sites_-particularly Kaminaljuyu (Kidder et al. 1946) and Uaxactun (Ricketson and Ricketson 1937; A. Smith 1950; R. Smith 1955) in Guatemala; Chichén Itzá (Morris et al. 1931; Tozzer 1957) and Mayapan (Pollock et al. 1962; R. Smith 1971) in Mexico-most of which had been widely critiqued by Taylor (1948) for their lack of a conjunctive approach. Other excavations were carried out by researchers at select academic universities throughout the 1950s1970s. The University Museum at the University of Pennsylvania had carried out major projects in Guatemala at Tikal (Coe 1962; Coe and Haviland 1982; Sabloff 2003) and Quirigua (Sharer 1978, 1990). We began our research at Santa Rita Corozal, Belize, under the auspices of the University of Pennsylvania in 1979, continued at Princeton University in 1984, and then at the University of Central Florida (D. Chase 1981, 1990; D. Chase and A. Chase 1988). The Middle American Research Institute at Tulane University had carried out archaeological research in Mexico at Dzibilchaltun (Kurjack 1974) and Becan (Webster 1976). The Peabody Museum at Harvard University had excavated at Barton Ramie, Belize (Gifford 1976; Willey et al. 1965), at Altar de Sacrificios (Willey 1973) and Seibal (Sabloff 
1975; Tourtellot 1988; Willey 1990) in Guatemala, and at Cozumel, Mexico (Freidel and Sabloff 1984; Sabloff and Rathje 1975) before moving to Copan, Honduras, where Fash (2001) continued research for decades. The New World Archaeological Foundation at Brigham Young University also had carried out longterm research in Chiapas, Mexico, and at El Mirador, Guatemala (Dahlin 1984). These institutions and the various sites that they had investigated formed the milieu and background for most interpretive works about the ancient Maya. The projects generally had excavated large central architectural precincts and incorporated settlement pattern study, a consideration of agricultural practices, and conjoined epigraphic and archaeological investigations (where practical) into their research designs.

In spite of all of these investigations and numerous advances in deciphering hieroglyphs, eliciting agricultural practices, and studying settlement, at the start of the CAP many aspects of ancient Maya society were still unclear. Even the chronological frame of reference for the Maya was still being addressed, both for the Preclassic (Coe 1965; Hammond 1985) and Postclassic (A. Chase and Rice 1985; Sabloff and Andrews 1986). While the spectacular art of the Classic period was well known and appreciated (e.g., Toscano 1944), models for the organization of Maya society were extremely variable, highlighting how little was actually understood, particularly relative both to the elite and to the relationship between the elite and the rest of society (D. Chase and A. Chase 1992). Thus, the archaeological work at Caracol was developed as a long-term investigation to understand the structure of ancient Maya society as a whole, by using material remains recovered from both settlement and epicenter archaeology in conjunction with the site's hieroglyphic history. Having worked at a Late Postclassic capital (D. Chase 1981; D. Chase and A. Chase 1988), we hoped that our research at Caracol could serve as a form of the direct historic approach in highlighting differences and similarities in ancient Maya society as we moved farther back into the archaeological past.

\section{History and Archaeology}

Research at Caracol has impacted Maya archaeology in a variety of ways. From the beginning, we have maintained a focus on the relationship between history and archaeology, which meant trying to correlate the hieroglyphic record with the archaeological one. This has proved both productive and problematic. As we did at Santa Rita Corozal (D. Chase 1981; D. Chase and A. Chase 1988), our intent has been to use archaeology not only to confirm but also to refine or potentially correct history. One place to start was the identification of rulers and the correlation of these rulers and their hieroglyphically described events with the archaeological record. While a dynastic list of rulers has been developed for Caracol (see above and Table 1), it is not possible to make a simple correlation of identified rulers with specific individuals in excavated elite tombs. The major structures in downtown Caracol have all been investigated and most have yielded tombs. Many of the excavated tombs in the Caracol epicenter (in Structure A6, Structure A4, Structure A7, South Acropolis Structure D16, Northeast Acropolis Structure B33) are earlier 
than the bulk of Caracol's historical record. Yet, five epicentral tombs and one terminus tomb are associated with hieroglyphic dates. There are two kinds of dates: those on capstones indicating when the chamber was closed and those on walls that are taken to be death dates (A. Chase and D. Chase 1996c, p. 219). On the summit of Caana, the central tomb in Structure B19 has a death date of 9.10.1.12.11 and the two dated tombs in Structure B20 have death dates of 9.5.3.1.3 and 9.7.3.12.15. The tomb at the base of Structure A37 in the Central Acropolis probably was closed in 9.7.8.12.12 (and reentered a century later) and the tomb in Structure L7 at the Machete Terminus was closed in 9.9.0.16.17. The tomb intruded into Structure A3 had the chamber sealed in 9.13.3.15.16 with the closure being witnessed by the Caracol ruler.

While the tombs with texts are the best candidates for royal chambers, none can be correlated with the individuals found on the site's stone monuments (A. Chase and D. Chase 1996c, p. 220; A. Chase et al. 2008a; D. Chase and A. Chase 2008). $\mathrm{K}$ 'an I acceded in 9.4.16.13.3. Yajaw Te' K'inich I acceded to the throne in 9.5.19.1.2 and is recorded as celebrating rituals on 9.8.0.0.0 and 9.8.10.0.0 (as a waterlily or "dead" lord). Knot Ajaw was born in 9.7.2.0.3 and had a ritual accession as "bleeder" in 9.8.5.16.12 (with Yajaw Te' K' inich I being reseated at the same time as "ahau"). K' an II was born in 9.7.14.10.8, acceded to the throne in 9.9.4.16.2, and died in 9.11.5.15.9 according to a stucco text on Caana. Thus, there is no possible correspondence between the rulers and the dated tombs. The tombs with texts all date to times when a given ruler was alive and in the mid-point of their reign. This is a very different situation than what is reported for Pakal at Palenque (Stuart 2005; Tiesler and Cucina 2006) or for Jasaw Chan K'awiil at Tikal (Coe 1990; Jones and Satterthwaite 1982), both of whom are associated with dated texts. The tombs that have been recovered at Caracol indicate many more significant individuals than are indicated in the hieroglyphic texts, perhaps suggesting that Marcus' (1992) view of Maya history as manufactured propaganda may have more applicability than we care to admit. Based on the excavated archaeological records, we have posited that Yajaw Te' K'inich II and K'an II are buried in the North Acropolis at Tikal, a direct result of the earlier A.D. 562 star-war.

In spite of the inability to correlate historically known individuals with their physical remains at Caracol, the hieroglyphic record has provided dates, events, and relationships that could be tested in the archaeological record, including the impact of warfare and the relationship of monument construction to site prosperity, as noted above. These studies further confirmed what we had noted at Santa Rita Corozal (D. Chase and A. Chase 1988) — that archaeology could provide a balance for and "correct" or refine history. Significantly, the time of Caracol's greatest prosperity correlates not with monument construction but with a period of silence in the site's hieroglyphic record near the end of the Late Classic period (D. Chase and A. Chase 2003a, 2004b). These topics are considered in greater depth below.

Because of the dated hieroglyphic data and importance of the recorded events, Caracol also has been instrumental not only in epigraphically based histories and discussions (Martin and Grube 2000, 2008; Schele and Freidel 1990) but also in considerations about the sizes and kinds of Maya polities (A. Chase and D. Chase 1996b, 1998b; Fox et al. 1996), as it provides a contrast with the hegemonic rule proposed by epigraphers (Martin 
and Grube 1995). The Caracol archaeological data also make it clear that Maya history cannot be categorized only as a struggle between Tikal and Calakmul (e.g., Martin and Grube 1995), especially since Caracol dominated Tikal for an extended period of time, as indicated in the hieroglyphic (Houston 1991) and archaeological (Coggins 1975) records of the sites. Laporte (1996, 1998, 2001; Mejia 2002) explicitly recognized the political role that Caracol played in regional organization of the southeastern Peten in his longterm project that defined the sites and settlements in that region. In combination with other archaeological data from the Peten of Guatemala, the Caracol archaeological information also has led researchers to more nuanced considerations of past political organization in the Maya area (e.g., Foias 2013).

\section{Importance of Women}

Prior to our work at Caracol, hieroglyphic and iconographic work had suggested that women might be important at the site (Sosa and Reents 1980; Stone et al. 1985). Individuals on Caracol monuments wore androgynous Maize god costumes (jade skirts and pubic Spondylus shells) that was gendered by many researchers as female, leading to arguments over whether these images showed women or men dressed as women (Arden 2002; Claassen and Joyce 1997; Joyce 2000, 2001). Irrespective of the interpretation of this iconography (possibly males wearing a female costume important in agricultural cycles; see Looper 2002), the archaeologically recovered epicentral tombs at Caracol demonstrate the significance of women. A woman was the primary individual in the central B19 tomb (A. Chase and D. Chase 1987, p. 26) and in the earliest tomb in Structure B20 (A. Chase et al. 2008b, p. 136; the later three tombs in Structure B20 were looted making gender identification difficult). Other women include the initial occupant of the Structure A34 tomb, (D. Chase and A. Chase 1996, p. 70), the Early Classic individual in Structure B33 in the Northeast Acropolis, and the individual in the early Protoclassic burial in front of Structure B34 (A. Chase and D. Chase 2005, p. 21). Women are found not only in elite tombs at Caracol but also in many of the tombs and burials in the site's residential groups, reflecting their overall status within Caracol society.

These data raise questions about the role of women in Classic Maya society and advance the possibility that there was variation in societal organization among the ancient Maya. Fox and Justeson (1986) once argued for a matriarchy in the Usumacinta Valley based on the hieroglyphic record. The importance of females in the major tombs of Caracol, as well as in other tombs in the site's residential groups, suggests that the possibility of matrilineal organization in certain parts of the Maya area may not be so farfetched. As at other sites in the southern Maya Lowlands, Caracol's monuments generally lack portrayals of women (except when shown as an ancestral parent), and the textual data on these carved stones contain limited data. Thus, while epigraphers and the epigraphic record tend to focus on a male-centered society because of the nature of their database (e.g., Martin and Grube 2008), the archaeological data (at least from Caracol) suggest that females were important to the functioning social order. 


\section{Status}

The identification of status differences among the Maya is another topic that Caracol has impacted, especially questions about who was and who was not elite (D. Chase and A. Chase 1992); a large proportion of the city were middle-status individuals (A. Chase and D. Chase 1996a). When we started work at Caracol, the presence of a tomb was considered indicative of the highest status in Maya society (Loten and Pendergast 1984, p. 9). Early on it became clear that tombs were too widespread at Caracol to be a sufficient marker of elite status (A. Chase 1992), as they likely were present in at least $70 \%$ of the site's residential groups. The presence of inlaid teeth also was considered a status indicator (e.g., Becker 1973; Williams and White 2006, p. 148); again the Caracol data suggest a more complex picture. As noted above, the proportion of Caracol burials with dental inlays and/or filing (20.8\%; $n=152$ of 732 individuals) was much higher than at Tikal. Dental inlays appear to have been available to all levels of Caracol society, as individuals with jadeite and hematite inlays are found throughout the full spectrum of Caracol burials; many individuals with jadeite inlays simply were placed in structural or plaza fills. Dental inlaying continues to be assumed to coincide with elite status; in a recent publication Scherer (2015, p. 123) notes "jade encrustations that seem limited to Maya elite." Realistically, much of the data published on these dental practices are problematic because they are derived from selected, small samples; even the landmark study by Tiesler (1999), which examined 1515 individuals from 94 different sites, is problematic because of the small selective samples that were available per site (with the exception of Copan). Given that dental modification was widespread at Caracol, and likely more broadly in ancient Maya society, dental inlays in and of themselves cannot be used a marker of elite status. Also, two Caracol children under age 10 have inlay holes (see 2001 field report at www. caracol.org). These data contradict assertions by both Tiesler (1999) and Scherer (2015) that inlaying only occurred after adolescence.

While the presence or absence of inlays alone does not appear to suggest status or privilege, it is possible that future research will find that the quantity or patterning of inlays was significant. The woman in the Structure B19 tomb had jadeite inlays over half of her maxillary teeth, raising the question of whether particular patterns of inlay projected certain meanings (D. Chase 1994, p. 132). Tiesler (2014, p. 21) also suggests that "Ik" patterns of dental filing, in which central incisors mimic a "T" shape representing the Sun god, may correlate with status; However, at Caracol, Ik filing patterns appear to be associated with certain residential groups or neighborhoods. With further work it also may prove possible to use details in dental inlay patterns to determine whether variation in the decoration was specifically correlated with personal beautification, specific occupation, and/or status. The Caracol data suggest that these questions are best answered with large contextual samples.

A series of other items have been suggested to be status indicators. Residence distance from the site epicenter or from a causeway does not appear to correlate with status (Jaeger 1987, 1991; Jaeger Liepins 1994). While it is sometimes suggested that both polychrome pottery cylinders (Coggins 1975; Reents-Budet 
1994; see also Callghan 2014) and the crafting of jadeite objects (Inomata 2001; McAnany 2010, pp. 298-300; but see Rochette 2014) were in the purview of the elite, these markers cannot be taken as indicators of elite status at Caracol, especially as these items were widely distributed and not restricted to palace locations; it is highly likely that both items were available through the market system. Specific artifact types, such as jadeite or obsidian earflares, however, are more limited in distribution and correlate with the more important burials, presumably representing higher status. Mid-status individuals used shell earflares, which are distributed among many of the residential groups at Caracol, consistent with the mixed statuses of Caracol residential groups in any given area. As mentioned above, difference in access to basic resources (e.g., Fried 1967) is reflected in the Caracol stable isotope studies; thus, diet also appears to have been correlated with status; the diet eaten by the site's elite was distinctive and signaled more access to maize and protein than is found among other parts of the society (A. Chase and D. Chase 2001b).

The focus on recognizing status differences in the archaeology at Caracol led to our interest in redefining Mesoamerican elites and looking at other levels of ancient Maya society (D. Chase and A. Chase 1992). The societal complexity seen at Caracol has been noted by other scholars (e.g., Fash 1994, p. 191; Lucero 1999b, p. 229) and has driven research into ancient Maya social complexity, as is particularly evident in Maya Commoners (Lohse and Valdez 2004), which stressed the variability in the nonelite individuals who formed the bulk of Maya society. The complex social situation at Caracol also has been recapitulated in introductory texts (Demarest 2004; Sharer and Traxler 2006). In general, the Caracol data have resulted in the determination that Maya society was not a simple two-level system but instead comprised a rich social tapestry that included a variety of middle socioeconomic levels (Becker 2003, p. 269; A. Chase and D. Chase 1996a; D. Chase and A. Chase 1992; Jaeger 1991). Most recently William Ringle and George Bey (in a National Geographic Special titled "Quest for the Lost Maya" that first aired in 2012) also have argued that Late Classic Maya society in the northern lowlands also comprised well-to-do middle social levels. The richness of the archaeological record at Caracol, in terms of the number of burials, tombs, and cache deposits recovered from residential groups (e.g., D. Chase and A. Chase 1996, 1998), also helped lead to a renewed interest in Mesoamerican household ritual (e.g., Gonlin and Lohse 2007) and even to the application of kinship to the archaeological record (Ensor 2013, p. 1).

\section{Subsistence and Economy}

Another area in which Caracol has had a significant impact is in the demonstration of the intensity of agricultural terracing at the site. Healy and his colleagues (1983) originally reported on the terracing and high population densities at Caracol, but their limited sample was unable to convey the ubiquitous nature of Caracol's agricultural terracing. The CAP focused on trying to document the agricultural terracing and, while recording most of the terracing between the Conchita and 
Pajaro-Ramonal causeways by 1989 , was similarly overwhelmed and unable to adequately demonstrate how much of the site's landscape was covered with terracing. During a second season of settlement pattern work in the northeast sector of the site, $2 \mathrm{~km}^{2}$ of terracing was recorded and published (A. Chase and D. Chase 1998a), demonstrating conclusively how the Caracoleños were able to feed and support themselves over the long term (see also Murtha 2002, 2009). Many scholars used these data as examples of Maya intensive agricultural practices (Beach et al. 2002, pp. 387, 389; Dunning et al. 1998, p. 94; Fedick 1996) but, again, the sample size was problematic. Not until the 2009 LiDAR imagery was obtained could it be conclusively demonstrated that at minimum $160 \mathrm{~km}^{2}$ of Caracol was both densely occupied and intensely covered in agricultural terracing (A. Chase et al. 2011), yet another indication of the great impact of long-term research; the $2013 \mathrm{LiDAR}$ imagery increased this area to $200 \mathrm{~km}^{2}$ (A. Chase et al. 2014a).

With such an extensive population and a landscape covered with agricultural terraces, locations were needed to carry out site-level administration and to provide areas for assembly and potential transactions. The size, extent, and density of population at Caracol would have necessitated efficient and distributed mechanisms to facilitate commerce. Mapping identified the large plazas at the ends of Caracol's causeways as the only spaces that were appropriate for such activities. These large plaza areas were lined with low range-like buildings, were regularly distributed over the Caracol landscape, and were connected to the epicenter by roads; excavation in these areas did not encounter ritual items or burials. The artifactual distributions at Caracol, particularly the widespread distribution of "prestige items" (e.g., McKillop 2006, p. 114; Sharer and Traxler 2006, p. 657) in most residential groups, also suggested that there had to be particular areas in which these items were being obtained; thus, the large plazas in the terminus groups were recognized as potential market areas and Caracol impacted the study of ancient Maya economies.

Different residential groups focused on the production of specific products that could be exchanged for other needed goods at the market locales. Even though most of Caracol's residential units were self-sufficient in terms of basic agricultural supplies, isotopic testing of at least one of the site's market plazas demonstrated the likely presence of organics at that locale, consistent with what Terry et al. (2015) view as a food market. We would view the Caracol markets more as places in which a panoply of both local and imported goods were available to the general inhabitants, with the transactions being monitored and presumably taxed by the state (see Smith 2014).

The presence of administered marketplaces at the site (A. Chase 1998) and the fact that Caracol had "a solar market organization" was incorporated into early discussions of markets among the ancient Maya at a time when they were not explicitly recognized (Masson 2002, p. 4). The identified plaza spaces also were explicitly searched for, in most cases successfully, at other sites in both the Peten (e.g., Bair and Terry 2012) and Belize (Cap 2015). The existence of markets at Caracol also underlay Dahlin et al.'s $(2007,2010)$ arguments for markets in the Maya area, and the chemical testing done by Terry et al. (2015) to demonstrate organics at many of these locales was eventually accomplished at Caracol (A. Chase et al. 2015). The same set of factors (configurational, contextual, and distributional) used by Hirth (1998; Hirth 
and Pillsbury 2013) to demonstrate the existence of markets in highland Mesoamerica may be utilized to show the existence of markets at Caracol.

\section{Warfare}

Conceptions concerning Maya warfare have shifted over the course of our archaeological work at Caracol and also have been impacted by the interplay between history and archaeology. When we started work at the site, ancient Maya warfare was viewed as largely ritualized and only involving the elite (e.g., Freidel 1986). After finding Altar 21, which indicated that Caracol was involved in an earlier successful war against Tikal (A. Chase 1991; A. Chase and D. Chase 1989), our research focus logically turned to documenting the impact that successful warfare had on the site. We first analyzed these texts for the kinds of war events that were indicated in the hieroglyphs and the temporal order in which they took place. The Caracol hieroglyphic record specifically noted star-war events, thought to represent all-out war, at both Tikal in AD 562 and at Naranjo in AD 631, as well as a series of jubuuy or jub-i- “downing" or "toppling" or destruction-events that preceded the star-war with Naranjo. The inscriptions, spatial distance, and, in the case of Tikal, excavations provided clues to the impact of aggression at both Tikal and Naranjo. The AD 562 war with Tikal, $76 \mathrm{~km}$ distant from Caracol, appears to have led to a series of dramatic consequences for Tikal: a dynastic upheaval accompanied by monument destruction, the cessation of monument erections for 130 years in the site epicenter, and a decrease in the population of outlying residential settlement (Puleston 1974, p. 309). The effect of the AD 631 warfare at Naranjo, $42 \mathrm{~km}$ distant from Caracol, appears to have been a cessation of Naranjo monuments with Caracol probably erecting its own monuments at that site (Houston 1987; Schele and Freidel 1990). Military theory posits that extended territorial control cannot effectively exist beyond 3 days marching distance, or $60 \mathrm{~km}$ (Hassig 1992); thus we surmised that Naranjo likely served as a second capital for Caracol from which Tikal could be territorially controlled (A. Chase and D. Chase 1998b) at least for a period of time. We would now see a more direct impact at Tikal by Caracol in which two Caracol rulers were ritually interred in the heart of that site.

We also have mined considerations of warfare to determine what effects successful warfare could have on a society (Arkush 2008; Keeley 1997; Le Blanc and Register 2003; Nielsen and Walker 2014; Otterbein 1973, 2009; Webster 2000). The literature points to three potential results: the organizational integration of a society (because of mobilization of necessary resources), more prosperity for that society (the benefits of being the winner), and an influx of people who have sensed the well-being of the victor or are forcibly moved.

With these potential outcomes in mind, we operationalized these impacts and used Caracol's residential settlement to test for changes in occupation, prosperity, and integration relative to the periods of war with Tikal and Naranjo, focusing first on the southeast portion of the site and later on other sectors (D. Chase and A. Chase 2000, 2002, 2003a). As mapped, some 70\% of Caracol's residential groups contain an eastern building whose surface configuration suggests that it functioned as a 
shrine. Excavation indicates that these eastern buildings followed a standard pattern of ritual deposits and were usually associated with a tomb. Because of Caracol's propensity to utilize ceramic vessels within their ritual deposits (as noted above), we were able to tightly date Caracol's residential groups. This residential plan, focusing on an eastern mausoleum, appeared rapidly over the landscape at the beginning of the Late Classic period, precisely at or following the warfare with Tikal and Naranjo. This pattern culminated in the middle of the Late Classic period with a residential settlement that covered $200 \mathrm{~km}^{2}$. The tombs in these residential groups contained impressive ceramics and other artifactual materials, such as carved shell. Ritual caching of finger bowls and faced pottery urns occurred in most of these groups. Obsidian blades were common artifacts recovered in all residences and some $41 \%$ of the groups investigated yielded jadeite. The distribution of ritual patterns and imported artifactual materials within Caracol's households was taken to indicate a high level of prosperity for this society, one that was not generally found in other Maya sites. It also indicates that the general population of the site had access to quotidian, ritual, and prestige goods through Caracol's system of markets. The spread of this prosperity over the landscape also coincides with population growth on the order of $300 \%$ over a relatively short period of time (A. Chase and D. Chase 1989) based on the dating of excavated residential deposits. This suggests a population influx at the site, but we have yet to test for population origin through isotopic analyses.

The organizational integration of the site, one of the other outcomes correlated with successful warfare, can be seen in the Caracol causeway system. Much of this system came together precisely at the beginning of the Late Classic when this warfare occurred. In particular, three large plazas-Conchita, Ramonal, and Puchituk - that constituted public space were embedded in the landscape, each approximately $3 \mathrm{~km}$ from the site epicenter. The causeways linking the Caracol epicenter to the existing sites of Ceiba and Retiro were likely built at this time and helped integrate a vast expanse of territory. Causeways constructed even later in the Late Classic further expanded the reach of Caracol's integrative causeway system. Thus, another outcome of successful warfare is corroborated in these archaeological data.

Not only is successful warfare associated with typical outcomes that should be visible in the archaeological record, but so too should the impact of defeat be visible. The establishment of a correlation between archaeological data and warfare relies on the hieroglyphic interpretation of these events and the severity of the conflict. Accepting that a star-war constitutes a major war in which a ruling dynasty is removed from a site means that the result of such an event should be detectable in the archaeological record of the defeated site. The impact of such warfare on the epigraphic record is clear; Tikal had a loss of outlying residential population and did not erect monuments for 130 years after the AD 562 war (A. Chase 1991; Puleston 1974; but see Moholy-Nagy 2003), and Naranjo did not erect monuments for 71 years after the $\mathrm{AD} 631$ conflict (although there is a retrospective dating to $\mathrm{AD}$ 682) (Houston 1991). The Naranjo star-war against Caracol in AD 680 had much the same impact at Caracol, even though the Caracol ruler returned to the site 168 days later (Grube 1994) and a slate stela was erected in AD 702 (possibly 
exhibiting a captive from Pacbitun, Belize; Helmke and Awe 2012). While the expansive population at Caracol showed little impact from this event, the political impact of the Naranjo star-war in 9.12.7.14.1 was profound in terms of the site's efforts at dynastic expansion. While Caracol's ruler K'ahk' Ujol K'inich II (aka Smoke Rabbit) "returned" to the site in 9.12.8.4.9 (AD 680), the site's political dominance in the central Petén of Guatemala was over, given the turn of political events recorded in the hieroglyphic record. Jasaw Chan K'awiil acceded at Tikal in 9.12.9.17.16 (AD 681) and reestablished visible rule at that site after an extended epigraphic hiatus. The arrival of Lady 6-Sky at Naranjo in 9.12.10.5.12 (AD 682) also reestablished a ruling dynasty at that site.

The impact of the Naranjo star-war at Caracol is also reflected in the spatial distribution of carved stone monuments bearing K'an II's history at other sites. The presence of a lintel and multiple stair blocks at Naranjo referring to K' an II suggests that K'an II constructed a building at that site covered with his textual history. After the AD 680 star-war, this building was likely demolished with the textual material rearranged in an unintelligible hieroglyphic stair at Naranjo; glyphic style in these blocks suggests that two different texts were interspersed as one. Parts of these texts are still missing, with at least one block moved to Ucanal, a site subject to Naranjo by $\mathrm{AD} 698$ (Houston 1983). Other textual materials relating to K'an II were transferred to Xunantunich (Helmke and Awe 2016a, b), again a site in Late Classic alliance with Naranjo (LeCount and Yaeger 2010). The rectangular slabs with vertical cartouches recovered at Xunantunich do not match other parts of the Naranjo stair in form, suggesting that these texts were not associated with the Naranjo stairway or that the Naranjo stair blocks were reworked from similar slabs into their current form. In either case, the spatial dispersion of these textual references related to Caracol's K'an II and the purposeful mixing of the textual blocks in a publically visible hieroglyphic stairway at Naranjo demonstrate the importance of defusing and mitigating the charged cosmological meaning of this carved stone writing.

What the archaeological data from Caracol demonstrate is that events in the hieroglyphic record may in fact be correlated with archaeological data. Successful Maya warfare did have the expected theoretical impact on the ancient Maya. Following the Tikal and Naranjo wars, there was a population boom at Caracol and this population experienced a level of general prosperity and access to both goods and ritual that was not encountered at most Maya sites. Caracol was also tightly integrated by means of a causeway system that provided access to a variety of goods for the broader population. This same causeway system also permitted the deployment of warriors from one end of the site to the other, something directly correlated with an integrated road system (Trombold 1991). A management strategy of symbolic egalitarianism at Caracol provided a social identity to the site's inhabitants that emphasized their access to ritual and goods. Thus, at Caracol, successful warfare, in conjunction with other aspects of Caracol such as city planning and a market economy, helped promote economic and social practices that resulted in a massive, yet effective, urban structure. These data demonstrate that, while there may have been sacred aspects to warfare, there were practical consequences as well-for both the 
"winners" and the "losers" —emphasizing some of the real world implications of our archaeological data.

\section{Maya Urbanism}

The nature and structure of urbanism in ancient societies in general and within Mesoamerica specifically has been the subject of much discussion (e.g., Cowgill 2004). Initially, tropical environments were believed to be unsuitable for the development or maintenance of urbanism (Meggers 1954; but see Coe 1957). Several factors contributed to a general view that the Maya were less complex than their northern neighbors in central Mexico and were not truly urban (e.g., Sanders and Webster 1988; but see D. Chase et al. 1990; Smith 1989): an incomplete understanding of the scale and variability of Maya sites (A. Chase et al. 2014a) combined with the early investigation of sites with smaller populations in the southern lowlands (e.g., Piedras Negras [Weeks et al. 2005] and Copan [Andrews and Fash 2005]), a lack of recognition of the variation in naturally available resources within the Maya Lowlands (Sanders 1973) and of their economic system (subsequently corrected by Dahlin et al. 2007; Feinman and Garraty 2010; Garraty and Stark 2010), and to some degree expectations that urban forms should fit Western models (see discussion by Smith 2007).

Whether or not the Maya were urban continues to be contested. The Caracol data have been particularly influential in shaping much of this debate, contributing to our understanding of city planning and to the complexities of local populations and politics. At a time when some Mesoamericanists were arguing that Maya sites were "regal-ritual" centers (Sanders and Webster 1988), implying a less than urban status, the archaeological data from both Caracol and Tikal, Guatemala, were used to demonstrate a much more complex social situation that was consistent with urbanism (D. Chase et al. 1990; Haviland 1970). M. Smith (2007, 2010a, b, 2011) has since undertaken substantial research on ancient urbanism and demonstrated the diversity that existed in cities and urban planning in antiquity. While Fletcher (1995) had postulated the existence of something termed "low-density agricultural urbanism" based on his research in Africa and Southeast Asia (and suggested for the Maya), this form of urbanism (Fletcher 2009, 2012) only became more widely accepted and recognized through the application of remote sensing at Angkor, Cambodia (Evans et al. 2007, 2013), and at Caracol (A. Chase et al. 2011, 2014a). It now appears that some tropical civilizations developed a form of urbanism predicated on the practice of agriculture within urban confines, leading to a more dispersed population at densities that were generally at least 1000 inhabitants per square mile (Fletcher 1995, pp. 166-173); ancient Maya population densities easily match this figure (see A. Chase and D. Chase 2016 for two variants of Maya urban forms dependent on agricultural practice); this kind of urbanism is also embraced under the terms "garden" and "green" cities (A. Chase and D. Chase 1996a; Graham 1999; Scarborough et al. 2012a). Low-density tropical urbanism (which is still a significant density; D. Chase et al. 2011) differs from urbanism found in much 
of Europe and the Near East that focused on dense population concentrations in limited spaces with agriculture outside the urban limits.

Caracol was an integrated urban city. Residential settlement and agricultural terraces are continuously distributed over the landscape, encompassing some $200 \mathrm{~km}^{2}$ of integrated space. Not only is the landscape in this area almost completely modified, but a semblance of urban planning can be seen in the placement of markets and their dendritic connection to the site epicenter via an extensive road system. Even with the agricultural fields embedded in the residential settlement, the density of settlement at Caracol is similar to current suburban landscapes (D. Chase et al. 2011, p. 66). As noted above, the development of this city is possible to ascertain because of the excavation that has been undertaken at the site. Other research undertaken in the Maya area makes it clear that Caracol is not unique in terms of its size and scale; Tikal in Guatemala (Puleston 1983) and Calakmul (Folan et al. 1995) and Coba (Folan et al. 1983) in Mexico share similar characteristics in terms of settlement and size. Furthermore, the growth of Caracol as a city follows patterns of growth that are similar to those found in modern cities, including support staff living next to the city center (Burgess 1923), the infilling of the landscapes following roads and of the need for administrative and market nodes much like that described by Garreau (1991) for edge cities (A. Chase and D. Chase 2007a), mixed status-level settlement characteristic of walking cities (Rothchild 2006; G. Storey 2006), and eventually the urban sprawl similar to what is seen in today's megacities (Gottman 1961; Smith 2010a).

However, Maya urbanism did not follow a standard formula but appears to have been shaped by sociopolitical policies that were promulgated at different large sites. If one compares Tikal with Caracol, it is evident that there were significant differences between these two cities that is reflected in their urban layout, archaeological records, and even hieroglyphic texts. Caracol used a variant emblem that does not focus on naming the highest lord as "ahau" (e.g., Houston 1986), whereas Tikal always named the highest lord as an "ahau" in their emblem and also sometimes referenced an overlord (Martin and Grube 2008). The higher and wetter climate at Caracol (A. Chase et al. 2014b) made agriculturally intensive infields possible at that site. The Tikal landscape was not significantly transformed for agriculture, rather bajo edges were used for more intensive agriculture (Lentz et al. 2015; Murtha 2015). In contrast, the entire Caracol landscape was engineered with agricultural terracing (A. S. Chase and Weishampel 2016; D. Chase and A. Chase 2014b). While 47 smaller reservoirs are known from the surrounding Tikal landscape, there were 15 large reservoirs at Tikal that were centrally located with sizable capacity (Scarborough et al. 2012b). This differs significantly from Caracol where minimally 1590 built reservoirs supplement the eight larger reservoirs associated with public architecture (A. S. Chase 2016b), benefitting and sustaining the broader population of the site.

At Tikal the elites, their monumental architecture, and their road systems appear to have been more concentrated than at Caracol. Tikal's causeways bound a system of large dynastic temples to the central public space. In comparison, Caracol's causeways integrate a huge urban area, providing a series of large open plazas with nonpermanent range buildings that served administrative and market purposes for the population at large. Tikal's temples were the focal architectural points of the 
city, visibly signifying both elite power and probably a state religious focus. Tikal's temples were publically accessible and only a few private shrines could be detected in the site's residential groups. In contrast, Caracol constructed not only public temples but also private shrines that were integrated into the majority of the residential groups at the site. Whereas the markets at Caracol were widely distributed and potentially under more localized control with some central oversight, the imposing stone market at Tikal (Becker 2015; Jones 2015) was positioned in the center of the site and appears to have been utilized as a source of dynastic power and control. This contrasts with the focus on collective action that is present in the Caracol data. Although elite power was evident in the siting and massive form of Caana, the widespread distribution of Caracol's markets appears to have promoted the public good in terms of the dissemination of commodities and resources.

At Caracol, religion was not narrowly focused on the dynastic line but rather on the temporal order of which all were a part. It is explicitly evident in Caracol's emphasis on marking the passage of cycles of time in its archaeological record (see above) in contrast to the archaeological records of neighboring centers (e.g., Minaha [Iannone 2005] or Cuevas [Moyes et al. 2015]). It also can be seen in comparisons of Caracol and Tikal. Censers at Tikal are concentrated in the site center and reflect dynasty (Rice 1999); at Caracol they occur in both residential groups and public architecture. The differences in household layout at the two sites similarly reflect religious differences; $14 \%$ of Tikal's groups had an eastern shrine (Becker 2004, p. 129), whereas $70 \%$ of residential groups at Caracol had their own eastern shrine (A. Chase and D. Chase 2009). Tombs also reflect these differences. At Tikal, 20 tombs have been reported, all in the site epicenter (Coe 1990). At Caracol, 25 tombs have been excavated in the site epicenter and 95 other tombs have been investigated in 66 different residential groups. At Tikal, residential caches were not generally made in specially prepared ceramic containers; at Caracol, formal caches within ceramic containers have been recovered in 72 different residential groups. While we now generally recognize the Maya as having cities, the variation that existed in these centers is readily apparent, even among sites less than $100 \mathrm{~km}$ apart. Thus, sociopolitical organization at Tikal and Caracol was significantly different and speaks to the cultural diversity that existed in urban forms in what had been previously viewed as a fairly monolithic Maya culture.

\section{Foreign Relations and Interregional Interactions}

The scale of Caracol "the city" changes the way we view the ancient Maya. While Caracol engulfed formerly independent centers within its metropolitan boundaries, the Caracol polity would have incorporated other smaller urban centers beyond the city limits. We can project polity size and extent from hieroglyphic texts and archaeological remains. Thus, nearby sites like Caballo (A. Chase et al. 2014a) and Minanha (Iannone 2005) to the north were probably located within the Caracol polity during the Late Classic period. Given that Naranjo became a second capital in the early part of the Late Classic period, sharing hieroglyphic texts and dates with Caracol, and that Caracol rulers were buried at Tikal, the Caracol polity presumably 
extended at least that far north and probably also encompassed the Belize Valley for part of the Late Classic period (based on the presence of finger bowls at Cahal Pech and Baking Pot, indicating ritual similar to that found at Caracol; see also Helmke and Awe 2012). However, the territory may not have been as important as the political, social, and economic connections (A. Chase et al. 2009). Thus, until the beginning of the late Late Classic period, Caracol would have controlled politically a sizable portion of the southern Maya Lowlands. While the full size of the Caracol polity may be difficult to discern, its impact is not.

That Caracol had a long history of interregional interaction is reflected in its archaeological record. Early caches contain shells that came from the Pacific Coast (Cobos 1994), and the ceramics show elite connections to the Guatemala Highlands by AD 150 (A. Chase and D. Chase 2005). These external connections likely led to long-standing trade relationships with sites outside the Maya area, including the burial of an individual in Caracol's Northeast Acropolis by AD 350 in a style similar to elites at Teotihuacan in central Mexico (A. Chase and D. Chase 2011). Importantly, this connection appears to have taken place before the hieroglyphic entrada mentioned on stone monuments in the northern Petén and dated to AD 378 (Schele and Freidel 1990; Stuart 2000). For much of the Late Classic period, Caracol was a dominant force in the southern Maya Lowlands. In the Terminal Classic period, Caracol again sought to interact on an interregional stage; this is reflected in the iconography and the artifactual materials from the site. The ceramic repertoire includes a wide variety of modeled-carved markers (A. Chase and D. Chase 2007b) that were traded into the site, as well as distinctive items from northern Belize and from places even farther afield (A. Chase and D. Chase 2013b). These late interactions, however, were for the benefit of the elite rather than the collective population.

\section{Conclusion}

From the very first season of fieldwork, investigations at Caracol have had an impact on how we view the Maya world. Several research strands have dominated our archaeological efforts: a contextual approach to the archaeological record and its interpretation; a conjoined view of history and archaeology that attempted to test, refine, and sometimes challenge the epigraphic record; a focus on settlement study that examined the site epicenter and core, urbanism, and relationships between humans and their environment; and the reconstruction of ancient Maya ritual, social structure, and economy at Caracol. As a result, we have documented an ancient Maya society that is both similar and distinct from the coeval Maya society that was documented through long-term archaeological research at Tikal, stressing the diverse sociopolitical organizations that coexisted among the ancient Maya during the Classic period.

Our contextual approach, incorporating history and archaeology with large-scale settlement study and long-term excavation, sometimes led to different or controversial interpretations of the past, some-but not all —of which have become more mainstream over time. These include interpretations of the Maya of Caracol as 
urban; recognition that tombs were not limited to the elite; documentation of the existence of prominent middle-status social levels rather than solely elites and commoners; identification of the built spaces as a model green city with sustainable agriculture, road systems, and markets; acknowledgment of the utility of using ceramics and other material indicators to identify coexisting status-linked assemblages; discovery that the success of the city was directly related to shared prosperity based on shared economic and ritual practices and that decline was based on a contrasting disruption in previous practices rather than solely the impact of climatic change; and the acceptance of the role of cyclical time in the construction of monumental architecture and in the deposition of ritual caches and burials.

We stress that this work was accretional. The known size of the settlement area grew over time as on-the-ground mapping slowly progressed, but it was only with LiDAR that is was possible to document the actual size of some Maya cities. Two LiDAR campaigns at Caracol showed a city that spanned $200 \mathrm{~km}^{2}$ (A. Chase et al. 2011, 2012, 2014a) and also established the enormity of landscape modification efforts undertaken by the ancient Maya-road systems, agricultural terracing, reservoirs, household plazuela units, and civic-ceremonial space. Together, excavations and settlement survey revealed the changing nature of social, ritual, and economic relationships among the various parts of the site over time that, combined with hieroglyphic texts, provided a nuanced picture of the ancient landscape and people.

Research at Caracol has largely removed a Tikal-centric focus from Maya archaeology; this began with the 1986 discovery of Caracol Altar 21 that contained a text delineating that site's defeat in a star-war in AD 562; it continued with the longterm research at Caracol that ultimately demonstrated the existence of a very prosperous population living amid their fields in a larger and differently organized contemporary city. These archaeological investigations also have led to an investigation of the variation present in the Maya area and to an exploration of the social differences within their societies. Landscape research at Caracol has led to a radically different focus on Maya urbanism through the recognition of the enormity of the site's settlement, the complexity and scale of environmental modification, and the possibility of a Late Classic diminution of divine kingship. The attention given to the integration of texts and archaeology within the research design has resulted both in a changed perception of Maya warfare and in the recognition that the ancient Maya embedded material indicators of cyclical time within their archaeological record.

Caracol provides an example of an ancient city and polity that developed innovative solutions for developing sustainable urbanism through the use (or exploitation) of collective action. These solutions are visible in the site infrastructure of radiating causeways, the site's mixed status neighborhoods, the placement of the integrated but distributed market system, and in the socioeconomic practices of shared identity and symbolic egalitarianism. Caracol also provides an example of the effects that human actions can have on a once-functioning infrastructure. The rejection of collective action and the previously used management strategies of shared identity and symbolic egalitarianism during the site's latest phase led to a dysfunctional urban settlement. The breakdown in Caracol's socioeconomic system during this era first led to the creation of a divide between the site's elites and the 
rest of the population and then to the collapse and abandonment of this once-great city.

When viewed in totality, the research at Caracol provides testimony for long-term concentrated efforts at a single site as a way to gain a deeper and more comprehensive understanding of an ancient people. Most importantly, however, this work showcases what we can do with archaeology - the breadth of questions we can answer with context, appropriate sample size, new techniques, and operationalized material impacts of behaviors. Significantly, archaeological research can challenge both historic and contemporary thinking about questions of relevance to the modern world.

Acknowledgements The Caracol archaeological database has been compiled since 1983, beginning before the current computer age. The early database exists in paper notebooks, drawings, and a card system similar to the one utilized by the Tikal Project (and continues to be utilized today). For the last 15 years we have been attempting to digitize the Caracol data (drawings, notebooks, card systems, and summaries). Artifactual materials deriving from special deposits are stored in Belmopan at the Institute of Archaeology, while the bulk of the excavated materials are stored in laboratories at the site. Copies of field season photographs and drawings are stored at the Institute of Archaeology. Detailed reports for each archaeological field season since 1996 may be found on the Caracol website (www.caracol.org); earlier field seasons are summarized in two monographs (A. Chase and D. Chase 1987; D. Chase and A. Chase 1994). We include documentation for Caracol rulers being buried at Tikal in a forthcoming chapter in Forest of Kings Revisited (eds. T. Stanton and M. K. Brown) to be published by the University Press of Colorado. None of the research reported here would have been possible without the support of the Belize Institute of Archaeology (IOA; previously the Belize Department of Archaeology), the University of Central Florida, the assistance of project members and staff, and the various sponsors of the Caracol Archaeological Project. The research has been funded by the Ahau Foundation, the Alphawood Foundation, the Dart Foundation, the Foundation for the Advancement of Mesoamerican Studies Inc., the Geraldine and Emory Ford Foundation, the Government of Belize, the Harry Frank Guggenheim Foundation, the National Aeronautics and Space Agency, the National Science Foundation, the Stans Foundation, the United State Agency for International Development, the University of Central Florida, and private donations to the UCF Foundation, Inc. We also acknowledge the members of IHOPE-Maya for many hours of productive meetings since 2009 that have helped all of us collectively understand the multitude of ancient human-nature relationships that existed in the Maya region. Particular individuals who have been key in providing support in Belize include Jaime Awe, Melissa Badillo, David Griffin, Allan Moore, John Morris, George Thompson, Harriot Topsey, and Brian Woodye. Several project members have been multiple season veterans whose efforts greatly benefited the site and our sanity; chief among them are Maureen Carpenter, Lucas Martindale Johnson, Lisa Johnson, and Amy Morris. Our children-Adrian, Aubrey, and Elyse - also spent minimally the first 19 years of their lives on site at the excavations at Caracol. We also acknowledge the population of Belize, and particularly those of the Cayo District for their intense interest in understanding the Maya past. Finally, we thank Gary Feinman for inviting a summary of this long-term research for the journal, Linda Nicholas and Gary Feinman for constructive suggestions, Christophe Helmke for commenting on our epigraphic passages, and the seven reviewers of this paper for their helpful comments that have hopefully strengthened the final product.

Open Access This article is distributed under the terms of the Creative Commons Attribution 4.0 International License (http://creativecommons.org/licenses/by/4.0/), which permits unrestricted use, distribution, and reproduction in any medium, provided you give appropriate credit to the original author(s) and the source, provide a link to the Creative Commons license, and indicate if changes were made. 


\section{References Cited}

Aimers, J., and Hodell, D. A. (2011). Societal collapse: Drought and the Maya. Nature 479: 44-45.

Anderson, A. H. (1952). Archaeology in British Honduras today. Proceedings of the 30th International Congress of Americanists, Cambridge, pp. 32-35.

Anderson, A. H. (1958). Recent discoveries at Caracol Site, British Honduras. Proceedings of the 30th International Congress of Americanists, Copenhagen, pp. 494-499.

Anderson, A. H. (1959). More discoveries at Caracol, British Honduras. In Actas del 33rd Congreso Internacional des Americanistas, Vol. 2, Costa Rica, pp. 211-218.

Andrews, E. W., and Fash, W. L. (eds.) (2005). Copan: The History of an Ancient Maya Kingdom, School of American Research Press, Santa Fe, NM.

Arden, T. (ed.) (2002). Ancient Maya Women, AltaMira Press, Walnut Creek, CA.

Arkush, E. N. (2008). The Archaeology of Warfare: Prehistories of Raiding and Conquest, University Press of Florida, Gainesville.

Bair, D. A., and Terry, R. E. (2012). In search of markets and fields: Soil chemical investigations at Motul de San Jose. In Foias, A. E., and Emery, K. F. (eds.), Motul de San Jose: Politics, History, and Economy in a Classic Maya Polity, University Press of Florida, Gainesville, pp. 357-385.

Ballay, J. M. (1994). Emergence of an architectural style on Caana. In Chase, D. Z., and Chase, A. F. (eds.), Studies in the Archaeology of Caracol, Belize, Monograph 7, Pre-Columbian Art Research Institute, San Francisco, pp. 40-46.

Beach, T., Luzzadder-Beach, S., Dunning, N., Hageman, J., and Lohse, J. (2002). Upland agriculture in the Maya Lowlands: Ancient soil conservation in northwestern Belize. Geographical Review 92: 372-397.

Becker, M. (1973). Archaeological evidence for occupational specialization among the Classic period Maya at Tikal, Guatemala. American Antiquity 38: 396-406.

Becker, M. (2003). Plaza plans at Tikal: A research strategy for inferring social organization and processes of culture change at lowland Maya sites. In Sabloff, J. A. (ed.), Tikal: Dynasties, Foreigners, and Affairs of State: Advancing Maya Archaeology, School of American Research Press, Santa Fe, NM, pp. 253-280.

Becker, M. (2004). Maya heterarchy as inferred from Classic-period plaza plans. Ancient Mesoamerica 15: $127-138$.

Becker, M. (2015). Ancient Maya markets: Architectural grammar and market identifications. In King, E. (ed.), The Ancient Maya Marketplace: The Archaeology of Transient Space, University of Arizona Press, Tucson, pp. 90-110.

Beetz, C. (1980). Caracol thirty years later: A preliminary account of two rulers. Expedition 22(3): 4-11.

Beetz, C., and Satterthwaite, L. (1981). The Monuments and Inscription of Caracol, Belize, University Museum Monograph 45, University of Pennsylvania, Philadelphia.

Blanton, R. E., and Fargher, L. F. (2008). Collective Action in the Formation of Pre-Modern States, Springer, New York.

Brady, J. E., Ball, J. W., Bishop, R. L., and Pring, D. (1998). The lowland Maya "Protoclassic.” Ancient Mesoamerica 9: 17-38.

Braswell, G. E. (2003). The Maya and Teotihuacan: Reinterpreting Early Classic Interaction, University of Texas, Press, Austin.

Burgess, E. W. (1923). The growth of the city: An introduction to a research project. In Park, R. E., Burgess, E. W., and McKenzie, R. D. (eds), The City, University of Chicago Press, Chicago, pp. 47-62.

Callaghan, M. G. (2013). Politics through pottery: A view of the Preclassic-Classic transition from Building B, Group II, Holmul, Guatemala. Ancient Mesoamerica 24(2): 307-341.

Callaghan, M. G. (2014). Maya polychrome vessels as inalienable possessions. In Kovacevich, B., and Callaghan, M. G. (eds.), The Inalienable in the Archaeology of Mesoamerica, Wiley, Malden, MA, pp. 112-127.

Cap, B. (2015). How to know it when we see it: Marketplace identification at the Classic Maya site of Buenavista del Cayo, Belize. In King, E. (ed.), The Ancient Maya Marketplace: The Archaeology of Transient Space, University of Arizona Press, Tucson, pp. 111-137.

Carballo, D. M., Roscoe, P., and Feinman, G. M. (2014). Cooperation and collective action in the cultural evolution of complex societies. Journal of Archaeological Method and Theory 21: 98-133. 
Chase, A. F. (1985). Troubled times: The archaeology and iconography of the terminal Classic southern lowland Maya. In Robertson, M. G., and Fields, V. M. (eds.), Fifth Palenque Round Table, 1983, Vol. VII, Pre-Columbian Art Research Institute, San Francisco, pp. 103-114.

Chase, A. F. (1988). Jungle surveying: Mapping the archaeological site of Caracol, Belize. Point of Beginning (P.O.B.) 13(3): 10-24.

Chase, A. F. (1991). Cycles of time: Caracol in the Maya realm. In Robertson, M. G. (ed.), Sixth Palenque Round Table, 1986, Vol. VII, University of Oklahoma Press, Norman, pp. 32-42.

Chase, A. F. (1992). Elites and the changing organization of Classic Maya society. In Chase, D. Z., and Chase, A. F. (eds.), Mesoamerican Elites: An Archaeological Assessment, University of Oklahoma Press, Norman, pp. 30-49.

Chase, A. F. (1994). A contextual approach to the ceramics of Caracol, Belize. In Chase, D. Z., and Chase, A. F. (eds.), Studies in the Archaeology of Caracol, Belize, Monograph 7, Pre-Columbian Art Research Institute, San Francisco, pp. 157-182.

Chase, A. F. (1998). Planeación cívica e integración de sitio en Caracol, Belice: definiendo una economía administrada del periodo Clásico maya. Los Investigadores de la Cultura Maya 6(1): 26-44.

Chase, A. F., and Chase, D. Z. (1987). Investigations at the Classic Maya City of Caracol, Belize: 19851987, Monograph 3. Pre-Columbian Art Research Institute, San Francisco.

Chase, A. F., and Chase, D. Z. (1989). The investigation of Classic period Maya warfare at Caracol, Belize. Mayab 5: 5-18.

Chase, A. F., and Chase, D. Z. (1994). Details in the archaeology of Caracol, Belize: An introduction. In Chase, D. Z., and Chase, A. F. (eds.), Studies in the Archaeology of Caracol, Belize, Monograph 7 , Pre-Columbian Art Research Institute, San Francisco, pp. 1-11.

Chase, A. F., and Chase, D. Z. (1995). External impetus, internal synthesis, and standardization: E group assemblages and the crystallization of Classic Maya society in the Southern Lowlands. In Grube, N. (ed.), The Emergence of Lowland Maya Civilization: The Transition from the Preclassic to Early Classic, Acta Mesoamericana Vol. 8, Markt Schwaben Verlag A. Surwein, Germany, pp. 87-101.

Chase, A. F., and Chase, D. Z. (1996a). A mighty Maya nation: How Caracol built an empire by cultivating its 'middle class.' Archaeology 49(5): 66-72.

Chase, A. F., and Chase, D. Z. (1996b). More than kin and king: Centralized political organization among the ancient Maya. Current Anthropology 37: 803-810.

Chase, A. F., and Chase, D. Z. (1996c). The organization and composition of Classic lowland Maya society: The view from Caracol, Belize. In Robertson, M. G., Macri, M., and McHargue, J. (eds.), Eighth Palenque Round Table, 1993, Pre-Columbian Art Research Institute, San Francisco, pp. 213-222.

Chase, A. F., and Chase, D. Z. (1998a). Scale and intensity in Classic period Maya agriculture: Terracing and settlement at the 'garden city' of Caracol, Belize. Culture and Agriculture 20(2): 60-77.

Chase, A. F., and Chase, D. Z. (1998b). Late Classic Maya political structure, polity size, and warfare arenas. In Ciudad Ruiz, A., Fernández Marquínez, M. Y., García Campillo, J. M., Iglesias Ponce de León, M. J., Lacandena García-Gallo, A., and Sanz Castro, L. T. (eds.), Anatomía de una civilización: aproximaciones interdisciplinarias a la cultura maya, Sociedad Espanola de Estudios Mayas, Madrid, pp. 11-29.

Chase, A. F., and Chase, D. Z. (2001a). Ancient Maya causeways and site organization at Caracol, Belize. Ancient Mesoamerica 12: 273-281.

Chase, A. F., and Chase, D. Z. (2001b). The royal court of Caracol, Belize: Its palaces and people. In Inomata, T., and Houston, S. D. (eds.), Royal Courts of the Ancient Maya: Volume 2: Data and Case Studies, Westview Press, Boulder, CO, pp. 102-137.

Chase, A. F., and Chase, D. Z. (2004). Terminal Classic status-linked ceramics and the Maya "collapse:" De facto refuse at Caracol, Belize. In Demarest, A., Rice, P., and Rice, D. (eds.), The Terminal Classic in the Maya Lowlands: Collapse, Transition, and Transformation, University Press of Colorado, Boulder, pp. 342-366.

Chase, A. F., and Chase, D. Z. (2005). The early Classic period at Caracol, Belize: Transitions, complexity, and methodological issues in Maya archaeology. Research Reports in Belizean Archaeology 2: 17-38.

Chase, A. F., and Chase, D. Z. (2006). Before the boom: Caracol's Preclassic era. Research Reports in Belizean Archaeology 3: 41-67.

Chase, A. F., and Chase, D. Z. (2007a). Ancient Maya urban development: Insights from the archaeology of Caracol, Belize. Journal of Belizean Studies 29(2): 60-71. 
Chase, A. F., and Chase, D. Z. (2007b). 'This is the end:' Archaeological transitions and the terminal Classic period at Caracol, Belize. Research Reports in Belizean Archaeology 4: 13-27.

Chase, A. F., and Chase, D. Z. (2009). Symbolic egalitarianism and homogenized distributions in the archaeological record at Caracol, Belize: Method, theory, and complexity. Research Reports in Belizean Archaeology 6: 15-24.

Chase, A. F., and Chase, D. Z. (2010). The context of ritual: Examining the archaeological record at Caracol, Belize. Research Reports in Belizean Archaeology 7: 3-15.

Chase, A. F., and Chase, D. Z. (2011). Status and power: Caracol, Teotihuacan, and the early Classic Maya world. Research Reports in Belizean Archaeology 8: 3-18.

Chase, A. F., and Chase, D. Z. (2012). Belize red ceramics and their implications for trade and exchange in the eastern Maya Lowlands. Research Reports in Belizean Archaeology 9: 3-14.

Chase, A. F., and Chase, D. Z. (2013a). Temporal cycles in the archaeology of Maya residential groups from Caracol, Belize. Research Reports in Belizean Archaeology 10: 13-23.

Chase, A. F., and Chase, D. Z. (2013b). Interpreting form and context: Ceramic subcomplexes at Caracol, Nohmul, and Santa Rita Corozal, Belize. In Aimers, J. (ed.), Ancient Maya Pottery: Classification, Analysis, and Interpretation, University Press of Florida, Gainesville, pp. 46-73.

Chase, A. F., and Chase, D. Z. (2014). Houses, households, and residential groups at Caracol, Belize. Research Reports in Belizean Archaeology 11: 3-17.

Chase, A. F., and Chase, D. Z. (2015a). The domestic economy of Caracol, Belize: Articulating with the institutional economy in an ancient Maya urban setting. Research Reports in Belizean Archaeology 12: $15-23$.

Chase, A. F., and Chase, D. Z. (2015b). A new Terminal Classic carved altar from Caracol, Belize. Mexicon 37: 47-49.

Chase, A. F., and Chase, D. Z. (2016). The ancient Maya City: Anthropogenic landscapes, settlement archaeology, and Caracol, Belize. Research Reports in Belizean Archaeology 13: 3-14.

Chase, A. F., and Chase, D. Z. (2017). E groups and the rise of complexity in the southeastern Maya Lowlands. In Freidel, D., Chase, A. F., Dowd, A., and Murdock, J. (eds.), Maya E Groups: Calendars, Astronomy, and Urbanism in the Maya Lowlands, University Press of Florida, Gainesville (in press).

Chase, A. F., and Rice, P. M. (eds.) (1985). The Lowland Maya Postclassic, University of Texas Press, Austin.

Chase, A. F., Chase, D. Z., and Cobos, R. (2008a). Jeroglíficos y arqueología maya: colusión o colisión. Mayab 20: 5-21.

Chase, A. F., Chase, D. Z., and Smith, M. E. (2009). States and empires in ancient Mesoamerica. Ancient Mesoamerica 20: 175-182.

Chase, A. F., Chase, D. Z., and White, C. (2001). El paisaje urbano maya: la integración de los espacios construidos y la estructura social en Caracol, Belice. In Ciudad Ruiz, A., Iglesias Ponce de León, M. J., and Martínez, M. C. (eds.), Reconstruyendo la ciudad maya: el urbanismo en las sociedades antiguas, Sociedad Española de Estudios Mayas, Madrid, pp. 95-122.

Chase, A. F., Grube, N, and Chase, D. Z. (1991). Three Terminal Classic Monuments from Caracol, Belize, Research Reports on Ancient Maya Writing 36, Center for Maya Research, Washington, DC.

Chase, A. F., Chase, D. Z., Zorn, E., and Teeter, W. G. (2008b). Textiles and the Maya archaeological record: Gender, power, and status in Classic period Caracol, Belize. Ancient Mesoamerica 19: $127-142$.

Chase, A. F., Chase, D. Z., Fisher, C. T., Leisz, S. J., and Weishampel, J. F. (2012). Geospatial revolution and remote sensing LiDAR in Mesoamerican archaeology. Proceedings of the National Academy of Sciences USA 109: 12916-12921.

Chase, A. F., Chase, D. Z., Awe, J. J., Weishampel, J. F., Iannone, G., Moyes, H., Yaeger, J., Brown, M. K., Shrestha, R. L., Carter, W. E., and Fernández Díaz, J. (2014a). Ancient Maya regional settlement and inter-site analysis: The 2013 west-central Belize LiDAR survey. Remote Sensing 6: 8671-8695.

Chase, A. F., Chase, D. Z., Terry, R. E., Horlacher, J. M., and Chase, A. S. (2015). Markets among the ancient Maya: The case of Caracol, Belize. In King, E. (ed.), The Ancient Maya Marketplace: The Archaeology of Transient Space, University of Arizona Press, Tucson, pp. 226-250.

Chase, A. F., Chase, D. Z., Weishampel, J. F., Drake, J. B., Shrestha, R. L. Slatton, K. C., Awe, J. J., and Carter, W. E. (2011). Airborne LiDAR, archaeology, and the ancient Maya landscape at Caracol, Belize. Journal of Archaeological Science 38: 387-398.

Chase, A. F., Lucero, L. J., Scarborough, V. L., Chase, D. Z., Cobos, R., Dunning, N., Gunn, J. Fedick, S., Fialko, V., Hegmon, M., Iannone, G., Lentz, D. L., Liendo, R., Prufer, K., Sabloff, J. A., Tainter, J., 
Valdez, F., and van der Leeuw, S. (2014b). Tropical landscapes and the ancient Maya: Diversity in time and space. In Chase, A. F., and Scarborough, V. L. (eds.), The Resilience and Vulnerability of Ancient Landscapes: Transforming Maya Archaeology through IHOPE, AP3A Paper 24(1), American Anthropological Association, Arlington, VA, pp. 11-29.

Chase, A. S. (2012). Beyond elite control: Maya water management at the site of Caracol, Belize. Senior thesis, Departments of Archaeology and Computer Science, Harvard University, Cambridge, MA.

Chase, A. S. (2016a). Districting and urban services at Caracol, Belize: Intrasite boundaries in an evolving Maya cityscape. Research Reports in Belizean Archaeology 13: 15-28.

Chase, A. S. (2016b). Beyond elite control: Residential reservoirs at Caracol, Belize. WIREs Water 3: $885-897$.

Chase, A. S., and Weishampel, J. (2016). Using LiDAR and GIS to investigate water and soil management in the agricultural terracing at Caracol, Belize. Advances in Archaeological Practice 4: 357-370.

Chase, D. Z. (1981). The Maya Postclassic at Santa Rita Corozal. Archaeology 34(1): 25-33.

Chase, D. Z. (1985a). Between earth and sky: Idols, images, and Postclassic cosmology. In Robertson, M. G., and Fields, V. M. (eds.), Fifth Palenque Round Table, 1983, Vol. VII, Pre-Columbian Art Research Institute, San Francisco, pp. 223-233.

Chase, D. Z. (1985b). Ganned but not forgotten: Late Postclassic archaeology and ritual at Santa Rita Corozal, Belize. In Chase, A. F., and Rice, P. M. (eds.), The Lowland Maya Postclassic, University of Texas Press, Austin, pp. 104-125.

Chase, D. Z. (1988). Caches and censerwares: Meaning from Maya pottery. In Lackey, L., and Kolb, C. (eds.), A Pot for All Reasons: Ceramic Ecology Revisited, Laboratory of Anthropology, Temple University, Philadelphia, pp. 81-104.

Chase, D. Z. (1990). The invisible Maya: Population history and archaeology at Santa Rita Corozal. In Culbert, T. P., and Rice, D. S. (eds.), Prehistoric Population History in the Maya Lowlands, University of New Mexico Press, Albuquerque, pp. 199-213.

Chase, D. Z. (1994). Human osteology, pathology, and demography as represented in the burials of Caracol, Belize. In Chase, D. Z., and Chase, A. F. (eds.), Studies in the Archaeology of Caracol, Belize, Monograph 7, Pre-Columbian Art Research Institute, San Francisco, pp. 123-138.

Chase, D. Z. (1997). Southern lowland Maya archaeology and human skeletal remains: Interpretations from Caracol (Belize), Santa Rita Corozal (Belize), and Tayasal (Guatemala). In Whittington, S. C., and Reed, D. M. (eds.), Bones of the Maya: Studies of Ancient Skeletons, Smithsonian Institution Press, Washington, DC, pp. 15-27.

Chase, D. Z., and Chase, A. F. (1988). A Postclassic Perspective: Excavations at the Maya Site of Santa Rita Corozal, Belize, Monograph 4, Pre-Columbian Art Research Institute, San Francisco.

Chase, D. Z., and Chase, A. F. (eds.) (1992). Mesoamerican Elites: An Archaeological Assessment, University of Oklahoma Press, Norman.

Chase, D. Z., and Chase, A. F. (eds.) (1994). Studies in the Archaeology of Caracol, Belize, Monograph 7 , Pre-Columbian Art Research Institute, San Francisco.

Chase, D. Z., and Chase, A. F. (1996). Maya multiples: Individuals, entries, and tombs in Structure A34 of Caracol, Belize. Latin American Antiquity 7: 61-79.

Chase, D. Z., and Chase, A. F. (1998). The architectural context of caches, burials, and other ritual activities for the Classic period Maya (as reflected at Caracol, Belize). In Houston, S. D. (ed.), Function and Meaning in Classic Maya Architecture, Dumbarton Oaks, Washington, DC, pp. 299-332.

Chase, D. Z., and Chase, A. F. (2000). Inferences about abandonment: Maya household archaeology and Caracol, Belize. Mayab 13: 67-77.

Chase, D. Z., and Chase, A. F. (2002). Classic Maya warfare and settlement archaeology at Caracol, Belize. Estudios de Cultura Maya 22: 33-51.

Chase, D. Z., and Chase, A. F. (2003a). Texts and contexts in classic Maya warfare: A brief consideration of epigraphy and archaeology at Caracol, Belize. In Brown, M. K., and Stanton, T. (eds.), Ancient Mesoamerican Warfare, AltaMira Press, Walnut Creek, CA, pp. 171-188.

Chase, D. Z., and Chase, A. F. (2003b). Secular, sagrado y revisitado: la profanación, alteración y reconsagración de los antiguos entierros mayas. In Ciudad Ruiz, A., Ruz Sosa, M. J., and Iglesias Ponce de León, M. J. (eds.), Antropología de la eternidad: la muerte en la cultura maya, Publicación 7, Sociedad de los Estudios Mayas, Madrid, pp. 255-277. 
Chase, D. Z., and Chase, A. F. (2004a). Patrones de enterramiento y ciclos residenciales en Caracol, Belice. In Cobos, R. (ed.), Culto funerario en la sociedad maya: Memoria de la Cuarta Mesa Redonda de Palenque, Instituto Nacional de Antropología e Historia, Mexico, pp. 203-230.

Chase, D. Z., and Chase, A. F. (2004b). Archaeological perspectives on Classic Maya social organization from Caracol, Belize. Ancient Mesoamerica 15: 111-119.

Chase, D. Z., and Chase, A. F. (2006). Framing the Maya collapse: Continuity, discontinuity, method, and practice in the Classic to Postclassic southern Maya Lowlands. In Schwartz, G., and Nichols, J. (eds.), After Collapse: The Regeneration of Complex Societies, University of Arizona Press, Tucson, pp. $168-187$.

Chase, D. Z., and Chase, A. F. (2008). ¿Qué no nos cuentan los jeroglíficos? Arqueología e historia en Caracol, Belice. Mayab 20: 93-108.

Chase, D. Z., and Chase, A. F. (2011). Ghosts amid the ruins: Analyzing relationships between the living and the dead among the ancient Maya at Caracol, Belize. In Fitzsimmons, J., and Shimada, I. (eds.), Living with the Dead: Mortuary Ritual in Mesoamerica, University of Arizona Press, Tucson, pp. $78-101$.

Chase, D. Z., and Chase, A. F. (2014a). Ancient Maya markets and the economic integration of Caracol, Belize. Ancient Mesoamerica 25: 239-250.

Chase, D. Z., and Chase, A. F. (2014b). Path dependency in the rise and denouement of a Classic Maya city: The case of Caracol, Belize. In Chase, A. F., and Scarborough, V. L. (eds.), The Resilience and Vulnerability of Ancient Landscapes: Transforming Maya Archaeology through IHOPE, AP3A Paper 24(1), American Anthropological Association, Arlington, VA, pp. 142-154.

Chase, D. Z., Chase, A. F., and Haviland, W. A. (1990). The Classic Maya city: Reconsidering "the Mesoamerican urban tradition." American Anthropologist 92: 499-506.

Chase, D. Z., Chase, A. F., Awe, J. J., Walker, J. H., and Weishampel, J. F. (2011). Airborne LiDAR at Caracol, Belize and the interpretation of ancient Maya society and landscapes. Research Reports in Belizean Archaeology 8: 61-73.

Claassen, C., and Joyce, R. A. (eds.) (1997). Women in Prehistory: North America and Mesoamerica, Dumbarton Oaks, Washington, DC.

Cobos, R. (1994). Preliminary report on the archaeological mollusca and shell ornaments of Caracol, Belize. In Chase, D. Z., and Chase, A. F. (eds.), Studies in the Archaeology of Caracol, Belize, Monograph 7, Pre-Columbian Art Research Institute, San Francisco, pp. 139-147.

Coe, W. R. (1957). Environmental limitation on Maya culture: A re-examination. American Anthropologist 59: 328-335.

Coe, W. R. (1962). A summary of excavation and research at Tikal, Guatemala: 1956-1961. American Antiquity 27: 479-507.

Coe, W. R. (1965). Tikal, Guatemala, and emergent Maya civilization. Science 147: 1401-1419.

Coe, W. R. (1990). Excavations in the Great Plaza, North Terrace, and North Acropolis of Tikal, Tikal Report 14, University of Pennsylvania Museum, Philadelphia.

Coe, W. R., and Haviland, W. A. (1982). Introduction to the Archaeology of Tikal, Guatemala, Tikal Report 12, University of Pennsylvania Museum, Philadelphia.

Coggins, C. C. (1975). Painting and Drawing Styles at Tikal: An Historical and Iconographic Reconstruction, Ph.D. dissertation, Department of Anthropology, Harvard University, Cambridge, MA.

Cowgill, G. (2004). Origins and development of urbanism: Archaeological perspectives. Annual Review of Anthropology 33: 525-549.

Crandall, J. (2009). Water and the mountains: Maya water management at Caracol, Belize. M.A. thesis, Department of Anthropology, University of Central Florida, Orlando.

Culbert, T. P., and Rice, D. S. (eds.) (1990). Precolumbian Population History in the Maya Lowlands, University of New Mexico Press, Albuquerque.

Cunningham-Smith, P., Chase, A. F., and Chase, D. Z. (2014). Fish from afar: Marine use at Caracol, Belize. Research Reports in Belizean Archaeology 11: 43-53.

Dahlin, B. H. (1984). A colossus in Guatemala: The Preclassic city of El Mirador. Archaeology 37: $18-25$.

Dahlin, B. H., Bair, D., Beach, T., Moriarty, M, and Terry, R. (2010). The dirt on food ancient feasts and markets among the lowland Maya. In Staller, J. E., and Carrasco, M. D. (eds.), Interdisciplinary Approaches to Food, Culture, and Markets in Ancient Mesoamerica, Springer, New York, pp. 191-232. 
Dahlin, B. H., Beach, T., Luzzadder-Beach, S., Hixson, D. R., Hutson, S. R., Magnoni, A., Mansell, E., and Mazeau, D. E. (2005). Reconstructing agricultural self-sufficiency at Chunchucmil, Yucatan, Mexico. Ancient Mesoamerica 16: 229-247.

Dahlin, B. H., Jensen, C. T., Terry, R. E., Wright, D. R., and Beach, T. (2007). In search of an ancient Maya market. Latin American Antiquity 18: 363-384.

Demarest, A. A. (2004). Ancient Maya: The Rise and Fall of a Rainforest Civilization, Cambridge University Press, Cambridge.

Demarest, A. A. (2006). The Petexbatun Regional Archaeological Project: A Multidisciplinary Study of the Maya Collapse, Monograph 1, Institute of Mesoamerican Archaeology, Vanderbilt University Press, Nashville, TN.

Demarest, A. A. (2013). The collapse of the classic Maya kingdoms of the southwestern Peten: Implications for the end of Classic Maya civilization. In Arnauld, M. C., and Breton, A. (eds.), Millenary Maya Societies: Past Crises and Resilience, Mesoweb, San Francisco, pp. 22-48.

Diamond, J. (2005). Collapse: How Societies Choose to Fail or Succeed, Allen Lane, London.

Dunning, N., Beach, T., Farrell, P., and Luzzadder-Beach, S. (1998). Prehispanic agrosystems and adaptive regions in the Maya Lowlands. Culture and Agriculture 20: 87-101.

Ensor, B. E. (2013). Crafting Prehispanic Maya Kinship, University of Alabama Press, Tuscaloosa.

Evans, D. H., Pottier, C., Fletcher, R., Hensley, S., Tapley, I., Milne, A., and Barbetti, M. (2007). A comprehensive archaeological map of the world's largest preindustrial settlement complex at Angkor, Cambodia. Proceedings of the National Academy of Sciences USA 104: 14277-14282.

Evans, D. H., Fletcher, R. J., Pottier, C., Chevance, J., Soutif, D., Tan, B. S., Im, S., Ea, D, Tin, T, Kim, S., Cromarty, C., De Greef, S., Hanus, K., Baty, P., Kuszinger, R., Shimoda, I., and Boornazian, G. (2013). Uncovering archaeological landscapes at Angkor using Lidar. Proceedings of the National Academy of Sciences USA 110: 12595-12600.

Fash, W. L. (1994). Changing perspectives on Maya civilization. Annual Review of Anthropology 23: 181-208.

Fash, W. L. (2001). Scribes, Warriors, and Kings: the City of Copan and the Ancient Maya, revised ed., Thames and Hudson, London.

Fedick, S. L. (ed.) (1996). The Managed Mosaic: Ancient Maya Agriculture and Resource Use, University of Utah Press, Salt Lake City.

Feinman, G. M., and Garraty, C. P. (2010). Preindustrial markets and marketing: Archaeological perspectives. Annual Review of Anthropology 39: 167-191.

Fletcher, R. (1995). The Limits of Settlement Growth: A Theoretical Outline, Cambridge University Press, New York.

Fletcher, R. (2009). Low-density, agrarian-based urbanism: A comparative view. Insights 2: 2-19.

Fletcher, R. (2012). Low-density, agrarian-based urbanism: Scale, power, and ecology. In Smith, M. E. (ed.), The Comparative Archaeology of Complex Societies, Cambridge University Press, New York, pp. 285-320.

Foias, A. E. (2013). Ancient Maya Political Dynamics, University Press of Florida, Gainesville.

Foias, A. E., and Bishop, R. L. (1997). Changing ceramic production and exchange in the Petexbatun region, Guatemala: Reconsidering the Classic Maya collapse. Ancient Mesoamerica 8: 275-291.

Folan, W. J., Kintz, E. R., and Fletcher, L. A. (1983). Coba: A Maya Metropolis, Academic Press, New York.

Folan, W. J., Marcus, J., Pincemin, S., Carrasco, M., Fletcher, L. A., and Morales, A. (1995). Calakmul: New data from an ancient Maya capital in Campeche, Mexico. Latin American Antiquity 6: 310-334.

Fox, J. A., and Justeson, J. S. (1986). Classic Maya dynastic alliance and succession. In Spores, R. (ed.), Ethnohistory: Supplement to the Handbook of Middle American Indians, Vol. 4, University of Texas Press, Austin, pp. 7-34.

Fox, J., Cook, S., Chase, A. F., and Chase, D. Z. (1996). Questions of political and economic integration: Segmentary versus centralized states among the ancient Maya. Current Anthropology 37: 795-801.

Freidel, D. A. (1986). Maya warfare: An example of peer polity interaction. In Refrew, C., and Cherry, J. F. (eds.), Peer Polity Interaction and Socio-Political Change, Cambridge University Press, Cambridge, pp. 93-108.

Freidel, D. A., and Sabloff, J. A. (1984). Cozumel: Late Maya Settlement Patterns, Academic Press, Orlando, FL.

Fried, M. (1967). The Evolution of Political Society: An Essay in Political Anthropology, Random House, New York. 
Garraty, C. P., and Stark, B. L. (eds.) (2010). Archaeological Approaches to Market Exchange in Ancient Societies, University Press of Colorado, Boulder.

Garreau, J. (1991). The Edge City: Life on the New Frontier, Doubleday, New York.

Gifford, J. C. (1976). Prehistoric Pottery Analysis and the Ceramics of Barton Ramie in the Belize Valley, Memoir 18, Peabody Museum of Archaeology and Ethnology, Harvard University, Cambridge, MA.

Gill, R. B. (2000). The Great Maya Droughts: Water, Life and Death, University of New Mexico Press, Albuquerque.

Gonlin, N., and Lohse, J. C. (eds.) (2007). Commoner Ritual and Ideology in Ancient Mesoamerica, University Press of Colorado, Boulder.

Gottman, J. (1961). Megalopolis: The Urbanized Northeastern Seaboard of the United States, Twentieth Century Fund, New York.

Graham, E. (1987). Resource diversity in Belize and its implications for models of lowland trade. American Antiquity 52: 753-767.

Graham, E. (1999). Stone cities, green cities. In Bacus, E. A., and Lucero, L. J. (eds.), Complex Polities in the Ancient Tropical World, Archeological Papers Vol. 9, American Anthropological Association, Arlington, VA, pp. 186-194.

Grube, N. (1990). A Reference to Water-Lily Jaguar on Caracol Stela 16, Copan Note 68, Copan, Honduras.

Grube, N. (1994). Epigraphic research at Caracol, Belize. In Chase, D. Z., and Chase, A. F. (eds.), Studies in the Archaeology of Caracol, Belize, Monograph 7, Pre-Columbian Art Research Institute, San Francisco, pp. 83-123.

Hammond, N. (1985). The emergence of Maya civilization. Scientific American 255: 106-115.

Hassig, R. (1991). Roads, routes, and ties that bind. In Trombold, C. E. (ed.), Ancient Road Networks and Settlement Hierarchies in the New World, Cambridge University Press, Cambridge, pp. 17-27.

Hassig, R. (1992) War and Society in Ancient Mesoamerica, University of California Press, Berkeley.

Haug, G. H., Gunther, D., Peterson, L. C., Sigman, D. M., Hughen, K. A., and Aeschlimann, B. (2003). Climate and the collapse of Maya civilization. Science 299: 1731-1735.

Haviland, W. A. (1970). Tikal, Guatemala, and Mesoamerican urbanism. World Archaeology 2: 186-198.

Healy, P. F., Lambert, J. D., Arnason, J. T., and Hebda, R. J. (1983). Caracol, Belize: Evidence of ancient Maya agricultural terraces. Journal of Field Archaeology 10: 397-410.

Helmke, C., and Awe, J. J. (2012). Ancient Maya territorial organization of central Belize: Confluence of archaeological and epigraphic data. Contributions in New World Archaeology 4: 59-90.

Helmke, C., and Awe J. J. (2016a). Death becomes her: An analysis of panel 3, Xunantunich, Belize. The PARI Journal 16(4): 1-14.

Helmke, C., and Awe J. J. (2016b). Sharper than a serpent's tomb: A tale of the snake-head dynasty as recounted on Xunanatunich panel 4. The PARI Journal 17(2): 1-22.

Helmke, C., Kettunen, H., and Guenter, S. (2006). Comments on the hieroglyphic texts of the B-group ballcourt markers at Caracol, Belize. Wayeb Notes 23: 1-27.

Hirth, K. G. (1998). The distributional approach: A new way to identify marketplace exchange in the archaeological record. Current Anthropology 39: 451-476.

Hirth, K. G. (2009). Craft production in a central Mexican marketplace. Ancient Mesoamerica 20: 89-102.

Hirth, K. G., and Pillsbury, J. (2013). Merchants, markets, and exchange in the pre-Columbian world. In Hirth, K. G., and Pillsbury, J. (eds.), Merchants, Markets, and Exchange in the Pre-Columbian World, Dumbarton Oaks, Washington, DC, pp. 1-22.

Houston, S. D. (1983). Warfare between Naranjo and Ucanal. Contributions to Maya Hieroglyphic Decipherment 1: 31-39.

Houston, S. D. (1986). Problematic Emblem Glyphs: Examples from Altar de Sacrificios, El Chorro, Rio Azul, and Xultun, Research Reports on Ancient Maya Writing 3, Center for Maya Research, Washington, DC.

Houston, S. D. (1987). Appendix II: Notes on Caracol epigraphy and its significance. In Chase, A. F., and Chase, D. Z., Investigations at the Classic Maya City of Caracol, Belize: 1985-1987, Monograph 3, Pre-Columbian Art Research Institute, San Francisco, pp. 85-100.

Houston, S. D. (1991). Caracol Altar 21. In Fields, V. M. (ed.), Sixth Palenque Round Table, 1986, Vol. VIII, University of Oklahoma Press, Norman, pp. 38-42.

Hutson, S. R. (2016). The Ancient Urban Maya: Neighborhoods, Inequality, and Built Form, University Press of Florida, Gainesville. 
Hutson, S. R., Hixson, D. R., Magnoni, A., Mazeau, D., and Dahlin, B. H. (2008). Site and community at Chunchucmil and ancient Maya urban centers. Journal of Field Archaeology 33: 19-40.

Iannone, G. (2005). The rise and fall of an ancient Maya petty royal court. Latin American Antiquity 16: $26-44$.

Iannone, G., Chase, A. F., Chase, D. Z., Awe, J. J., Moyes, H., Brook, G., Polk, J., Webster, J., and Conolly, J. (2014). An archaeological consideration of long-term socio-ecological dynamics on the Vaca Plateau, Belize. In Iannone, G. (ed.), The Great Maya Droughts in Cultural Context: Case Studies in Resilience and Vulnerability, University Press of Colorado, Boulder, pp. 271-300.

Inomata, T. (2001). The power and ideology of artistic creation: Elite craft specialists in Classic Maya society. Current Anthropology 42: 321-349.

Inomata, T. (2003). War, destruction, and abandonment: The fall of the Classic Maya center of Aguateca, Guatemala. In Inomata, T., and Webb, R. W. (eds.), The Archaeology of Settlement Abandonment in Middle America, University of Utah Press, Salt Lake City, pp. 43-60.

Jaeger, S. E. (1987). Appendix III: The Conchita causeway and associated settlement: Investigating social integration. In Chase, A. F., and Chase, D. Z., Investigations at the Classic Maya City of Caracol, Belize: 1985-1987, Monograph 3, Pre-Columbian Art Research Institute, San Francisco, pp. 101-105.

Jaeger, S. E. (1991). Settlement Pattern Research at Caracol, Belize: The Social Organization in a Classic Period Maya Site, Ph.D. dissertation, Department of Anthropology, Southern Methodist University, Dallas.

Jaeger Liepins, S. E. (1994). The Conchita causeway settlement subprogram. In Chase, D. Z., and Chase, A. F. (eds.), Studies in the Archaeology of Caracol, Belize, Monograph 7, Pre-Columbian Art Research Institute, San Francisco, pp. 47-63.

Johnson, Lisa. M., Crandall, J. M., and Johnson, Lucas M. (2015a). From vision to cosmovision: Memory and the senses in the creation of Maya ritual space. Archaeological Review from Cambridge 30: $113-122$.

Johnson, Lucas M. (2008). Tools of a local economy: Standardization and function among small chert tools from Caracol, Belize. M.A. thesis, Department of Anthropology, University of Central Florida, Orlando.

Johnson, Lucas M. (2014). Standardized lithic technology and crafting at the 'Gateway Group' from Caracol, Belize: Implications for Maya household archaeology. Research Reports in Belizean Archaeology 11: 81-94.

Johnson, Lucas M. (2016) Toward an Itinerary of Stone: An Investigation of Obsidian from Caracol, Belize, Ph.D. Dissertation, Department of Anthropology, University of Florida, Gainesville.

Johnson, Lucas M., Carpenter, M., Chase, A. F., and Chase, D. Z. (2015b). Articulating with the broader economy: Chert pressure blade technology in a Caracol residential group. Research Reports in Belizean Archaeology 12: 77-87.

Jones, C. (2015). The marketplace at Tikal. In King, E. (ed.), The Ancient Maya Marketplace: The Archaeology of Transient Space, University of Arizona Press, Tucson, pp. 67-89.

Jones, C., and Satterthwaite, L. (1982). The Monuments and Inscriptions of Tikal: The Carved Monuments, Tikal Report 33A, University Museum, University of Pennsylvania, Philadelphia.

Joyce, R. A. (2000). Gender and Power in Prehispanic Mesoamerica, University of Texas Press, Austin. Joyce, R. A. (2001). Negotiating sex and gender in Classic Maya society. In Klein, C. F. (ed.), Gender in Pre-Hispanic America, Dumbarton Oaks, Washington, DC, pp. 109-141.

Keeley, L. H. (1997). War Before Civilization: The Myth of the Peaceful Savage, 2nd ed., Oxford University Press, Oxford.

Kennett, D. J., Breitenbach, S. F., Aquino, V. V., Asmerom, Y., Awe, J. J., Baldini, J. U., Bartlein, P., Culleton, B. J., Ebert, C., Jazwa, C., Macri, M. J., Marwan, N., Polyak, V., Prufer, K. M., Ridley, H. E., Sodemann, H., Winterhalder, B., and Haug, G. H. (2012). Development and disintegration of Maya political systems in response to climate change. Science 338: 788-791.

Kidder, A. V., Jennings, J., and Shook, E. M. (1946). Excavations at Kaminaljuyu, Guatemala, Publication 561, Carnegie Institution of Washington, Washington, DC.

Krejci, E., and Culbert, T. P. (1995). Preclassic and Classic burials and caches in the Maya Lowlands. In Grube, N. (ed.), The Emergence of Lowland Maya Civilization, Acta Mesoamericana Vol. 8, Berlin, pp. 103-116.

Kurjack, E. B. (1974). Prehistoric Lowland Maya Community and Social Organization: A Case Study at Dzibilchaltun, Yucatan, Mexico, Publication 38, Middle American Research Institute, Tulane University, New Orleans, LA. 
Lachniet, M. S. (2015). Are aragonite stalagmites reliable paleoclimate proxies? Tests for oxygen isotope time-series replication and equilibrium. GSA Bulletin 127: 1521-1533.

Laporte, J. P. (1996). El concepto de entidad segmentaria en la historia arqueológica del noroeste de las montañas mayas. Mayab 10: 25-32.

Laporte, J. P. (1998). Una perspectiva del desarrollo político prehispánico en el sureste de Petén, Guatemala. In Ciudad Ruiz, A., Fernández Marquínez, M. Y., García Campillo, J. M., Iglesias Ponce de León, M. J., Lacandena García-Gallo, A., and Sanz Castro, L. T. (eds.), Anatomía de una civilización:aproximaciones interdisciplinarias a la cultura maya, Sociedad Espanola de Estudios Mayas, Madrid, pp. 131-160.

Laporte, J. P. (2001). Dispersión y estructura de las ciudades del sureste de Petén, Guatemala. In Ciudad Ruiz, A., Iglesias Ponce de León, M. J., and Martínez, M. D. (eds.), Reconstruyendo la ciudad maya: el urbanismo en las sociedades antiguas, Sociedad Espanola de Estudios Mayas, Madrid, pp. 137-161.

Laporte, J. P., and Torres, C. R. (1987). Los señoríos del sureste de Petén. Mayab 3: 7-23.

Le Blanc, S., and Register, K. E. (2003). Constant Battles: The Myth of the Peaceful, Noble Savage, St. Martin's Press, New York.

LeCount, L. J., and Yaeger, J. (2010). Classic Maya Provincial Politics: Xunantunich and Its Hinterlands, University of Arizona Press, Tucson.

Lentz, D. L., Dunning, N. P., and Scarborough, V. L. (2015). Tikal: Paleoecology of an Ancient Maya City, Cambridge University Press, Cambridge.

Lohse, J. C., and Valdez, F. (2004). Ancient Maya Commoners, University of Texas Press, Austin.

Lomitola, L. M. (2012). Ritual use of the human form: A contextual analysis of 'Charlie Chaplin' figures in the Maya Lowlands. M.A. thesis, Department of Anthropology, University of Central Florida, Orlando.

Looper, M. G. (2002). Women-men (and men-women): Classic Maya rulers and the third gender. In Ardren, T. (ed.), Ancient Maya Women, AltaMira Press, Walnut Creek, CA, pp. 171-202.

Loten, H. S., and Pendergast, D. M. (1984). A Lexicon for Maya Architecture, Archaeology Monograph 8, Royal Ontario Museum, Toronto.

Lucero, L. J. (1999a). Water control and Maya politics in the southern Maya Lowlands. In Bacus, E. A., and Lucero, L. J. (eds), Complex Polities in the Ancient New World, American Anthropological Association, Arlington, VA, pp. 35-49.

Lucero, L. J. (1999b). Classic lowland Maya political organization: A review. Journal of World Prehistory 13: 211-263.

Lucero, L. J. (2006). Water and Ritual: The Rise and Fall of Classic Maya Rulers, University of Texas Press, Austin.

Marcus, J. (1992). Mesoamerican Writing Systems: Propaganda, Myth, and History in Four Ancient Civilizations, Princeton University Press, Princeton, NJ.

Martin, S. (2005). Caracol Altar 21 revisited: More data on Double Bird and Tikal's wars of the mid-sixth century. The PARI Journal 6(1): 1-9.

Martin, S., and Grube, N. (1995). Maya superstates. Archaeology 48(6): 41-46.

Martin, S., and Grube, N. (2000). Chronicle of Maya Kings and Queens: Deciphering the Dynasties of the Ancient Maya, Thames and Hudson, London.

Martin, S., and Grube, N. (2008). Chronicle of Maya Kings and Queens: Deciphering the Dynasties of the Ancient Maya, 2nd edition, Thames and Hudson, London.

Masson, M. A. (2002). Introduction. In Masson, M. A., and Freidel, D. A. (eds.), Ancient Maya Political Economies, AltaMira Press, Walnut Creek, CA, pp. 1-30.

Mathews, J., and Garber, J. (2004). Models of cosmic order: Physical expression of sacred space among the ancient Maya. Ancient Mesoamerica 15: 49-59.

Mathews, P. D. (1991). Classic Maya emblem glyphs. In Culbert, T. P. (ed.), Classic Maya Political History, Cambridge University Press, Cambridge, pp. 19-29.

Mayer, K. H. (1990). The Stelae and Inscriptions of Sacul, Guatemala, Sauerwein Von Flemming, Berlin.

McAnany, P. A. (2010). Ancestral Maya Economies in Archaeological Perspective, Cambridge University Press, New York.

McKillop, H. I. (2006). The Ancient Maya: New Perspectives, Norton, New York.

Meggers, B. J. (1954) Environmental limitation on the development of culture. American Anthropologist 56: $801-824$.

Mejia, H. E, (2002). El área al este de Machaquila y la cuenca del Río El Chilar, Poptun. Reporte No. 16, Atlas Arqueologico de Guatemala, Instituto de Antropologia e Historia (IDAEH), Guatemala. 
Moholy-Nagy, H. (1985). Social and ceremonial uses of marine molluscs at Tikal. In Pohl, M. (ed.), Prehistoric Lowland Maya Environment and Subsistence Economy, Papers No. 77, Peabody Museum of Archaeology and Ethnology, Harvard University, Cambridge, MA, pp. 147-158.

Moholy-Nagy, H. (1997). Middens, construction fill, and offerings: Evidence for the organization of Classic period craft production at Tikal, Guatemala. Journal of Field Archaeology 24: 293-313.

Moholy-Nagy, H. (2003). The hiatus at Tikal, Guatemala. Ancient Mesoamerica 14: 77-83.

Morris, J. (2004). Mountain cow sites: Survey, excavations, and interpretations. Research Reports in Belizean Archaeology 1: 129-153.

Morris, E. H., Charlot, J., and Morris, A. A. (1931). The Temple of the Warriors at Chichen Itza, Yucatan, Publication 406, Carnegie Institution of Washington, Washington, DC.

Moyes, H., Robinson, M., Voorhies, B., Kosakowsky, L., Arksey, M., Ray, E., and Hernández, S. (2015). Dreams of Las Cuevas: A location of high devotional expression of the Late Classic Maya. Research Reports in Belizean Archaeology 12: 239-249.

Murtha, T. (2002). Land and Labor: Maya Terraced Agriculture: An Investigation of the Settlement Economy and Intensive Agricultural Landscape of Caracol, Belize, Ph.D. dissertation, Department of Anthropology, Pennsylvania State University, State College.

Murtha, T. (2009). Land and Labor: Maya Terraced Agriculture: An Investigation of the Settlement Economy and Intensive Agricultural Landscape of Caracol, Belize, DM Verlag Dr. Muller, Saarbruckan, Germany.

Murtha, T. (2015). Negotiated landscapes: Comparative settlement ecology of Tikal and Caracol. In Marken, D., and Fitzpatrick, J. (eds.), Classic Maya Polities of the Southern Lowlands: Integration, Interaction, Dissolution, University Press of Colorado, Boulder, pp. 75-98.

Nichols, D. L. (2016). Teotihuacan. Journal of Archaeological Research 24: 1-74.

Nielsen, A. E., and Walker, W. H. (2014). Warfare in Cultural Context: Practice, Agency, and the Archaeology of Violence, University of Arizona Press, Tucson.

Otterbein, K. F. (1973). The anthropology of war. In Honigmann, J. (ed.), Handbook of Social and Cultural Anthropology, Rand McNally and Company, Chicago, pp. 923-958.

Otterbein, K. F. (2009). The Anthropology of War, Waveland Press, Long Grove, IL.

Pendergast, D. M., Chase, A. F., Chase, D. Z., Graham, E., and Hammond, N. (1995). One person's impact on archaeology. Latin American Antiquity 6: 291-292.

Pfeffer, J. (1994). Competitive Advantage Through People: Unleashing the Power of the Work Force, Harvard Business School Press, Cambridge, MA.

Pollock, H. E., Roys, R. L., Proskouriakoff, T., and Smith A. L. (1962). Mayapan, Yucatan, Mexico, Publication 619, Carnegie Institution of Washington, Washington, DC.

Pope, C. (1994). Preliminary analysis of small chert tools and related debitage at Caracol, Belize. In Chase, D. Z., and Chase, A. F. (eds.), Studies in the Archaeology of Caracol, Belize, Monograph 7 , Pre-Columbian Art Research Institute, San Francisco, pp. 148-156.

Pope, C. (1996). Small chert tools and the debitage from craft activity areas at the Maya site of Caracol, Belize. M.A. thesis, Department of Anthropology, University of Texas, Austin.

Puleston, D. E. (1974). Intersite areas in the vicinity of Tikal and Uaxactun. In Hammond, N. (ed.), Mesoamerican Archaeology: New Approaches, University of Texas Press, Austin, pp. 303-311.

Puleston, D. E. (1983). The Settlement Survey of Tikal, Tikal Report 13, University of Pennsylvania Museum, Philadelphia.

Price. T. D., Burton, J. H., Sharer, R. J., Buikstra, J. E., Wright, L. E., Traxler, L. P., and Miller, K. A. (2010). Kings and commoners at Copan: Isotopic evidence for origins and movement in the Classic Maya period. Journal of Anthropological Archaeology 29: 15-32.

Quezada, S. (1993). Pueblos y caciques yucatecos, 1550-1580, Colegio de Mexico, Mexico.

Quezada, S. (2014). Maya Lords and Lordship: The Formation of Colonial Society in Yucatan, 13501600, University of Oklahoma Press, Norman.

Reents-Budet, D. (1994). Painting the Maya Universe: Royal Ceramics of the Classic Period, Duke University Press, Durham, NC.

Restall, M. (1997). The Maya World: Yucatec Culture and Society, 1550-1850, Stanford University Press, Stanford, CA.

Rice, P. M. (1978). Ceramic continuity and change in the Valley of Guatemala. In Wetherington, R. K. (ed.), The Ceramics of Kaminaljuyu, Guatemala, Pennsylvania State University Press, State College, pp. 511-542.

Rice, P. M. (1999). Rethinking Classic lowland Maya pottery censers. Ancient Mesoamerica 10: 25-50. 
Rice, P. M. (2004). Maya Political Science: Time, Astronomy, and the Cosmos, University of Texas Press, Austin.

Rice, P. M. (2013). Texts and the cities: Modeling Maya political organization. Current Anthropology 54: 684-715.

Rich, S. (2003). An analysis of a female Protoclassic costume from the site of Caracol, Belize. M.A. thesis, Department of Anthropology, University of Central Florida, Orlando.

Ricketson, O. G., and Ricketson, E. B. (1937). Uaxactun, Guatemala, Group E, 1926-1931, Publication 477, Carnegie Institution of Washington, Washington, DC.

Riese, B. (1984). Kriegsberichte der klassichen Maya. Baessler-Archiv, Beitrge zur Vlkerkunde 30: 255-321.

Rochette, E. T. (2014). Out of control? Rethinking assumptions about wealth goods production and the Classic Maya. Ancient Mesoamerica 25: 165-185.

Rothchild, N. A. (2006). Colonial and postcolonial New York: Issues of size, scale, and structure. In Storey, G. R. (ed.), Urbanism in the Preindustrial World: Cross-Cultural Approaches, University of Alabama Press, Tuscaloosa, pp. 121-136.

Sabloff, J. A. (1975). Excavations at Seibal, Department of Peten, Guatemala: Ceramics, Memoirs 13(2), Peabody Museum of Archaeology and Ethnology, Harvard University, Cambridge, MA.

Sabloff, J. A. (ed.) (2003). Tikal: Dynasties, Foreigners, and Affairs of State, School of American Research Press, Santa Fe, NM.

Sabloff, J. A., and Andrews, E. W. (eds.) (1986). Late Lowland Maya Civilization: Classic to Postclassic, University of New Mexico Press, Albuquerque.

Sabloff, J. A., and Rathje, W. R. (eds.) (1975). A Study of Changing Pre-Columbian Commercial Systems, Monograph 3, Peabody Museum of Archaeology and Ethnography, Harvard University, Cambridge, MA.

Sanders, W. T. (1973) The cultural ecology of the lowland Maya: A reevaluation. In Culbert, T. P. (ed.), The Classic Maya Collapse, University of New Mexico Press, Albuquerque, pp. 325-365.

Sanders, W. T., and Webster, D. (1988). The Mesoamerican urban tradition. American Anthropologist 90: 521-546.

Satterthwaite, L. (1951). Reconnaissance in British Honduras. University Museum Bulletin 16: 21-37.

Satterhwaite, L. (1954). Sculptured monuments from Caracol, British Honduras. University Museum Bulletin 18: $1-45$.

Savage, C. T. (2007). Alternative epigraphic interpretations of the Maya snake emblem glyph. M.A. thesis, Department of Anthropology, University of Central Florida, Orlando.

Scarborough, V. L., Chase, A. F., and Chase, D. Z. (2012a). Low density urbanism, sustainability, and IHOPE-Maya: Can the past provide more than history? UGEC Viewpoints 8: 20-24.

Scarborough, V. L., Dunning, N. P., Tankersley, K. B., Carr, C., Weaver, E., Grazioso, L., Lane, B., Jones, J. G., Buttles, P., and Valdez, F. (2012b). Water and sustainable land use at the ancient tropical city of Tikal, Guatemala. Proceedings of the National Academy of Sciences USA 109: $12408-12413$.

Scarborough, V. L., and Gallopin, G. G. (1991). A water storage adaptation in the Maya Lowlands. Science 251: 658-662.

Schele, L., and Freidel, D. A. (1990). A Forest of Kings, William Morrow, New York.

Scherer, A. K. (2015). Mortuary Landscapes of the Classic Maya: Rituals of Body and Soul, University of Texas Press, Austin.

Sharer, R. J. (1978). Archaeology and history at Quirigua, Guatemala. Journal of Field Archaeology 5: $51-70$.

Sharer, R. J. (1990). Quirigua: A Classic Maya Center and Its Sculptures, Carolina Academic Press, Durham, NC.

Sharer, R. J., and Sedat, D. W. (1987). Archaeological Investigations in the Northern Maya Highlands, Guatemala: Interaction and the Development of Maya Civilization, Monograph 59, University of Pennsylvania Museum, Philadelphia.

Sharer, R. J., and Traxler, L. (2006). The Ancient Maya, 6th ed., Stanford University Press, Stanford, CA.

Smith, A. L. (1950). Uaxactun, Guatemala: Excavations of 1931-1937, Publication 588, Carnegie Institution of Washington, Washington, DC.

Smith, M. E. (1987). Household possessions and wealth in agrarian states: Implications for archaeology. Journal of Anthropological Archaeology 6: 297-355.

Smith, M. E. (1989). Cities, towns, and urbanism: Response to Sanders and Webster. American Anthropologist 91: 454-460. 
Smith, M. E. (2007). Form and meaning in the earliest cities: A new approach to ancient urban planning. Journal of Planning History 6: 3-47.

Smith, M. E. (2010a). Sprawl, squatters, and sustainable cities: Can archaeological data shed light on modern urban issues? Cambridge Archaeological Journal 20: 229-253.

Smith, M. E. (2010b). The archaeological study of neighborhoods and districts. Journal of Anthropological Archaeology 29: 137-154.

Smith, M. E. (2011). Empirical urban theory for archaeologists. Journal of Archaeological Method and Theory 18: 167-192.

Smith, M. E. (2014). The Aztecs paid taxes, not tribute. Mexicon 36: 19-22.

Smith, M. E., and Novic, J. (2012). Introduction: Neighborhoods and districts in ancient Mesoamerica. In Arnauld, M. C., Manzanilla, L. R., and Smith, M. E, (eds.), The Neighborhood as a Social and Spatial Unit in Mesoamerican Cities. University of Arizona Press, Tucson, pp. 1-26.

Smith, R. E. (1955). Ceramic Sequence at Uaxactun, Guatemala, Publication 20, Middle American Research Institute, Tulane University, New Orleans, LA.

Smith, R. E. (1971). The Pottery of Mayapan including Studies of Ceramic Material from Uxmal, Kabah, and Chichen Itza, Papers No. 66, Peabody Museum of Archaeology and Ethnology, Harvard University, Cambridge, MA.

Soza, J., and Reents, D. (1980). Glyphic evidence for Classic Maya militarism. Belize Studies 8(3): 2-11.

Stone, A., Reents, D., and Coffman, R. (1985). Genealogical documentation of the Middle Classic dynasty of Caracol, El Cayo, Belize. In Robertson, M. G., and Benson, E. (eds.), Fourth Palenque Round Table 1980, Pre-Columbian Art Research Institute, San Francisco, pp. 267-275.

Storey, G. R. (2006). Introduction: Urban demography of the past. In Storey G. R. (ed.), Urbanism in the Preindustrial World: Cross-Cultural Approaches, University of Alabama Press, Tuscaloosa, pp. 1-23.

Storey, R. (1992). Life and Death in the Ancient City of Teotihuacan: A Modern Paleodemographic Synthesis, University of Alabama Press, Tuscaloosa.

Storey, R. (2006). Mortality through time in an impoverished residence of the Precolumbian city of Teotihuacan. In Storey, G. R. (ed.), Urbanism in the Preindustrial World: Cross-Cultural Approaches, University of Alabama Press, Tuscaloosa, pp. 277-294.

Stuart, D. (1998). 'The fire enters his house': Architecture and ritual in Classic Maya texts. In Houston, S. D. (ed.), Function and meaning in Classic Maya Architecture, Dumbarton Oaks, Washington, DC, pp. $373-426$.

Stuart, D. (2000). The arrival of strangers: Teotihuacan and Tollan in Classic Maya history. In Carrasco, D., Jones, L., and Sessions, S. (eds), Mesoamerica's Classic Heritage: From Teotihuacan to the Aztecs, University Press of Colorado, Boulder, pp. 465-513.

Stuart, D. (2005). The Inscriptions from Temple XIX at Palenque: A Commentary, Pre-Columbian Art Research Institute, San Francisco.

Stuart, D. (2007). The origin of Copan's founder: Maya decipherment: Ideas on ancient Maya writing and iconography, blog entry June 25, 2007 (accessed 9/22/15).

Stuart, D., and Houston, S. (1994). Classic Maya Place Names, Studies in Pre-Columbian Art and Archaeology 33, Dumbarton Oaks, Washington, DC.

Taylor, W. W. (1948). A Study of Archaeology, Memoir 69, American Anthropological Association, Washington, DC.

Teeter, W. G. (2001). Maya Diet in a Changing Urban Environment: Faunal Utilization at Caracol, Belize, Ph.D. dissertation, Department of Anthropology, University of California, Los Angeles.

Teeter, W. G., and Chase, A. F. (2004). Adding flesh to bones: Using zooarchaeology research to answer the big-picture questions. Archaeofauna 13: 155-172.

Terry, R. E., Bair, D. A., and Coronel, E. G. (2015). Soil chemistry in the search for ancient Maya marketplaces. In King, E. (ed.), The Ancient Maya Marketplace: The Archaeology of Transient Space, University of Arizona, Press, Tucson, pp. 138-167.

Thompson, J. E. (1931). Archaeological Investigations in the Southern Cayo District, British Honduras, Publication 301, Field Museum of Natural History, Chicago.

Tiesler, V. (1999). Rasgos bioculturales entre los antiguos mayas: aspectos arqueológicos y sociales, Ph.D. dissertation, Department of Anthropology, Escuela Nacional de Antropología e Historia, Mexico.

Tiesler, V. (2014). The Bioarchaeology of Artificial Cranial Modifications: New Approaches to Head Shaping and Its Meanings in Pre-Columbian Mesoamerica and Beyond, Springer, New York. 
Tiesler, V., and Cucina, A. (2006). Janaab' Pakal of Pelenque: Reconstructing the Life and Death of a Maya Ruler, University of Arizona Press, Tucson.

Tourtellot, G. (1988). Excavations at Seibal: Peripheral Survey and Excavation, Settlement and Community Patterns, Memoir 16, Peabody Museum of Archaeology and Ethnology, Harvard University Press, Cambridge, MA.

Toscano, S. (1944).Arte precolombino de México y de la América Central, Universidad Nacional Autónoma de México, Mexico.

Tozzer, A. M. (1957). Chichen Itza and Its Cenote of Sacrifice, Memoirs 11 and 12, Peabody Museum of Archaeology and Ethnology, Harvard University, Cambridge, MA.

Trombold, C. D. (1991). Ancient road Networks and Settlement Hierarchies in the New World, Cambridge University Press, Cambridge.

Turner, B. L., and Sabloff J. A. (2012). Classic period collapse of the central Maya Lowlands: Insights about human-environment relationships for sustainability. Proceedings of the National Academy of Sciences USA 109: 13908-13914.

Valdes, J. A., and Fahsen, F. (1995). The reigning dynasty of Uaxactun during the Early Classic: The rulers and the ruled. Ancient Mesoamerica 6: 197-220.

Wetherington, R. K. (ed.) (1978). The Ceramics of Kaminaljuyu, Guatemala, Pennsylvania State University Press, State College.

Webster, D. (1976). Defensive Earthworks at Becan, Campeche, Mexico, Middle American Research Institute Publication 41, Tulane University Press, New Orleans.

Webster, D. (2000). The not so peaceful civilization: A review of Maya warfare. Journal of World Prehistory 14: 65-119.

Weeks, J. M., Hill, J. A., and Golden, C. W. (2005). Piedras Negras Archaeology, 1931-1939, Museum of Archaeology and Anthropology, University of Pennsylvania, Philadelphia.

Weiss-Krejci, E., and Sabbas, T. (2002). The potential role of small depressions as water storage features in the central Maya Lowlands. Latin American Antiquity 13: 343-357.

Williams, J. S., and White, C. D. (2006). Dental modification in the Postclassic population from Lamanai, Belize. Ancient Mesoamerica 17: 139-151.

Willey, G. R. (1973). General Summary and Conclusions: The Altar de Sacrificios Excavations, Papers 64(3), Peabody Museum of Archaeology and Ethnology, Harvard University, Cambridge, MA.

Willey, G. R. (1990). General summary and conclusions. In Willey, G. (ed.), Excavations at Seibal, Department of Peten, Guatemala, Memoirs 17(4), Peabody Museum of Archaeology and Ethnology, Harvard University, Cambridge, MA, pp. 175-276.

Willey, G. R., Bullard, W. R., Glass, J. B., and Gifford, J. C. (1965). Prehistoric Maya Settlements in the Belize Valley, Papers 54, Peabody Museum of Archaeology and Ethnology, Harvard University, Cambridge, MA.

Yaeger, J., and Hodell, D. A. (2008). The collapse of Maya civilization: Assessing the interaction of culture, climate, and environment. In Sandweiss, D. H., and Quilter, J. (eds.), El Nino, Catastrophism, and Culture Change in Ancient America, Dumbarton Oaks, Washington, DC, pp. 197-251.

\section{Bibliography of Recent Literature}

Aimers, J. J. (2013). Ancient Maya Pottery: Classification, Analysis, and Interpretation, University Press of Florida, Gainesville.

Andrieu, C., Rodas, E., and Luin, L. (2014). The values of Classic Maya jade: A reanalysis of Cancuen's jade workshop. Ancient Mesoamerica 25: 141-164.

Ardren, T. (2015). Social Identities in the Classic Maya Northern Lowlands, University of Texas Press, Austin.

Ashmore W. (2015). Contingent acts of remembrance: Royal ancestors of Classic Maya Copan and Quirigua. Ancient Mesoamerica 26: 213-231.

Awe, J. J. (2013). Journey on the Cahal Pech time machine: An archaeological reconstruction of the dynastic sequence at a Belize Valley polity. Research Reports in Belizean Archaeology 5: 159-174.

Bishop, R. L., and Blackman, M. J. (2002). Instrumental neutron activation analysis of archaeological ceramics: Scale and interpretation. Accounts of Chemical Research 35: 603-610.

Braswell, G. E. (ed.) (2012). The Ancient Maya of Mexico: Reinterpreting the Past of the Northern Maya Lowlands, Acumen, Durham, NC. 
Canuto, M. A., and Bell, E. E. (2013). Archaeological investigations in the El Paraiso Valley: The role of secondary centers in the multiethnic landscape of Classic period Copan. Ancient Mesoamerica 24: $1-24$.

Carballo D. M., and Fortenberry B. (2015). Bridging prehistory and history in archaeology of cities. Journal of Field Archaeology 40: 542-559.

Chase, A. F., and Chase, D. Z. (2004). Exploring ancient economic relationships at Caracol, Belize. Research Reports in Belizean Archaeology 1: 115-127.

Chase, A. F., and Chase, D. Z. (2005). Contextualizing the collapse: Hegemony and terminal Classic ceramics from Caracol, Belize. In Lopez Varella, S., and Foias, A. (eds.), Geographies of Power: Understanding the Nature of Terminal Classic Pottery in the Maya Lowlands, BAR Monograph S1447, Archaeopress, Oxford, pp. 73-91.

Chase, A. F., and Chase, D. Z. (2006). En medio de la nada, en el centro del universo: perspectivas sobre el desarrollo de las ciudades mayas. In Iglesias Ponce de León, M. J., Valencia Rivera, R., and Ciudad Ruiz, A. (eds.), Nuevas ciudades, nuevas patrias: fundación y relocalización de ciudades en Mesoamérica y el Mediterraneo antiguo, S.E.E.M., Madrid, pp. 39-64.

Chase, A. F., and Chase, D. Z. (2008). Methodological issues in the archaeological identification of the Terminal Classic and Postclassic transition in the Maya area. Research Reports in Belizean Archaeology 5: 23-36.

Chase, A. F., and Chase, D. Z. (2016). Detection of Maya ruins by LiDAR: Applications, case study, and issues. In Masini, N., and Soldovieri, F. (eds.), Sensing the Past: Geoscience and Sensing Technologies for Cultural Heritage, Springer, New York (in press).

Chase, A. F., and Chase, D.Z. (2016). Urbanism and anthropogenic landscapes. Annual Review of Anthropology 45 DOI: 10.1146/annurev-anthro-102215-095852.

Chase, A. F., Chase, D. Z., Awe, J. J., Weishampel, J. F., Iannone, G., Moyes, H., Yaeger, J., and Brown, M. K. (2014). The use of LiDAR in understanding the ancient Maya landscape: Caracol and western Belize. Advances in Archaeological Practice 2: 208-221.

Chase, A. F., Reese-Taylor, K., Fernández-Díaz, J. C., and Chase, D. Z. (2016). Progression and issues in the Mesoamerican geospatial revolution: An introduction. Advances in Archaeological Practice 4: 219-231.

Chase, A. F., and Scarborough V. L. (eds.) (2014). The Resilience and Vulnerability of Ancient Landscapes: Transforming Maya Archaeology through IHOPE, Archeological Papers No. 24, American Anthropological Association, Arlington VA.

Chase, A. S., and Chase, A. M. (2015). Ceramic standardization and the domestic economy of the ancient Maya: Belize red tripod plates at Caracol, Belize. Research Reports in Belizean Archaeology 12: $65-76$.

Chase, A. S., Chase, D. Z., and Chase, A. F. (2016). LiDAR for archaeological research and the study of historical landscapes. In Masini, N., and Soldovieri, F. (eds.), Sensing the Past: Geoscience and Sensing Technologies for Cultural Heritage, Springer, New York (in press).

Chase, D. Z., and Chase, A. F. (2015). Thirty years of archaeology at Caracol, Belize: retrospective and prospective. Research Reports in Belizean Archaeology 12: 3-14.

Chinchilla Mazariegos, O., Tiesler, V., Gomez, O., and Price, T. D. (2015). Myth, ritual and human sacrifice in Early Classic Mesoamerica: Interpreting a cremated double burial from Tikal, Guatemala. Cambridge Archaeological Journal 25: 187-210.

Coe, M. D. (2006). Final Report: An Archaeologist Excavates his Past, Thames and Hudson, New York.

Demarest, A. A., Andrieu, C., Torres, P. Forne, M, Barrientos, T., and Wolf, M. (2014). Economy, exchange, and power: New evidence from the Late Classic Maya port city of Cancuen. Ancient Mesoamerica 25: 187-219.

Demarest, A. A., Rice, P., and Rice, D. (eds.) (2004). The Terminal Classic in the Maya Lowlands: Collapse, Transition, and Transformation, University Press of Colorado, Boulder.

Dowd, A. S., and Milbrath, S. (eds.) (2015). Cosmology, Calendars, and Horizon-Based Astronomy in Ancient Mesoamerica, University Press of Colorado, Boulder.

Doyle, J. A. (2012). Regroup on "E groups": Monumentality and early centers in the Middle Preclassic Maya Lowlands. Latin American Antiquity 23: 355-379.

Dunning, N. P., and Beach, T. P. (2010). Farms and forests: Spatial and temporal perspectives on ancient Maya landscapes. In Martini, I. P., and Chesworth, W. (eds.), Landscapes and Societies, Springer, New York, pp. 369-389.

Dunning, N. P., Beach, T. P., and Luzzadder-Beach, S. (2012). Kax and Kol: Collapse and resilience in lowland Maya civilization. Proceedings of the National Academy of Sciences USA 109:3652-3657. 
Ebert, C. E., Hoggarth, J. A., and Awe, J. J. (2016). Integrating quantitative Lidar analysis and settlement survey in the Belize River valley. Advances in Archaeological Practice 4: 284-300.

Ebert C. E., Prufer K. M., Macri M. J., Winterhalder B., and Kennett D. J. (2014). Terminal long count dates and the disintegration of Classic period Maya polities. Ancient Mesoamerica 25: 337-356.

Estrada-Belli, F. (2011). The First Maya Civilization: Ritual and Power before the Classic Period, Routledge, New York.

Fisher C. (2014). The role of infield agriculture in Maya cities. Journal of Anthropological Archaeology 36: 196-210.

Freidel, D. A., Chase, A. F., Dowd, A., and Murdock, J. (eds.) (2017). Maya E Groups: Calendars, Astronomy, and Urbanism in the Maya Lowlands, University Press of Florida, Gainesville (in press).

Foias, A. E., and Emery, K. F. (eds.) (2012). Motul de San Jose: Politics, History, and Economy in a Classic Maya Polity, University Press of Florida, Gainesville.

Garber, J. F. (ed.) (2004). The Ancient Maya of the Belize Valley: Half a Century of Archaeological Research, University Press of Florida, Gainesville.

Graham, E. (2011). Maya Christians and Their Churches in Sixteenth Century Belize, University Press of Florida, Gainesville.

Halperin, C. T. (2014). Ruins in pre-Columbian Maya urban landscapes. Cambridge Archaeological Journal 24: 321-344.

Halperin, C. T., Bishop, R. L., Spensley, E., and Blackman, M. J. (2009). Late Classic (AD 600-900) Maya market exchange: Analysis of figurines from the Motul de San Jose region, Guatemala. Journal of Field Archaeology 34: 457-480.

Hare, T., Masson, M., and Russel, B. (2014). High-density LiDAR mapping of the ancient city of Mayapan. Remote Sensing 6: 9064-9085.

Harrison-Beck, E. (ed.) (2012). Power and Identity in Archaeological Theory and Practice: Case Studies from Ancient Mesoamerica, University of Utah Press, Salt Lake City.

Hightower J. N., Butterfield A. C., and Weishampel J. F. (2014). Quantifying ancient Maya land use legacy effects on contemporary rainforest canopy structure. Remote Sensing 6: 10716-10732.

Hoggarth, J. A., Breitenbach, S. F., Culleton, B. J., Ebert, C. E., Masson, M. A., and Kennett, D. J. (2016). The political collapse of Chichen Itza in climatic and cultural context. Global and Planetary Change 138: $25-42$.

Houk, B. A. (2015). Ancient Maya Cities of the Eastern Lowlands, University Press of Florida, Gainesville.

Houston, S. D. (2014). The Life Within: Classic Maya and the Matter of Permanence, Yale University Press, New Haven, CT.

Houston, S. D., Newman, S., Roman, E., Garrison, T, Carter, N, de Carteret, A., Scherer, A, and Taube, K. (2015). Temple of the Night Sun: A Royal Maya Tomb at El Diablo, Guatemala, Precolumbia Mesoweb Press, San Francisco.

Hruby, Z., Braswell, G. E., and Chinchilla, O. (eds.) (2010). The Technology of Maya Civilization: Political Economy and Beyond, Equinox, London.

Hutson, S., Kidder, B., Lamb, C., Vallejo-Caliz, D., and Welch, J. (2016). Small buildings and small budgets: Making Lidar work in northern Yucatan. Advances in Archaeological Practice 4: 268-283.

Hutson, S. R., and Welch, J. A. (2014). Sacred landscapes and building practices at Uci, Kancab, and Ucanha, Yucatan, Mexico. Ancient Mesoamerica 25: 421-439.

Iannone, G. (ed.) (2014). The Great Maya Droughts in Cultural Context, University Press of Colorado, Boulder.

Iannone, G., Houk, B. A., and Schwake, S. A. (eds.) (2016), Ritual, Violence, and the Fall of the Classic Maya Kings, University Press of Florida, Gainesville.

Isendahl C., and Smith M. E. (2013). Sustainable Agrarian urbanism: The low-density cities of the Mayas and Aztecs. Cities 31: 132-143.

Jackson, S. E. (2013). Politics of the Maya Court: Hierarchy and Change in the Late Classic Period, University of Oklahoma Press, Norman.

Jackson, S. E. (2016). Envisioning artifacts: A Classic Maya view of the archaeological record. Journal of Archaeological Method and Theory, published online: 14 March 2016. DOI 10.1007/s10816-0169278-7.

Johnson, S. A. (2015). The roots of Sotuta: Dzitas slate as a Yucatecan tradition. Ancient Mesoamerica 26: $113-126$.

Kovacevich, B., and Callaghan, M. (eds.) (2013). The Inalienable in the Archaeology of Mesoamerica, Archeological Papers No. 23, American Anthropological Association, Arlington, VA. 
Landau, K. (2015). Spatial logic and Maya city planning: The case for cosmology. Cambridge Archaeological Journal 25: 275-292.

LeCount, L. J., Wells, E. C., Jamison, T. R., and Mixter, D. W. (2016). Geochemical characterization of inorganic residues on plaster floors from a Maya palace complex at Actuncan, Belize. Journal of Archaeological Science: Reports 5: 453-454.

Lemonnier, E., and Vanniere, B. (2013). Agrarian features, farmsteads, and homesteads in the Río Bec nuclear zone, Mexico. Ancient Mesoamerica 24: 397-413.

Loughlin, M. L., Pool, C. A., Fernández-Díaz, J. C., and Shrestha, R. L. (2016). Mapping the Tres Zapotes polity: The effectiveness of Lidar in tropical alluvial settings. Advances in Archaeological Practice 4: 301-313.

Lucero L. J., Fletcher R., and Coningham R. (2015). From 'Collapse' to urban diaspora: The transformation of low-density dispersed Agrarian urbanism. Antiquity 89:1139-1154.

Macrae, S., and Iannone, G. (2016). Understanding ancient Maya agricultural systems through Lidar and hydrological mapping. Advances in Archaeological Practice 4: 371-392.

McKillop, H. (2002). Salt: White Gold of the Ancient Maya, University Press of Florida, Gainesville.

McNeil, C. (ed.) (2009). Chocolate in Mesoamerica: A Cultural History of Cacao, University Press of Florida, Gainesville.

Magnoni, A., Stanton, T. W., Barth, N., Fernández-Díaz, J. C., León, J. F., Ruiz, F. P., and Wheeler, J. A. (2016). Assessing detection thresholds of archaeological features in airborne Lidar data from central Yucatan. Advances in Archaeological Practice 4: 232-248.

Marcus J., and Sabloff J. A. (eds.) (2008). The Ancient City: New Perspectives on Urbanism in the Old and New World, School for Advanced Research Press, Santa Fe, NM.

Mathews, J. P., and Shaw, J. W. (eds.) (2005). Quintana Roo Archaeology, University of Arizona Press, Tucson.

Miller, M., and Brittenham, C. (2013). The Spectacle of the Late Maya Court: Reflections on the Murals of Bonampak, University of Texas Press, Austin.

Morehart, C. T., Lentz, D. L., and Prufer, K. M. (2005). Wood of the Gods: The ritual use of pine (Pinus spp.) by the ancient lowland Maya. Latin American Antiquity 16: 255-274.

Moyes, H., and Montgomery, S. (2016). Mapping ritual landscapes using Lidar: Cave detection through local relief modeling. Advances in Archaeological Practice 4: 249-267.

Nance, C. R., Whittington, S. L., and Borg, B. E. (2003). Archaeology and Ethnohistory of Iximche, University Press of Florida, Gainesville.

Palka, J. W. (2005). Unconquered Lacandon Maya: Ethnohistory and Archaeology of Indigenous Culture Change, University Press of Florida, Gainesville.

Paris, E. H., Taladoire, E., and Whiting, T. A. (2015). Return to Moxviquil: Form and function in a small Maya city. Ancient Mesoamerica 26: 81-112.

Peruramaki-Brown, M. M. (2014). Neighbourhoods and dispersed/low-density urbanization at Buenavista del Cayo, Belize. Research Reports in Belizean Archaeology 11: 67-79.

Powis, T. (ed.) (2005). New Perspectives on Formative Mesoamerican Cultures, BAR International Series 1377, Archaeopress, Oxford.

Prufer, K. M., and Brady, J. E. (eds.) (2005). Stone Houses and Earth Lords: Maya Religion in the Cave Context, University Press of Colorado, Boulder.

Prufer, K. M., and Thompson, A. E. (2016). Lidar based analyses of anthropogenic landscape alterations as a component of the built environment. Advances in Archaeological Practice 4: 393-409.

Reese-Taylor, K., Hernández, A. A., Esquivel, A. F., Monteleone, K., Uriarte, A., Carr, C., Acuna, H. G., Fernández-Díaz, J. C., Peuramaki-Brown, M., and Dunning, N. (2016). Boots on the ground at Yaxnohcah: Ground-truthing Lidar in a complex tropical landscape. Advances in Archaeological Practice 4: 393-409.

Robin, C. (ed.) (2012). Chan: An Ancient Maya Farming Community, University Press of Florida, Gainesville.

Robin, C. (2013). Everyday Life Matters: Maya Farmers at Chan, University Press of Florida, Gainesville.

Robin, C., Kosakowsky, L., Keller, A., and Meierhoff, J. (2014). Leaders, farmers, and crafters: The relationship between leading households and households across the Chan community. Ancient Mesoamerica 25: 371-387.

Saturno, W. A., Stuart, D., Aveni, A. F., and Rossi, F. (2012). Ancient Maya astronomical tables from Xultun, Guatemala. Science 336: 714-717. 
Scarborough, V. L., and Valdez F. (2003). Heterarchy, Political Economy, and the Ancient Maya: The Three Rivers Region of the East-Central Yucatan Peninsula, University of Arizona Press, Tucson.

Schortman, E., and Ashmore, W. (2012). History, networks, and the quest for power: Ancient political competition in the lower Motagua Valley, Guatemala. Journal of the Royal Anthropological Institute 18: 1-21.

Schortman, E., and Urban, P. (2011). Networks of Power: Political Relationships in the Late Postclassic Naco Valley, Honduras, University Press of Colorado, Boulder.

Sharpe, A. E., and Emery, K. F. (2015). Differential animal use within three Late Classic Maya states: Implications for politics and trade. Journal of Anthropological Archaeology 40: 280-301.

Shaw, J. M. (2008). White Roads of the Yucatan: Changing Social Landscapes of the Yucatec Maya, University of Arizona Press, Tucson.

Shaw, J. M. (ed.) (2015). The Maya of the Cochuah Region: Archaeological and Ethnographic Perspectives on the Northern Lowlands, University of New Mexico Press, Albuquerque.

Sheets, P. (ed.) (2002). Before the Volcano Erupted: The Ancient Ceren Village in Central America, University of Texas Press, Austin.

Smith M. E. (ed.) (2012). The Comparative Archaeology of Complex Societies, Cambridge University Press, Cambridge.

Smith M. L. (2014). The archaeology of urban landscapes. Annual Review of Anthropology 43: 307-323.

Stanley B. W., Stark B. L., Johnston K. L., and Smith M. E. (2012). Urban open spaces in historical perspective: A transdisciplinary typology and analysis. Urban Geography 33: 1089-1117.

Stanley, B. W., Dennehy, T. J., Smith, M. E., Stark, B. L., York, A. M., Cowgill, G. L., Novic, J., and Ek, J. (2016). Service access in pre-modern cities: An exploratory comparison of spatial equity. Journal of Urban History 42: 121-144.

Stanton, T. W., and Magnoni, A. (eds.) (2008). Ruins of the Past: The Use and Perception of Abandoned Structures in the Maya Lowlands, University Press of Colorado, Boulder.

Stark, B. L. (2014). Urban gardens and parks in pre-modern states and empires. Cambridge Archaeological Journal 24: 87-115.

Storey, G. R. (ed.) (2006). Urbanism in the Preindustrial World, University of Alabama Press, Tuscaloosa.

Walker, D. (ed.) (2016). Perspectives on the Ancient Maya of Chetumal Bay, University Press of Florida, Gainesville.

Wells, E. C., and Davis-Salazar, L. (eds.) (2007). Mesoamerican Ritual Economy: Archaeological and Ethnological Perspectives, University Press of Colorado, Boulder.

Yaeger, J., Brown, M. K., and Cap, B. (2016). Locating and dating sites using Lidar survey in a mosaic landscape in western Belize. Advances in Archaeological Practice 4: 339-356. 